\title{
AZ ŐZ [ Capreolus capreolus (L.) 1758] ÉLETKORBECSLÉSI MÓDSZEREINEK VIZSGÁLATA
}

\author{
Marosán Miklós
}

Állattenyésztési, Takarmányozási és Laborállat-tudományi Intézet

Szent István Egyetem, Állatorvos-tudományi Kar

H-1078 Budapest, István u. 2.

\begin{abstract}
MARosÁn M.: A COMPARATIVE STUdy OF DIFFERENT AGE ESTIMATION METHODS AND AGE-RELATED MARKS IN RoE DeER [Capreolus capreolus (L.) 1758]. Hungarian Small Game Bulletin 12: 203-274. http://dx.doi.org/10.17243/mavk.2014.203

Age can be precisely estimated from the number of cement zones in stocks of roe deer living in Hungarian habitats. Growth zones of the cement stock can be assessed also on dental slides; however, it is more exact with histotechnical methods, first of all with the Goldner trichromium, Heidenhain azan and Giemsa dying.

In the case of roe deer, age estimation is not applicable with slide techniques on the basis of secondary dentin, since the prepared dental slides presenting the secondary dentin did not show any sing of age-related layers in the sample of analysis. On the other hand histological examinations can be successfully applied just like in the case of the cementum. Age estimation by tooth wear yields very close, statistically verifiable correlation with the age estimated form cement zones. Crown height of the molars exhibit strong, statistically proven relationship with the age estimated from cement zones, except the $\mathrm{P}_{1}$ teeth. In all the samples the strongest relation appears for the total average of molars. Highly close relation can be observed in the case of $\mathbf{M}_{1}, \mathrm{M}_{2}$ and $\mathrm{M}_{3}$ teeth. Length parameters of $I_{1}$ teeth indicate a statistically verifiable relation with the age estimated from cement zones. The angle of $I_{1}$ teeth and the age estimated from cementum shows no proper relation, consequently this parameter is not indicative of age.

Dry matter content of the lens in bucks is intensive up to the first year of age, becoming statistically negligible in the succeeding years. On the other hand, lens weight of does keeps growing up to approximately 5 years of age.

According to RAJNIK (1977) there is a close, statistically verifiable relation between the estimated ages of does coming from cement zones and from the nasal septum. Examining the nasal septum of does gives appropriate information on age.

On-site age estimation of live roe-deer is an acceptable procedure complying with practical requirements, but the professional experience, training and precision of the person performing the estimation fundamentally determines the reliability of the method.

Considering that in a given case trophy judgement may result in imposing sanctions against a hunter or a person entitled to hunting, the accuracy of this method is not acceptable. According to our study the age estimated from cement zones was only in an average agreement of $37.6 \%$ with age estimation coming from trophy judgement.
\end{abstract}

KULCSSZAVAK: őz, Capreolus capreolus, kor-megállapítási módszerek KEYWORDS: Roe Deer, Capreolus capreolus, age estimation methods,

\section{BEVEZETÉS}

A természetközeli vadállomány szabályozás, okszerü vadgazdálkodás kivitelezésekor az ökológiai és ökonómiai szempontokat is kielégítő vadállomány kialakításához, a vadgazdálkodási tervezéshez, a hivatalos trófeabírálathoz a korbecslési módszerek ismerete szükséges.

Magyarországon az ejtett trófeás nagyvad, így az őzbak ejtésének szakszerüségét a vadászati hatóság állapítja meg a hivatalos trófeabírálat során. Ezt a munkát az 1996. évi LV. törvény a vad védelméről, a vadgazdálkodásról, valamint a vadászatról, a hozzátartozó 
79/2004.(V.4.)FVM rendelet alapján az élőhelyi sajátosságok, a trófea értékmérő tulajdonságok, és a meghatározott életkor szerint végzik. Tehát az ejtés szakszerüségének megítéléséhez az életkor ismerete elengedhetetlenül szükséges. A vadászati hatóság a szakszerütlen ejtést szankcionálja a jogszabály szerint, holott abszolút biztos kor megállapítása csak a fogváltás befejeződéséig, azaz 12 hónapos korig lehetséges (PRIOR, 1968). Egyéves kor felett az életkort biztosan meghatározni nem lehet, csak becsülhetjük a korbecslési módszerek segítségével és egyes korra utaló jegyek figyelembevételével.

\subsection{Célkitüzések}

Kutatásom célja, hogy a korábban jellemzően szubjektív módon, vélekedéssel értékelt korbecslési módszereket és korra utaló bélyegeket megvizsgáljam, és azok megbízhatóságát és jellemzőit egzakt módon matematikai-statisztikai (biometriai) elemzésnek vessem alá. Ennek eredményeképpen a korbecslési módszerek megbízhatósága és pontossága megállapítható, amelynek alapján gyakorlati alkalmazhatóságuk objektív alapokon átgondolható.

Az alábbi vázlatpontokban bemutatom a vizsgálni kívánt problémákat:

- A cementzónák képződése és életkorbecslési felhasználhatóságának vizsgálata;

- A pótdentin képződése és életkorbecslési felhasználhatóságának vizsgálata;

- A fogkopás morfológiájának és életkorbecslési felhasználhatóságának vizsgálata;

- Fogváltás;

- Az élő őz terepi korbecslésének vizsgálata;

- A trófeabírálati korbecslés vizsgálata és a pontatlanság okainak feltárása;

- Az életkorra utaló morfológiai bélyegek vizsgálata.

Munkám során az alábbi kérdésekre kerestem a választ:

- A magyarországi habitatokban élő őz fogának cementállománya mutat-e életkorbecslésre alkalmas rétegzödéseket?

- A magyarországi habitatokban élő őz fogának secundaer dentin állománya képződése során létrehoz-e életkorbecslésre alkalmas zónákat?

- A különböző korbecslési módszerek és korra utaló bélyegek mutatnak-e, és ha mutatnak milyen típusú és mértékü matematikai-statisztikai (biometriai) összefüggéseket?

- Hogyan minősíthetőek a vizsgált korbecslési módszerek és korra utaló bélyegek a gyakorlati vadgazdálkodási, a trófeabírálati hatósági tevékenység és a vadbiológiai kutatás szemszögéböl?

\section{AZ ŐZ KORBECSLÉSI MÓDSZEREINEK ÉS ÉLETKORRA UTALÓ BÉLYEGEINEK SZAKIRODALMI ÁTTEKINTÉSE}

Az őz korbecslésére nagyszámú pontosabb és kevésbé pontos módszert dolgoztak ki. E módszereket a teljesség igénye nélkül az alábbiakban mutatom be.

\subsection{Az élő őz terepi korbecslése}

Az élő őz életkorát testfelépítése, testtájainak arányai, viselkedése, illetve a bak esetében az agancs jellegének figyelembe vételével becsülik.

\subsection{Korbecslés az őz testfelépítése és viselkedése alapján}

Az őzgidát a sutától kisebb testmérete alapján születésük évében könnyen megkülönböztethetjük. A fiatal sutákat az idősebbektől rövidebb fejük, karcsúbb alakjuk alapján különíthetjük el. 
A középkorúak zömökebbek, gömbölydedebbek (SZEDERJEI, 1940b), teltebbek, hát- és hasvonaluk közel párhuzamos (FARAGÓ \& NÁHLIK, 1997). A öreg suták szikárabbak, csontjaik kiállóak, horpaszuk beesett. Az éves bak testalkata hosszúnak tünő, nyaka vékony. A koponya keskeny és rövidebb, mint a kifejlett egyedeké, de a vékony nyak miatt a fej viszonylag nagynak tűnik (SZEDERJEI, 1959). Az életkor előrehaladásával egy ideig nő a testtömeg, erősödik a bak. A nyak vastagabb, és a bak egyre mélyebben hordja a fejét. A testalkat alapján tehát csak a korcsoportok elkülönítése lehetséges.

A fiatal egyed hangadása gyakori, többet riaszt és viselkedése játékos akár kéthároméves korig. Az öregek mozgása, viselkedése megfontolt, óvatos.

\section{AZ ŐZ KORBECSLÉSE AZ AGANCS ALAPJÁN}

Az agancs alapján is lehet az életkorra következtetni, de a korcsoportok elkülönítése ez alapján nagyon bizonytalan (FARAGÓ \& NÁHLIK, 1997).

Az őzgida megszületését követően másfél hónappal kezdi el növeszteni az úgynevezett gidaagancsot, amely decemberre kifejlődik, és januárra hullajtja el (KÖHALMY, 1999).

Az egyéves őzbak nyársas, villás vagy akár hatos agancsot is felrakhat. Az agancstömeg különbsége egyéves korban, már akár három-négyszeres is lehet a gyenge és a jó agancsfejlesztő egyedek esetében (KöHALMY, 1999).

A következő években a különbség a genetikai adottságoknak és a környezeti tényezőknek köszönhetően jóval jelentékenyebb is lehet az azonos korcsoportok között. A fiatal bak agancsának súlypontja annak felső harmadában van (vadásznyelven az erő felül van). A középkorú baknak az agancsa az elágazásnál és a szár koszorú felé eső részének vastagsága hasonló, az ágai hosszúak, hegyesedők. Az öreg bak agancsa általában a koszorúhoz közel a legvastagabb, ágai rövidek, hegyesek.

A koszorú vízszintes síkhoz képesti dőlése is támpontot nyújt a kor becsléséhez. Fiatalon mediális irányba lejtenek (V alak), középkorúaknál vízszintes, öregkorban laterálisan lejt a koszorú síkja (fordított V alak) (SZIDNAI, 1978). SzEDERJEI (1955) szerint a koszorúk szögállása nem utal az életkorra oly mértékben, hogy azt a korbecsléshez érdemben fel lehetne használni. Ennek ellenére ezt a módszert a trófeabírálati életkor meghatározásában jelentős hangsúllyal veszik figyelembe.

BÁN et al. (1986) kimutatták, hogy egyes trófea-értékmérő tulajdonságok, és az általuk tényleges életkornak nevezett hivatalos trófeabírálati kor között statisztikailag igazolható kapcsolat van. Vizsgálataik eredményét az alábbiakban összefoglalva mutatom be, kiegészítve a kritikus korrelációs koefficiens $\left(\mathrm{r}^{*}\right)$ és a determinációs koefficiens $\left(\mathrm{r}^{2}\right)$ értékével, amelyet a korrelációs koefficiens alapján számítottam ki (1. táblázat).

A korrelációs koefficiensek számított értéke minden esetben meghaladta a kritikus korrelációs értéket, így elmondható, hogy a kor és a fenti trófea értékmérő tulajdonságok között szignifikáns kapcsolat van. Az adatok szórása azonban olyan nagy, továbbá a korrelációs koefficiensek és ennek négyzetei a determinációs koefficiensek értékei olyan alacsonyak, hogy egy-egy trófea értékmérő tulajdonság ismeretében az életkor nem becsülhető meg egzakt módon.

A fenti bemutatás alapján belátható, hogy erős megbízhatósággal és éves pontossággal élő őz esetében a vadászterületen csak a születés évében, azaz gida korban tudjuk meghatározni az életkort. Egy éves korban a becslés már bizonytalansági tényezőkkel terhelt, például hatos bakok esetében nem tudjuk biztosan, hogy egy erős egyéves vagy viszonylag gyengébb kétéves példánnyal állunk szemben. Az ennél idősebbek esetében már csak korcsoportba (fiatal, középkorú, öreg) tudjuk az egyedeket elfogadható megbízhatóság mellett besorolni. 
1. táblázat: A kor és a trófea értékmérö tulajdonságok kapcsolata BÁN et al. (1986) nyomán kiegészítve

Table 1. Relationship between age and trophy parameters

\begin{tabular}{lllll}
\hline & $\begin{array}{l}\text { Kor }(\mathbf{x}) \text { és } \\
\text { agancstömeg }(\mathbf{y})\end{array}$ & $\begin{array}{l}\text { Kor }(\mathbf{x}) \text { és } \\
\text { agancstérfogat } \\
(\mathbf{y})\end{array}$ & $\begin{array}{l}\text { Kor }(\mathbf{x}) \text { és } \\
\text { szárhossz }(\mathbf{y})\end{array}$ & $\begin{array}{l}\text { Kor }(\mathbf{x}) \text { és } \\
\text { összpontszám } \\
(\mathbf{y})\end{array}$ \\
\hline mintaelem szám & 8124 & 8124 & 8124 & 8124 \\
\hline $\mathrm{x}$ átlag (év) & 7,33 & 7,33 & 7,33 & 7,33 \\
\hline $\mathrm{y}$ átlag $\left(\mathrm{g}, \mathrm{cm}^{3}, \mathrm{IP}\right)$ & 336,50 & 148,30 & 23,79 & 100,70 \\
\hline $\mathrm{x}$ szórása & 2,23 & 2,23 & 2,23 & 2,23 \\
\hline $\mathrm{y}$ szórása & 60,17 & 35,42 & 2,26 & 18,18 \\
\hline $\begin{array}{l}\mathrm{x} \text { relatív szórása } \\
(\%)\end{array}$ & 30,38 & 30,40 & 30,38 & 30,38 \\
\hline $\begin{array}{l}\text { y relatív szórása } \\
(\%)\end{array}$ & 17,88 & 23,88 & 9,51 & 18,50 \\
\hline $\mathrm{r}$ & 0,38 & 0,33 & 0,25 & 0,36 \\
\hline $\mathrm{r}^{*}(\mathrm{p}=0,05)$ & 0,195 & 0,195 & 0,195 & 0,195 \\
\hline $\mathrm{r}^{2}$ & 0,14 & 0,11 & 0,06 & 0,13 \\
\hline függvény típusa & $\begin{array}{l}\text { másodfokú } \\
\text { parabola }\end{array}$ & $\begin{array}{l}\text { harmadfokú } \\
\text { parabola }\end{array}$ & $\begin{array}{l}\text { harmadfokú } \\
\text { parabola }\end{array}$ & $\begin{array}{l}\text { másodfokú } \\
\text { parabola }\end{array}$ \\
\hline
\end{tabular}

\section{AZ ELEJTETT ŐZ KORBECSLÉSE}

A lőtt vad életkorára csonttani (osteologiai), azon belül koponyatani (craniologiai) és fogtani (odontologiai) jellemzőknek az életkor növekedésével párhuzamosan bekövetkező változásai alapján következtethetünk.

\subsection{Az őz fogazatának jellemzése}

Az őz heterodont (anisodont) fogazatában metsző-, előzáp-, utózápfog és ritkán őzkampó (szemfog) található. A metszőfogak (I, dentes incisivi) nyakalt, sík- vagy sokszor térgörbe fogak, amelyek csak az alsó fogsorban, az állkapocs (mandibula) metszőfogi részén (pars incisivus) lévő fogmedrekben (alveoli) helyeződnek. A felső fogsorban az állközötti csontban (os incisivus) metszőfogak nincsenek, helyettük elszarusodott hámsejtekkel fedett foglemez (lamina dentalis) található (SzÉKY, 1979; FEHÉR, 1980). Összehasonlító anatómiai szempontból az őznek 3-3 metszőfoga van, de ezekhez laterálisan csatlakozik egy-egy morfológiailag és funkcionálisan metszőfogként müködő szemfog is. Tehát funkcionálisan 4-4 metszőfogról beszélhetünk az őz esetében. Elnevezésük mediolaterális irányban a következő:

$$
\begin{array}{ll}
- & \text { fogófog }-\mathrm{I}_{1} \\
\text { - } & \text { belső középfog }-\mathrm{I}_{2} \\
\text { - } & \text { külső középfog }-\mathrm{I}_{3} \\
\text { - } & \text { szegletfog }-\mathrm{I}_{4}
\end{array}
$$

A felső szemfogak ( $\mathrm{C}$, dentes canini) őznél, melyek az özkampó nevet viselik, csak ritkán fejlődnek ki. Amennyiben mégis kifejlődik, a felső fogsorban az állcsont (maxilla) rostralis fogmedrében található. Az állkapocsban, mint szegletmetszőfog $\left(\mathrm{I}_{4}\right)$ található meg. 
Az előzápfogak ( $\mathrm{P}$, dentes praemolares) az alsó és a felső fogsorban mind a két oldalon hármasával helyeződnek, azaz összesen az őz esetében 12 maradó előzápfog fejlődik ki. Az utózápfogak (M, dentes molares) az előzápfogak mögött helyeződnek, számuk ugyananynyi, mint az előzápfogaké. Az utózápfogakat fejlődésük során tejfogak (dentes lactei) nem előzik meg.

Az őz fogképlete:

összehasonlító anatómiai szempontból

$$
\underline{0033}=32
$$

3133

funkcionális anatómiai szempontból

$$
\frac{0033}{4033}=32
$$

ha az őzkampó is kifejlődik

$$
\frac{0133}{4033}=34
$$

\subsubsection{A fogváltás}

Az őz fogainak váltódása SzEDERJEI (1955) szerint 13-14 hónapos korban, FARAGó (1994, 2002) szerint 12-13 hónapos korban, BIEGER (cit.: SzÉKY, 1979) szerint pedig 12 hónapos korban már befejeződik. PRIOR (1968) szerint a maradó fogak kihasadása és a praemolarisok váltódása egy éves kor előtt befejeződik.

Az őznek születéskor 20 tejfoga van. Először a metszőfogak váltódnak mediolaterális sorrendben 8 és 12 hónapos kor között. Ezt követően az előzápfogak apiconuchalis sorrendben 13-14 hónapos korukban váltódnak. Az első utózápfog $\left(\mathrm{M}_{1}, \mathrm{M}^{1}\right)$ 3-4 hónaposan, a második utózápfog $\left(\mathrm{M}_{2}, \mathrm{M}^{2}\right)$ 5-6 hónaposan, a harmadik utózápfog $\left(\mathrm{M}_{3}, \mathrm{M}^{3}\right)$ 11-12 hónapos korban fejlődik ki (SZEDERJEI, 1955).

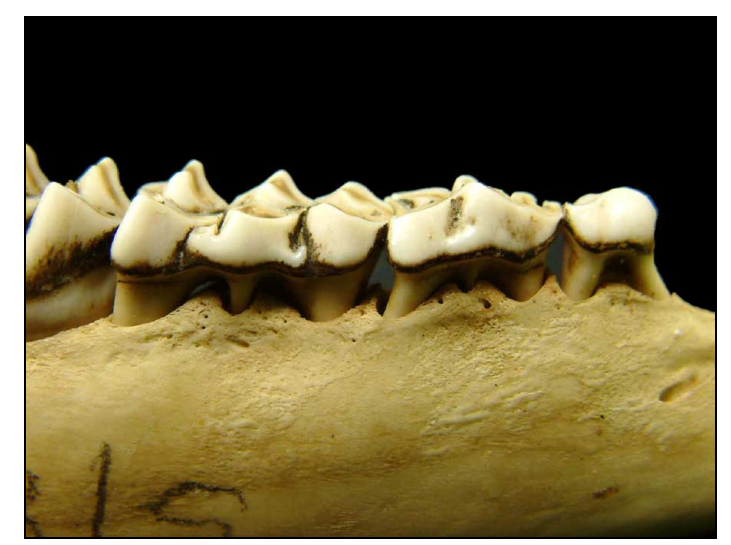

1. ábra: Tej praemolárisok Figure 1: Milk-praemolares

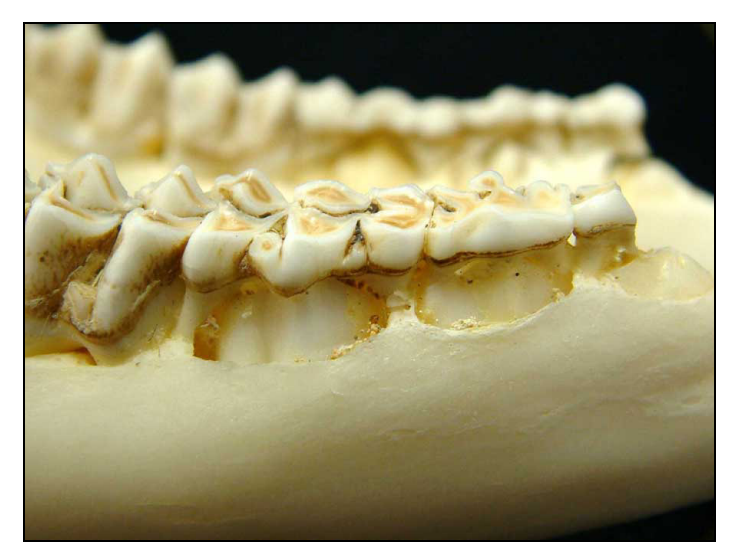

2. ábra. Praemoralisok váltása Figure 2: Changing premolares 


\subsubsection{A fogkopás morfológiája}

A fogkopása alapján történő korbecslés elterjedt eljárás az emlősök életkorbecslése során (MORRIS, 1972; GRANT, 1982, HABERMEHLE, 1985). Az őz esetében is gyakori módszer a fogkopás alapján végzett korbecslés (RIECK, 1970; SZABIK, 1973; WHITE, 1974; AITKEN, 1975; Ashby \& HenRy, 1979; Hrabe \& KoubeK, 1987; Hewison et al., 1999). A hivatásos és a sportvadász, a trófeabíráló és a vadbiológus egyaránt figyelembe veszi, a fogkopás mértékét a korbecsléskor. A fogkopás alapján végzett korbecslést célszerü nem csak egy-egy kiemelt fog vizsgálatával végezni, hanem az egész fogazat kopottságát kell megvizsgálni, hogy a kor minél pontosabban becsülhető legyen. A fogkopás mértékének segítségével végzett korbecslést KÖHALMY (1999) szerint elöször NIETSCHE (1890) alkalmazta a metszőfogak alapján. Később a zápfogak kopottságát is már figyelembe vette NEHRING (1903), majd BIEGER (1933).

A fogkopás alapján elvégzett korbecslés BIEGER (1939, cit. MEÁK \& SzEDERJEI, 1957) szerint 50\%-ban ad pontos eredményt. MEÁK \& SzEDERJEI, (1957) szerint ennek az az oka, hogy egy meghatározott őzpopulációkból származó vizsgálati anyag alapján kidolgozott módszert más területeken adaptálás, kiegészítés nélkül alkalmazzák. Vélelmezhető, hogy ha e módszert a vizsgált állományok adottságainak figyelembe vételével átdolgozzák, a pontosság javítható, akár $70-80 \%$ is lehet.

RIECK (1970) szerint a fogkopás mértékének ismerete érékes információ a kor becslésekor, de a megbízhatósága nem mindig megfelelö.

SzABIK (1973) kétszáz egyedre kiterjedő vizsgálata során a cementállományban lévő zónák alapján becsült korhoz viszonyította a fogkopás alapján becsült kort azt találta, hogy a fiatal (1-4 éves) korosztályok esetében átlagosan egy, az idősebb (5-9 éves) korosztályoknál 2-4 év átlagos eltérés volt megfigyelhető.

AITKEN (1975) tapasztalata szerint a cementzónák alapján becsült kor és a fogkopás alapján becsült kor 63,5\%-ban egyezett meg, és 90,5\%-ban egy éven belül volt eltérés a két módszerrel becsült kor között.

CEDERLUND et al. (1991) ismert korú egyedek vizsgálatával arra a megállapításra jutott, hogy a fogkopás alapján végzett becslés az esetek 68\%-ában ad évre pontos eredményt.

HEVISON et al. (1999) vizsgálata alapján a fogkopás alapján végzett korbecslés $\pm 1,02$ év átlagos eltéréshez vezet, de előfordult -5 és +6 év eltérés is.

Hazánkban az őz fogkopása alapján dolgozott ki korbecslési eljárást SzEDERJEI (1940a; 1955; 1959), amely módszert SZIDNAI (1978) és SZÉKY (1979) kis mértékben módosított.

Az alábbiakban bemutatott összeállítást 7 éves korig AITKEN (1975), 8 éves kor felett Hrabe \& KoubeK (1987) javaslata alapján BlASE (1960) leírását felhasználva, SzEDERJEI (1959) és SzIDNAI (1978) nyomán módosítva, továbbá a trófeabírálatokon megfigyelt korbecslési gyakorlat alapján állítottam össze. A leírást követő szemléltető fotókat a fogcsiszolatok alapján becsült kor utólagos értékelésével készítettem.

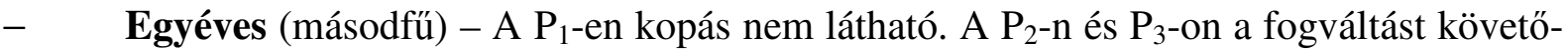
en kopás csak néhány hét esetleg egy hónap múlva alakul ki. Az $\mathrm{M}_{1}$ és $\mathrm{M}_{2}$ fogcsipkéinek élén lekopott a zománc, a feltáródott barna pótdentin már látható. Az $\mathrm{M}_{3}$-nál ugyanez figyelhető meg, de a kisebb mértékü kopás a fog hátulsó oszlopára nem terjed ki (3.ábra).

- $\quad$ Kétéves (harmadfü) - $\mathrm{A}_{1}$-en kopás általában nem látható. A $\mathrm{P}_{2}$ kissé kopott, a kopás hátul erősebb, a pótdentin rajzolata már kivehető. $\mathrm{A}_{3}$ elöl-hátul kopott, a rajzolat is látható. $\mathrm{Az} \mathrm{M}_{1}$-en a csúcsok és az élek nagyon élesek, a külső rajzolat jellemzően háromszögletü, a hasadék kivehető. Az $\mathrm{M}_{2}$ élein a kopás jól látható, a külső rajzolat szélesedik, a hasadék jól érzékelhető. $\mathrm{Az} \mathrm{M}_{3}$ hátulsó csúcsa általában alig kopott (4. ábra). 


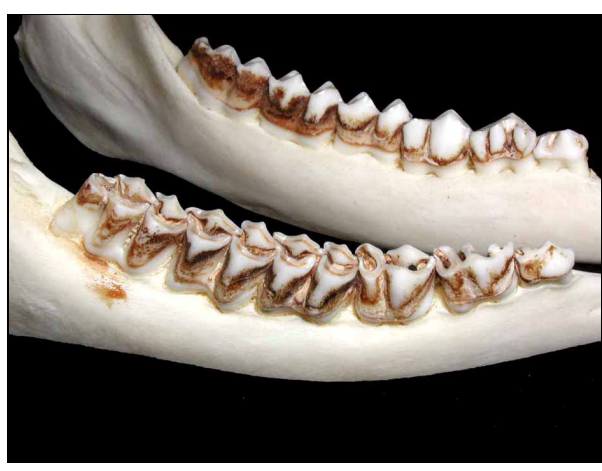

3. ábra: Fogkopás 1 éves korban

Figure 3: Tooth wear at 1 year old age

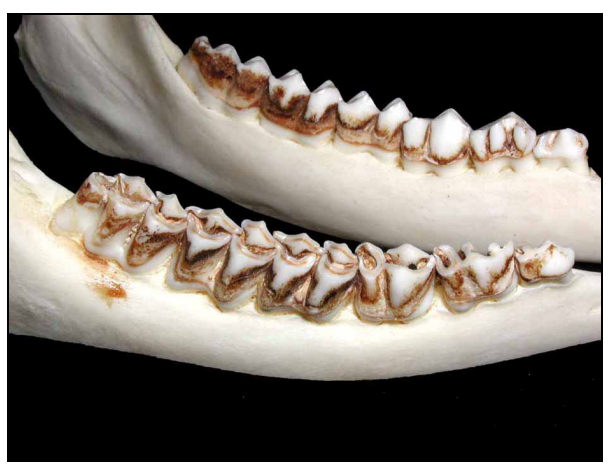

5. ábra: Fogkopás 3 éves korban

Figure 5: Tooth wear at 3 years old age

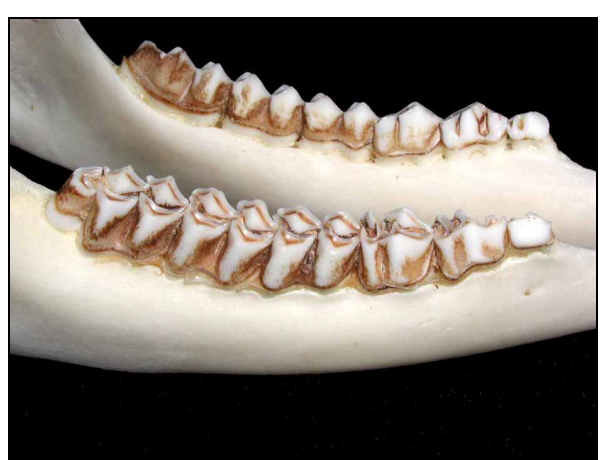

4. ábra: Fogkopás 2 éves korban

Figure 4: Tooth wear at 2 years old age

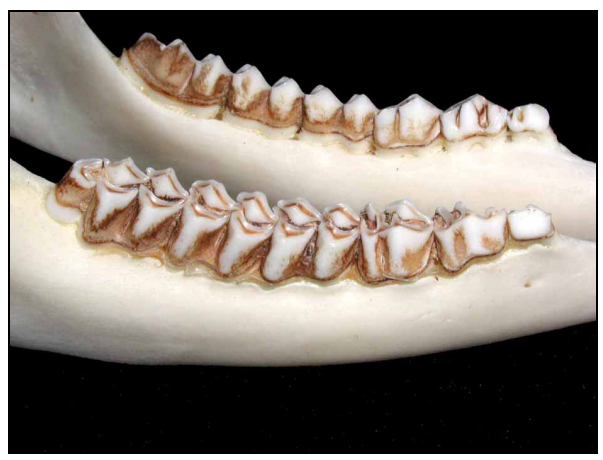

6. ábra: Fogkopás 4 éves korban

Figure 6: Tooth wear at 4 years old age

- Hároméves (negyedfü) - A $\mathrm{P}_{1}$ caudalis része esetenként kopott. A barna pótdentin már esetleg látszik. $\mathrm{A}_{2}$ külső része erősebben kopott, a $\mathrm{P}_{3}$-on határozott kopás látható a rajzolatok majdnem összeérnek. Az $\mathrm{M}_{1}$ rágófelületének külső éle már nem éles, erősen kopott, a barna pótdentin háromszögletü. $\mathrm{Az}_{2}$ rágófelületének külső éle megkopott, a külső rajzolata háromszögletüvé szélesedik. Az $\mathrm{M}_{3}$ hátsó csúcsa alig kopott (5. ábra).

- Négyéves (ötödfü) - $\mathrm{A} \mathrm{P}_{1}$ hátulsó része sokszor már kopott. $\mathrm{A} \mathrm{P}_{2}$ és a $\mathrm{P}_{3}$ erősebben kopott. Az $M_{1}$ külső éle erősebben megkopott, belső éle is határozott kopást mutat. $A z M_{2}$ és az $\mathrm{M}_{3}$ külső éle erősebben megkopott, belső éle is érdemi kopást mutat (6. ábra).

- Ötéves (hatodfü) - A $\mathrm{P}_{1}$ hátulsó része jellemzően már kopott. A $\mathrm{P}_{2}$ külső és belső csúcsai erősen kopottak, a pótdentin a rágólap felületének nagy részén látható. $\mathrm{A}_{3}$ belső csúcsai is nagyon kopottak. A feltáródott barna pótdentin a rágólap felületének nagy részén látható. Az $\mathrm{M}_{1}$ valamennyi csúcsa erősen kopott, a két belső csúcs bőven a rágófelület fölé emelkedik, a zománcredő nagy része elkopott. $\mathrm{Az} \mathrm{M}_{2}$ és az $\mathrm{M}_{3}$ rágófelülete erôsen kopott, de a rágófelületeik élei nem laposak, a belső csúcsok határozottan ki emelkednek, a külső csúcsok kevésbé emelkednek ki, a rajzolat nagyrészt egybefolyik (7. ábra).

- Hat éves (hetedfü) - $\mathrm{A} \mathrm{P}_{1}$ rágófelületének hátulsó része jellemzően erősen kopott. $\mathrm{A} \mathrm{P}_{2}$ rágófelülete erősen kopott, a csúcsok gyakorlatilag lekoptak, a zománcredők még látható. A $\mathrm{P}_{3}$ rágófelülete erősen kopott, de a zománcredő még jól látszik. Az $\mathrm{M}_{1}$ csúcsai teljesen lekoptak, a zománcredő még látszik, de szakadozott. Az $\mathrm{M}_{2}$ csúcsai nem koptak le teljesen, a 
zománcredő még látszik, de szakadozott. $\mathrm{Az} \mathrm{M}_{3}$ rágófelülete lekopott, de a zománcredő még összeér (8. ábra).

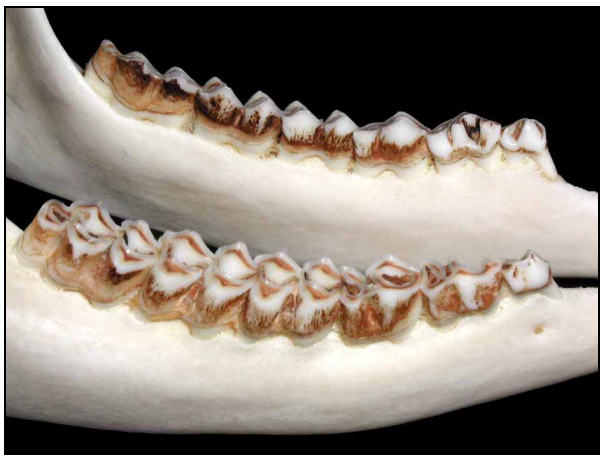

7. ábra: Fogkopás 5 éves korban Figure 7: Tooth wear at 5 years old age

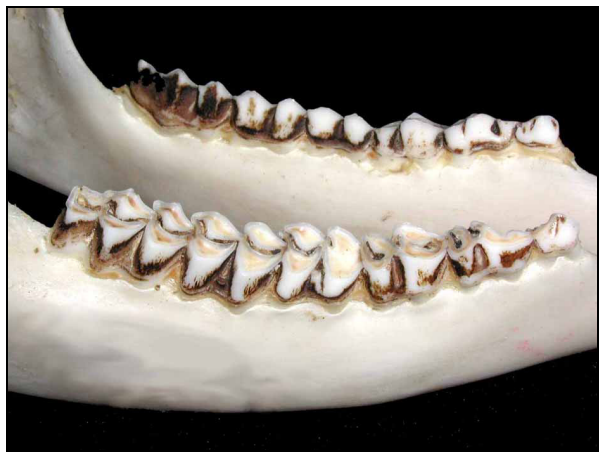

8. ábra: Fogkopás 6 éves korban Figure 8: Tooth wear at 6 years old age

- Hét éves (nyolcadfü) - $\mathrm{A} \mathrm{P}_{1}$ rágófelületének hátulsó része homorúra kopott. $\mathrm{A} \mathrm{P}_{2}$ csúcsai lekoptak, a zománcredők maradványai még láthatók. A $\mathrm{P}_{3}$ csúcsai lekoptak, a zománcredők maradványai szakadozottak, de még láthatóak. Az $\mathrm{M}_{1}$ zománcredőinek maradványai részben már hiányoznak. Az $\mathrm{M}_{2}$ zománcredőinek maradványai már szakadozottak. Az $\mathrm{M}_{3}$ zománcredőinek maradványai szakadozottak, de a zománcredő még összeér (9. ábra).

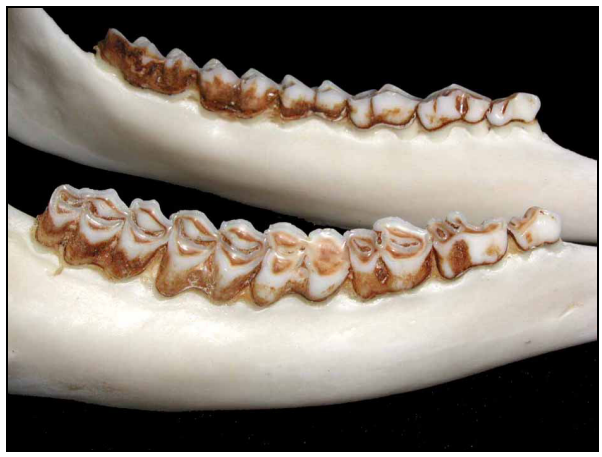

9. ábra: Fogkopás 7 éves korban Figure 9: Tooth wear at 7 years old age

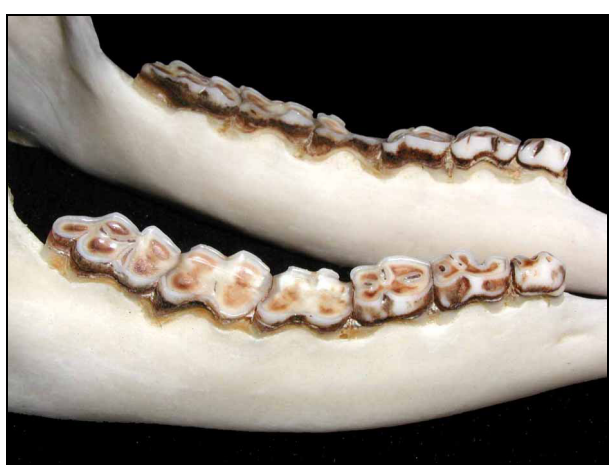

11. ábra: Fogkopás 9 éves korban Figure 11: Tooth wear at 9 years old age

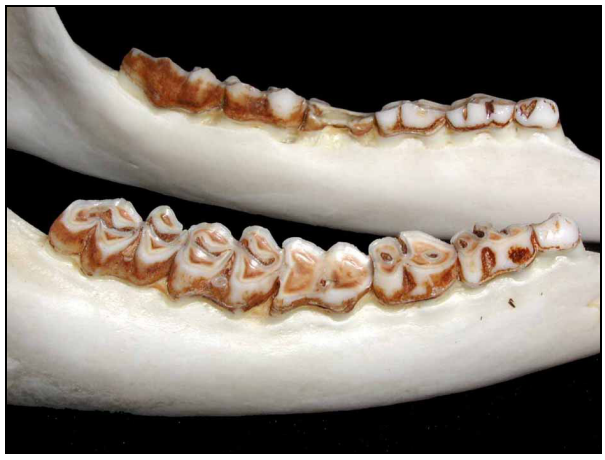

10. ábra: Fogkopás 8 éves korban Figure 10: Tooth wear at 8 years old age

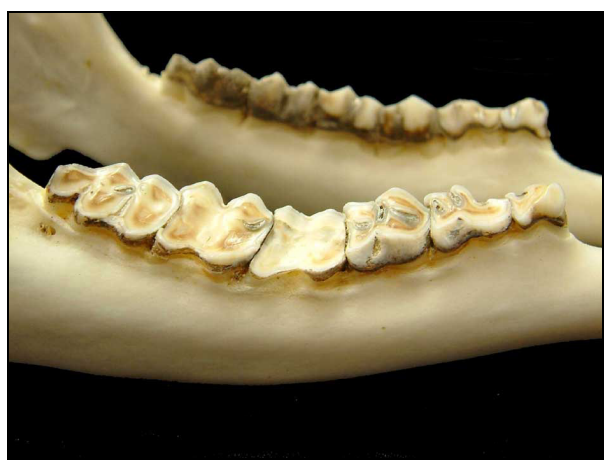

12. ábra: Fogkopás 10 éves korban Figure 12: Tooth wear at 10 years old age 
-Nyolc és kilenc éves (kilenced és tizedfü) - $\mathrm{A} \mathrm{P}_{1}$ rágófelületének hátsó része homorúra kopott. $\mathrm{A} \mathrm{P}_{2}$ rágófelülete úgy lekopott, hogy a zománcredőinek maradványai már alig vehetők ki. A $\mathrm{P}_{3}$ zománcredőinek maradványai eltűntek. Az $\mathrm{M}_{1}$ homorúra kopott zománcredőinek maradványai már hiányoznak, rágófelülete a többi fog rágófelülete alá kopott. Az $\mathrm{M}_{2}$ zománcredőinek maradványai részben, esetleg már teljesen hiányoznak. Az $\mathrm{M}_{3}$ zománcredőinek maradványai szakadozottak, részben már hiányoznak (10-11. ábra).

-Tíz éves és idősebb - A kopottság az összes fog esetében egyre erőteljesebb. Egyes fogrészek, fogak le is töredezhetnek, idővel ki is hullhatnak (12. ábra).

A fogkopáson alapuló korbecslési módszer alkalmazásának hátránya, hogy az eltérő takarmányt felvevő őz fogazata feltételezhetően nem azonos mértékben kopik. A fogkopás mértékét befolyásolhatja a talaj fizikai félesége, mivel a takarmánnyal felvett homok feltehetően jobban koptatja a fogat, mint például az agyag. Mindezek mellett feltételezhető továbbá az is, hogy egyes egyedek fogai jobban kopnak, mint másoké, aminek oka részben a takarmány-felvételi szokásokban (SZABIK, 1973) részben az egyedi fogkeménység különbségében keresendő. Az azonos életkorban eltérő mértékü fogkopottságot fiziológiai, genetikai, etológiai és a környezeti tényezők hatása együttesen alakítja ki.

\subsubsection{A zápfogkoronák külső magassága}

A zápfogak koronái az életkor előrehaladtával folyamatosan kopnak. Ezért a fogkorona magasságok folyamatosan csökkennek.

ASHBY \& HENRY (1979) 56 vegyes ivarú őz vizsgálatakor lineáris regresszióanalízissel értékelte a becsült kor és a mandibuláris $\mathrm{M}_{1}$-es fogak koronamagasságának kapcsolatát. Eredményük szerint a másfél és a hat éves kor közötti értelmezési tartományban a korrelációs koefficiens $(r=-0,86)$ abszolút értéke igen magas. Ez szoros, statisztikailag igazolható kapcsolatot jelent.

CEDERLUND et al. (1991) 71 ismert korú őzből származó mandibula vizsgálatánál, a kor és az $\mathrm{M}_{1}$-es fogak koronamagasságának regressziójánál, a korrelációs koefficiens értéke $\mathrm{r}=-0,66$-nak bizonyult, $\left(\mathrm{r}^{2}=0,44 ; \mathrm{DF}=69 ; \mathrm{P}<0,0001\right)$.

STUBBE \& LOCKOW (cit.: VARGA, 1996) 277 db őz megvizsgálása során az M $M_{1}$-es fogak fogkorona-magassága és a becsült életkor között szoros negatív korrelációt talált. A kapcsolat szorosságát jól jellemzi, a korrelációs koefficiens számított értéke $(\mathrm{r}=-0,855)$. Ennek alapján kiszámítottam a determinációs koefficiens értékét $\left(\mathrm{r}^{2}=0,731\right)$, amelynek százszorosa megmutatja, hogy az életkor változása a vizsgált mintán átlagosan 73,1\%-ban befolyásolta a fogkorona magasságát.

\subsubsection{A metszőfogkoronák kopása}

A táplálék leharapásakor kopnak a metszőfogak koronái. Ezáltal a metszőfogkoronák megfigyelésével szintén tájékozódhatunk az életkorról. STRŐZE (cit.: SZEDERJEI, 1955) erre az alábbi bemutatott módszert dolgozta ki (2. táblázat). 
2. táblázat: A metszőfogak kopása alapján történő korbecslés STRőze (cit.: SZEDERJEI, 1955) nyomán

Table 2. Age estimation from the incisors (after STRÖZE cit.: SZEDERJEI, 1955)

\begin{tabular}{|c|l|}
\hline $\begin{array}{c}\text { Életkor (év) } \\
\text { Age (year) }\end{array}$ & \multicolumn{1}{|c|}{ Az $\mathbf{I}_{1}$ fog jellemzése - Characterization of $I_{1}$} \\
\hline $\mathbf{1}$ & $\mathrm{Az} \mathrm{I}_{1}$ metsző éle erősen domború \\
\hline $\mathbf{2}$ & $\mathrm{Az} \mathrm{I} \mathrm{I}_{1}$ metsző élének laterális része az $\mathrm{I}_{2}$ felé hajlik \\
\hline $\mathbf{3}$ & $\mathrm{Az} \mathrm{I}_{1}$ éle még domború, de kissé hullámos \\
\hline $\mathbf{4}$ & $\mathrm{Az} \mathrm{I}_{1}$ éle még domború, de hullámos \\
\hline $\mathbf{5}$ & $\mathrm{Az} \mathrm{I}_{1}$ éle csaknem egyenes \\
\hline $\mathbf{6}$ & $\mathrm{Az} \mathrm{I}_{1}$ éle egyenes \\
\hline $\mathbf{7}$ & $\mathrm{Az} \mathrm{I}_{1}$ éle a többi I fog metsző éle alá kopott \\
\hline
\end{tabular}

A fenti leírásnál objektívebb adatok nyerhetők, ha a metszőfog koronamagasságát megmérjük.

A gímszarvasnál EIDMANN (1932) végzett ilyen vizsgálatokat, amely során kimutatható kapcsolatot talált a metszőfog $\left(\mathrm{I}_{1}\right)$ koronamagassága és az életkor között. Hazánkban MAROSÁN (1999) 51 db gímszarvas vizsgálatánál statisztikailag igazolható kapcsolatot mutatott ki $\left(\mathrm{r}=-0,751 ; \mathrm{r}^{*}=0,273 ; \mathrm{r}^{2}=0,565 ; \mathrm{P}=0,05 ; \mathrm{DF}=50\right)$.

\subsubsection{A metszőfogkorona és a fognyak aránya}

A metszőfogkorona magassága az életkor emelkedésével a fent említett okok miatt csökken, a fognyak hossza ellenben nő. A növekedés oka, hogy a metszőfog - ha kis mértékben is - egyre jobban kitolódik a fogmederből. Ehhez hozzájárulhat a foggyökércsúcson (apex radicis dentis) jelentősen gyarapodó cementállomány. Az előző folyamatot a fogmederperem esetleges pusztulása tovább fokozhatja. Mindezek miatt a fogkorona és a fognyakhossz hányadosa az életkor növekedésével csökkenést mutat, tehát fordítottan arányos.

Ez a jelenség megfigyelhető a gímszarvasnál is (SZEDERJEI, 1960). MAROSÁN (1999) a gímszarvas életkora és a fogkorona/fognyak arányának korrelációanalízisével szignifikáns kapcsolatot mutatott ki $\left(\mathrm{r}=-0,713 ; \mathrm{r}^{*}=0,273 ; \mathrm{r}^{2}=0,508 ; \mathrm{P}=0,05 ; \mathrm{DF}=50\right)$.

\subsubsection{A metszőfogon kialakuló kopott felület hosszának és a korona nyelvi felületének aránya}

Megfigyeléseim alapján amint gímszarvasnál, úgy őznél is a metszőfogon kialakuló kopott felület hossza a korral növekszik, miközben a kopásmentes rész egyre kisebb lesz. Amennyiben a kopott rész hosszát elosztjuk az egész belső nyelvi koronai felülettel olyan arányszámot (indexet) kapunk, amely utalhat az életkorra. Gímszarvasnál szignifikáns összefüggést mutatott ki $\left(\mathrm{r}=0,598 ; \mathrm{r}^{*}=0,273 ; \mathrm{r}^{2}=0,358 ; \mathrm{P}=0,05 ; \mathrm{DF}=50\right)$ az életkor és az előbb leírt módon képzett arányszám között MAROSÁN (1999). Hasonló vizsgálatokat végzett HELL (1976, cit.: KÖHALMY, 1999) vaddisznónál.

\subsubsection{A metszőfogak szögállása}

Azért, hogy a metszőfogak kopásuk ellenére funkciójukat minél jobban megtarthassák, a kor és a fogkopás mértékének növekedésével az állkapocs alsó (ventralis) síkjával bezárt 
szögük növekszik. Ennek oka, hogy az állkapocs metszöfogi részének (pars incisiva) alsóajki felülete (facies labialis) némileg növekszik. BIEGER (1939 cit.: KÖHALMY, 1999) vizsgálatának eredménye az őznél az életkor és a metszőfogak dőlésszögének kapcsolatát elemzi (3. táblázat).

3. táblázat: A metszőfogak dőlésszögének változása őznél (BIEGER, 1939 cit. KöHALMY, 1999) nyomán

Table 3. The Changing of incisors inclination (after BIEGER,1939 cit. KÖHALMY, 1999)

\begin{tabular}{|c|c|}
\hline $\begin{array}{c}\text { Életkor (év) } \\
\text { Age (year) }\end{array}$ & $\begin{array}{c}\text { Metszőfogak dőlésszöge } \\
\text { Inclination of incisors }\end{array}$ \\
\hline $\mathbf{1}$ & 53 \\
\hline $\mathbf{2}$ & 55 \\
\hline $\mathbf{3}$ & 58 \\
\hline $\mathbf{4}$ & 60 \\
\hline $\mathbf{5}$ & 63 \\
\hline $\mathbf{6}$ & 65 \\
\hline $\mathbf{7}$ & 66 \\
\hline $\mathbf{8}$ & 67 \\
\hline$\geq \mathbf{9}$ & 70 \\
\hline
\end{tabular}

\subsubsection{A zápfogsor hossza}

A kifejlett őz zápfogsorának hossza, az életkor elörehaladtával rövidül. A rövidülés okai SZEDERJEI (1955) szerint:

- Az életkor gyarapodásával szorosabban illeszkednek a fogak egymáshoz;

- A zápfogak ék alakúak, így a korona kopásával a fogsorhossz is csökken;

- A szomszédos fogak gyökerei és fognyakai közötti eredetileg körülbelül 2 mm-es távolság az életkor növekedésével csökken;

- A 3 gyökerü harmadik tejelözápfog $\left(\mathrm{p}_{3}\right)$ hosszabb, mint a maradó harmadik előzápfog $\left(\mathrm{P}_{3}\right)$.

SzUNYOGHY (1963) megállapítása, amely szerint a gímszarvasnál a fogak fogmederből történő kitolódásával a fogsorhossz rövidül, feltehetően az őzre is igaz. Ugyancsak megfigyelhető az öznél is MAROSÁN (1999) gímszarvasra tett megállapítása, miszerint összekopnak a fogak egymás felé tekintő felületei (facies contatctus) és ez is hozzájárul a fogsorhossz rövidüléséhez.

\subsubsection{A foghézag hosszának növekedése}

A foghézag (diasthema), más néven a foghíjas szél (margo interalveolaris) az állkapocs szegletmetszőfoga és az első előzápfoga között húzódó fogmeder mentes csontszegély.

$\mathrm{Az}$ életkor előrehaladása során az emlős fajok egy részénél, egy ideig a diasthema hossza növekvő tendenciát mutat. Ez a jelenség megfigyelhető őznél is. Erre vonatkozó vizsgálatokat végzett AITKEN (1975), de eredményeit csak egy grafikonon mutatja be, sem konkrét adatokat, sem statisztikai értékelést nem közölt. A grafikonjáról annyi mindenesetre leolvasható, hogy a születés évében jelentős diasthema hossznövekedés figyelhető meg, és egyéves kor után a növekedés üteme jelentősen lelassulva folytatódik. 
A gímszarvasnál az életkor elörehaladtával statisztikailag igazolható hossznövekedést talált SZUNYOGHY (1963). MAROSÁN (1999) 48 gímszarvasbika megvizsgálásával az életkor és a foghézaghossz között közepes erösségü statisztikailag igazolható összefüggést talált ( $\mathrm{r}=$ 0,644). Mindezek alapján feltételezhető, hogy e paraméter az őznél is kapcsolatban van az életkorral.

\subsubsection{A fogak növekedési vonalainak vizsgálata}

A cement- és a dentin-állomány gyarapodása során sávokat képez, amelyek száma az életkorral kapcsolatba hozható, s így a cementum és a dentin értékelése különböző mikroszkópos vizsgálattal a kor becslésére felhasználható (FISHER \& MACKANZIE, 1954; KLEVEZAL \& KLEINENBERG, 1967; NAGY \& SZÉKY, 1995).

A fogakban található növekedési vonalak életkorbecslési alkalmazásáról elsőként EIDMANN (1932) számolt be gímszarvassal kapcsolatos közleményében. Később medvefókán (Callorhinus ursinus cynocephalus) vizsgálta SCHEFFER (1950), elefántfókán (Mirounga leonina) LAWs (1952). Azt, hogy jávorszarvas fogainak cementállományban, az életkorra utaló számú sávok, zónák találhatók, elsőként SERGEANT \& PIMLOTT (1959) publikálták. LOW és CowAN (1963) szarvasfélék cement-állománya alapján becsültek kort, és még ugyanebben az évben megjelent MCEVEN (1963) karibu, és MiTCHELL (1963) gímszarvas cementállomány vizsgálatával foglalkozó életkorbecslési cikke. Ezt követően sorozatosan jelentek meg a fogak szövettani szerkezetét értékelő életkorbecslési célú vizsgálatokkal foglalkozó tanulmányok.

Virginiai (fehérfarkú) szarvassal (Odocoileus virginianus) illetve öszvérszarvassal (Odocoileus hemionus) ROBINETTE et al. (1957), WOOD (1962), BRIAN (1966), RANSOM (1966), Gilbert (1966), SOHN (1968), ERICKSON \& SELIGER (1969), LOCKARD (1972), TOMAS \& BANDY (1973), KAY (1974) és RicE (1980) munkái foglalkoztak.

Rénszarvas (Rangifer tarandus) korbecsléssel MILLER (1974) és GORDON (1988) foglalkozott.

Jávorszarvas (Alces alces) korbecsléssel SEVERINGHAUS (1949), WOLFE (1969), KEISS (1969), GASSAWAY et al. (1978) és CUMMING \& EvANS (1980) munkái foglalkoztak.

Gímszarvassal (Cervus elaphus) kapcsolatosan QUIMBY \& GAAB (1957), MiTCHELL, (1967) Lowe (1967), Douglas (1970), Klein et al. (1981), Brown \& ChapMAN (1991), KIERDOF \& BERCHER (1997) és MAROSÁN (1999, 2000, 2001a) publikálták tapasztalatikat.

Szikaszarvassal (Cervus nippon) kapcsolatos korbecslésről UCKERMANN \& SHOLZ (1971), BRIEL (1978) és BARTOS et al. (1984) közöltek adatokat.

Öznél (Capreolus capreolus) végzett, a fog növekedési vonalainak értékelésével is foglalkozó tanulmányt készített PrIOR (1968), BAZIS (1971), ALMASSAN (1972), SZABIK (1973), White (1974), AitKen (1975), Briel (1978), ASHBy \& Henry (1979), Hrabe \& KoubeK (1987), FeleK (1987), CEDERLund et al. (1991), KovÁCs \& FeleK (1991), Hevison et al. (1999) MAROSÁN (2001b, in press) és MAROSÁN \& GERGÁTZ (2001).

Carnivora fajok korbecslését STONEBERG \& JONKEL (1966), GRUE (1976), GRUE \& JENSEN $(1973,1976)$ és HARRIS (1978) vizsgálták más szerzők mellet.

Trópusi fajoknál végzett korbecslésről SPINAGE (1976) számolt be.

A régészeti állattannal kapcsolatos korbecsléssel foglalkozó tanulmányt publikált Castel (1975), MayHew (1978), Coy et al. (1982), Stallibrass (1982), SAVILle \& BeATtie (1983), StAn (1989), Gordon (1993), Monks \& Robert (1993), PiKe-TAy (1991, 1995) és CARTER (1998).

Humán vonatkozásokkal kapcsolatosan többek között CHARLES et al. (1986), CONDON et al. (1986), KVAAL et al. (1996) és SzIKOSSY et al. (2003) publikálták tapasztalataikat. 
Átfogó tanulmányokat Klevezal \& Kleinberg (1967), Grue \& JENSEN (1979), Morris (1972), FANCY (1980), KLEVEZAL (1996) és SigRID et al. (1996) állítottak össze.

\subsubsection{Cementrétegek képződése}

A fogak nyakát és gyökerét cementállomány borítja (ÁBRAHÁM, 1964; HOLLósI, 1995; HusvéTH, 2000; HILlsON \& BOND, 1996 NÉMETH \& L. KISS, 2002). A cementállomány az életkor növekedésével vastagszik (FANCY, 1980, GuZSAL, 1981; HiLlSON, 1986;). Ez a vastagodás a metszőfogak esetében a gyökércsúcsnál, a zápfogak esetében a gyökérívnél és a gyökércsúcsnál a legerősebb. 1980).

A cementum korbecslési célú vizsgálata során három eljárás alkalmazható (FANCY,

Az egyik módszer szerint a zápfogak valamelyikén - általában az $\mathrm{M}_{1}$-en - transzverzális síkban a gyökéríven csiszolatot készítünk, a felületet polírozzuk, s majd sztereomikroszkóp alatt a cementzónák száma alapján becsüljük a kort.

A másik módszer esetében valamelyik zápfog gyökérívén vékony átvilágítható csiszolatot készítünk - megfelelő csiszoló berendezéssel - s a preparátumot labormikroszkóppal értékeljük. A gyakorlatban ez a módszer nem terjedt el.

A harmadik eljárás során a vizsgált fogat - jellemzően az $\mathrm{I}_{1}$-et és az $\mathrm{M}_{1}$-et dekalcinálni kell, majd beágyazni, metszeni és hisztotechnikai eljárással festeni. Ezt követően a metszetet labormikroszkóppal lehet vizsgálni. E három módszer csak technikailag különbözik, mivel ugyanazt a morfológiai képletet értékeli különböző eljárásokkal.

SZABIK (1973) a cementumban megfigyelhető zónák alapján végzett korbecslést tartja a legpontosabb eljárásnak, és összehasonlító vizsgálatainak alapját is ez az eljárás képezi.

AITKEN (1975) ismert korú őzek vizsgálatával, hasonlóan Low \& COWAN (1963) ismert korú karibunál és MiTCHELL $(1963,1967)$ ismert korú gímszarvasnál, végzett vizsgálata során pontos, jól használható korbecslési eljárásnak minősítette a cementállomány fogcsiszolat segítségével történő értékelését, az $\mathrm{M}_{1}$-es fogaknál. Kutatásának eredményeként megállapítja, hogy az őznél a nyári (vegetációs) időszakban vastagabb fehér, sejtdús sáv képződik a cemetumban, míg télen (a vegetációs időszakon kívül), általában januártól egy vékonyabb sötétebb sáv látható.

Egy németországi vizsgálatban BRIEL (1978) az őznél életkorra utaló zónákat a cementállományban mindössze 11 \%-ban talált. Feltételezhető, hogy Magyarországon a kontinentális klíma miatt ez az arány jobb, mint Németországban, ahol az óceáni éghajlat kiegyenlítő hatása jobban érvényesül.

FELEK (1987) szoros összefüggést talált az $\mathrm{M}_{1}$-es fogak dekalcinált metszetein megszámolt cementzónák alapján a valódi kor és becsült kor között.

CEDERLUND et al. (1991) szintén ismert korú őzek vizsgálatával, az $\mathrm{M}_{1}$-es fogak csiszolatain megfigyelhető cementzónák száma alapján végzett korbecslést a fogkopás alapján végzett korbecslésnél pontatlanabbnak találta. Vizsgálatában a valódi korral a cementzónák alapján becsült kor 46\%-ban egyeztett meg, ellenben a fogkopás 68\%-ban mutatott azonosságot.

KovÁCS \& FELEK (1991) a valódi életkor és az $\mathrm{M}_{1}$-es fogak dekalcinált metszeteinek cementzónái alapján becsült kor között szignifikáns kapcsolatot talált $(\mathrm{r}=0,8622 ; \mathrm{n}=9$; $\mathrm{P}<0,001)$.

Hazánk területén gyüjtött mintákban MAROSÁN (1999) gímszarvasnál végzett vizsgálatában 95,28 \%-ban talált olyan korra utaló sávokat a cementumban, amely alapján az életkor becsülhető volt. 


\subsubsection{A fogakban képződő pótdentin}

A fogak használatuk során kopnak. A kopás elöször a fogak rágófelületén (facies occlusialis), a metszőfogaknál a metsző élen, a zápfogaknál a csúcsokon, éleken jelentkezik. Legelőször a zománc kutikula kopik le, azután kezd a zománc is kopni. Amikor a fogzománc lekopik az élekröl, az alatta található dentin ezáltal feltáródik, és közvetlenül érintkezik a szájüregben lévő anyagokkal: nyállal, takarmánnyal. Erre a fog két módon reagál. Az egyik reakció során a primer dentinbe fokozott ásványi anyag beépülés (mineralizáció) következik be, melynek következtében növekszik a feltáródott dentin szilárdsága. A másik reakció, a dentinképző (odontoblast) sejtek pót- (secundaer) dentin képzésbe kezdenek, amivel elsősorban a kopott rész alatt vastagítják meg jelentősen a dentinállományt. A secundaer dentin elöidézi a fogbélüreg (cavum dentis) folyamatos beszükülését is radiális irányú képződése során. A pótdentin képződés élettani szerepe az, hogy a hamar lekopó zománc és primer dentin alatt a fogbélüreg ne táródjon fel, és így a fog fertőzése és gyulladása ne következzen be. A pótdentin képződése során zónákat hoz létre, amelyek száma utalhat az életkorra.

A pótdentin képződést a metszőfogaknál EIDMANN (1932) vizsgálta először gímszarvas esetében. Az $\mathrm{I}_{1}$-es fogak koronájában képződő pótdentin sávok alapján végzett korbecslést alkalmazható eljárásnak találta. A metszőfogkoronában elsőként képződő pótdentin zóna EIDMANN (1932) szerint 10-12 éves, NÁHLIK (1996) szerint már akár 5-6 éves korban le is kophat, ezért ez a módszer e kor után csak hozzávetőleges korbecslésre alkalmas Mivel a zápfogkoronák viszonylag gyorsabban kopnak, ezért a zápfogkoronában képződő pótdentin vizsgálata még kevésbé informatív, mint a metszőfogkoronában képződötteké. Mindezek miatt az őz esetében sem várható, hogy a fogkoronai rész csiszolatainak vizsgálata a gímszarvasénál kedvezőbb eredményeket hoz, de a foggyökerek horizontális metszeteinek vizsgálata - mivel ezen a helyen a fogkopás nem jelentkezik - elképzelhetően értékelhető eredményt nyújt.

KLEVEZAL \& KLEINENBERG (1967) vizsgálata szerint az őz dekalcinált $\mathrm{I}_{1}$-es fogainak horizontális metszetében megfigyelhető secundaer dentin sávok száma megegyezik az egyedek életkorával.

\section{EGYÉB KORBECSLÉSI MÓDSZEREK, ÉS KORRA UTALÓ BÉLYEGEK}

\subsection{A koponyacsontok vastagsága és a varratok elcsontosodásának mértéke}

A koponyacsontok (ossa cranii) vastagsága és a koponyavarratok (sutura cranii) elcsontosodása, ezeken belül elsősorban a homlokcsont (os frontale) vastagsága és a homlokvarrat (sutura frontalis) elcsontosodása alapján a korcsoportok különíthetőek el.

- A fiatal bak homlokcsontja vékony, enyhén áttetsző, a homlokvarrat jól látszik, kiemelkedik a homlokcsont síkjából.

- A középkorú bak homlokcsontja vastagabb, a varrat belesimul a homlokcsont síkjába;

- Az öreg bak homlokcsontja vastag, a varratok alig láthatóak (SzIDNAI, 1978).

\subsection{Az agancstő átmérője és szögállása}

Az agancstő, más néven agancs csap, átmérője az életkorral nő a magassága csökken. Az agancstő fiatal korban medialisan hajlik, középkorú őzbaknál függőlegesen, időskorban laterálisan dől. Az agancstő átméröje és a kor közötti kapcsolatot STUBBE \& LOCKOW (cit.: VARGA, 1996) vizsgálták. Vizsgálatukban viszonylag magas korrelációs koefficienst számítottak $(r=0,691)$. Ha ez alapján kiszámítjuk a determinációs koefficiens értékét $\left(r^{2}=0,477\right)$ 
megkapjuk, hogy az életkor a vizsgált mintában 47,7 \%-ban befolyásolja az agancstő átméröjét. SZEDERJEI (1955) szerint az agancstő átmérőjének mérésén alapuló módszer nem használható korbecslésre, mert előfordulhat, hogy egy jó tulajdonságú egyéves baknak az agancstöve vastagabb, mint egy négy-öt éves gyenge képességüé.

STUBBE \& LOCKOW (cit.: VARGA, 1996) az $\mathrm{M}_{1}$-es fog magassága és az agancstő átmérője, illetve az összes zápfog magassága és az agancstő átmérője segítségével korbecslő nomogramot szerkesztettek. A nomogram pontossága vizsgálatuk szerint $50 \%$-ban évre pontos, 33,8 \%-ban 1 év eltérés, 11,2 \%-ban 2 év eltérés, $5 \%$-ban 3 év eltérés volt. E módszerrel az 1 éves kor nem becsülhető a felülbecslés miatt és a $26 \mathrm{~mm}$-nél nagyobb csapátmérőjű bakok esetében is a valóságosnál magasabb kort mutat. Ez az eljárás ugyan objektív méréseken alapul, pontossága mégsem haladja meg a fogkopás alapján becsült kort.

\subsection{A szívesont hossza}

Az aorta nyílása és a bal kamra között helyezkedik el őznél egy kis méretü elcsontosodó képlet, a szívcsont (os cordis). A szívcsont hossza az őz esetében az életkorral egy ideig növekszik, majd csökkenni kezd. A szakirodalomban két szerző számolt be a szívcsont hosszúsága és az életkor kapcsolatának vizsgálatáról. A közölt életkorhoz tartozó adataik közötti különbség e módszer megbízhatatlanságára utal (KöHALMY, 1999). Az alábbiakban bemutatom MüLLER (1976, cit. KÖHALMY, 1999) szívcsont hosszakra vonatkozó összefoglaló adatait (4. táblázat).

\section{4. táblázat: Az életkor és a szívcsont hosszának kapcsolata} MÜLLER (1976, cit.: KöHALMY, 1999) nyomán

Table 4: The relationship between age and heart-bone lenght

\begin{tabular}{|c|c|}
\hline $\begin{array}{c}\text { Életkor (év) } \\
\text { Age (year) }\end{array}$ & $\begin{array}{c}\text { Szívcsont hossza }(\mathbf{m m}) \\
\text { Lenght of heart-bone }(\mathrm{mm})\end{array}$ \\
\hline 0,5 & 9 \\
\hline $1-2$ & 12 \\
\hline $3-4$ & 13 \\
\hline $5-6$ & 15 \\
\hline $7-8$ & 19 \\
\hline $9-10$ & 21 \\
\hline $11-12$ & 19 \\
\hline$\geq 13$ & 18 \\
\hline
\end{tabular}

\subsection{A szemlencse szárazanyag tartalma}

A szemlencse tömege az emlösök élete során folyamatosan növekszik (MORRIS, 1972). Ennek megfelelően szemlencse száraz tömegét az életkorral kapcsolatba hozták több vadfajnál, például gímszarvasnál és őznél MARINGGELE (1979), mezei nyúlnál BROEKHUIZEN (1971), PÉPIN (1973, 1974), Kovács (1983), Pascal \& Kovács (1983), Kovács \& Heltay (1993), fácánnál NAGY \& PUSKÁs (1977).

MARINGGELE (1979) 35 őz becsült életkora és a szemlencséjük száraz tömegének kapcsolatát vizsgálata. Az alábbiakban bemutatom összefoglaló adatait (5. táblázat). Vizsgálatában megállapítja a szemlencse száraz tömegének növekedését, de adatai statisztikai értékelését nem végezte el. 


\section{5. táblázat: Az őz életkora és a szemlencse száraz tömegének kapcsolata MARINGGELE (1979) nyomán}

Table 5: The relationship between age and dry weight of eye lens

\begin{tabular}{|l|c|}
\hline \multicolumn{1}{|c|}{$\begin{array}{c}\text { Életkor } \\
\text { Age }\end{array}$} & $\begin{array}{c}\text { Szemlencse száraz tömege }(\mathbf{m g}) \\
\text { dry weight of eye lens }(\mathrm{mg})\end{array}$ \\
\hline 1 hónap -1 Month & 120 \\
\hline 1 év - 1 year & 228 \\
\hline $\mathbf{3}$ év - 3 years & 302 \\
\hline 5-7 év -5-7 years & 354 \\
\hline 9-12 év -9-12 years & 383 \\
\hline
\end{tabular}

ANGIBAUlt et al. (1993) 45 ismert korú őzet vizsgált meg. A szemlencsetömegek és a kor kapcsolatát megvizsgálva rendkívül szoros regressziót mutattak ki. A bakok esetében a determinációs koefficiens r=0,939, a sutáknál r=0,936.

\subsection{A pajzsporc csontosodása}

A pajzsporc (cartilago thyreoidea) elcsontosodásán alapuló módszert SCHUMACHER (é.n. cit.: SZEDERJEI, 1955) dolgozta ki. Eszerint a korral nő a pajzsporcban kialakuló elcsontosodott rész, a porcállomány rovására. SzEDERJEI $(1955,1959)$ és MEÁK \& SzEDERJEI (1957) arra a következtetésre jutottak, hogy amennyiben e módszert alkalmazni kívánjuk, úgy az életkor és a pajzsporc elcsontosodásának mértékét populációnként kell megállapítani. Becslésük szerint így akár $60 \%$-os pontosság is elérhető.

\subsection{A rágóizom árka}

Az állkapocs ágának (ramus madibulae) külső felületén (facies lateralis) található meg a külső rágóizom (musculus masater) tapadására szolgáló árok, a rágóizom árka (fossa masaterica) (FEHÉR, 1980). Egyes vélemények (KÖHALMY, 1999) szerint a rágóizom árka és az állkapcsi szöglet (angulus mandibulae) érdessége, rajzolata, kiemelkedése alkalmas lehet korbecslésre.

Korábbi megfigyeléseim (MAROSÁN, 1999) a gímszarvasnál ezt nem támasztják alá. A szarvas esetében, az individuális adottságok dominálása elfedi a korra utaló viszonylagos változásokat.

\subsection{A trófeabírálati korbecslés}

A hivatásos trófeabírálaton a korbecslést a vadászati hatóság szakemberei az alábbi korra utaló bélyegek figyelembe vételével állapítják meg:

- Az agancs összképe (fejlődőképesség, kulmináció, visszarakás);

- A koszorú és az agancstő dőlése;

- A koponyacsontok vastagsága és a koponyavarratok elcsontosodása;

- Az orrsövényporc elcsontosodása;

- A fogkopás (amennyiben a fogsor rendelkezésre áll!). 
KOVÁCS \& FELEK (1991) 7 hivatásszerüen trófeabírálattal foglalkozó személyt kértek fel, hogy ismert korú őz trófeákon korbecslést végezzenek. A becslések adatai nem mutattak statisztikailag igazolható kapcsolatot a tényleges korral. Mindössze 14\%-os volt az egyezés, és 86\%-ban tértek el egymástól a becslések. A túlbecslések domináltak nagyobb mértékben, alul becslés alig fordult elő. A vizsgálat tapasztalatai szerint nyolcéves túlbecslés is előfordult. És mindössze 2 szakember becsülte a kort pontosan.

\subsection{A RAJNIK-módszer}

Az orrsövény (septum nasi) caudalisan csontos (septum nasi osseum), rostralisan porcos (cartilago septi nasi) részből áll (FEHÉR, 1980).

RAJNIK (1977) életkorbecslési módszere azon a felismerésen alapul, hogy a korral a porcos rész fokozatosan csontosodik el. E módszer szerint, az elcsontosodott orrsövény hoszszának az orrcsont (os nasale) hosszához viszonyított arányából következtethetünk a korra. A módszer fö hibája, hogy az orrsövény csontos része apicalisan zegzugos rajzolatot mutat, így csak szubjektív értékelésre van lehetőségünk (IFF, 1978, cit.: KÖHALMY, 1999).

\section{ANYAG ÉS MÓDSZER}

\subsection{A mintagyüjtési területek élőhelyi jellemzői}

A mintaterületek élőhelyi jellemzőit MAROSI \& SOMOGYI (1990) alapján állítottam össze.

\section{Békés megyei mintaterület}

A Békés megyei vizsgálatok során Békési-sík kistáj területéről gyüjtöttük a vizsgálati mintát. A kistáj földrajzi értelemben lösszel és agyaggal fedett hordalékkúp síkság. Éghajlata meleg, illetve mérsékelten meleg és száraz. Az évi napfénytartam összege 2000 óra, a középhömérséklet $10,2-10,4{ }^{\circ} \mathrm{C}$, a vegetációs időszak átlaghőmérséklete $17,1-17,3{ }^{\circ} \mathrm{C}$, a fagymentes napok száma 194 körül ingadozik. A csapadékösszeg 550-570 mm között változik, a vegetációs idöszak csapadékösszege 320-330 mm közötti. Az évi hóborítottság időtartama jellemzően 31-34 nap. A kistáj legjellemzőbb talajtípusa a löszön képződött alföldi mészlepedékes csernozjom, kisebb arányban található a területen réti csernozjom és szikesek talajok (réti szolonyec, sztyepesedő réti szolonyec és szolonyeces réti talaj). A talajok mechanikai összetétele vályog és agyagos-vályog. A természetes növénytakarót elsősorban a tatárjuharos lösztölgyesek, a pusztai tölgyesek és a sziki tölgyesek jellemezték. Jelenleg az erdőmüvelés alá vont területeken főként fiatal- és középkorú, fenyőerdőket találunk. A terület 86,4\%-a szántóföld, 2,0\%-a erdő, 3,2\%-a belterület, a rét-legelö aránya 7,3\%, a kerté és a szőlöé $0,7 \%$.

\section{Győr-Moson-Sopron megyei mintaterület}

A Győr-Moson-Sopron megyei mintagyüjtést a Lajta-Hanság Rt üzemi vadászterületein végeztem. A gyüjtéseket földrajzi értelemben a Mosoni-síkon és a Hanságban végeztem.

A Mosoni-sík magasártéri hordalékkúp síkság. Éghajlata mérsékelten hűvös és száraz. Az évi napfénytartam összege 1900 óra, a középhőmérséklet 9,5-10,0 ${ }^{\circ} \mathrm{C}$, a vegetációs időszak átlaghőmérséklete 16,0-16,5 ${ }^{\circ} \mathrm{C}$, a fagymentes napok száma 182-185 között ingadozik. A csapadékösszeg 580-600 mm között változik, a vegetációs időszak csapadékösszege 330-340 mm 
közötti. Az évi hóborítottság időtartama jellemzően 35-45 nap. A kistáj legjellemzőbb talajtípusa a löszös üledéken képződött csernozjom, kisebb arányban található a területen mészlepedékes csernozjom. E talajok vályog mechanikai összetételüek. A Mosoni-Duna és a Lajta közelében réti- és réti öntéstalajok találhatóak, mechanikai összetételük vályog és agyagos vályog. A természetes növénytakarót elsősorban a füzligetek, a égerligetek, a keményfaligetek, a gyertyános-kocsányos tölgyesek, illetve a szárazabb területeken a gyöngyvirágos tölgyesek jellemezték. Az erdőmüvelés alá vont területeken fiatal- és középkorú, kemény- és lágy lombos fafajok a jellemzőek. A terület 85,3\%-a szántóföld, 6,1\%-a erdő, 6,0\%-a belterület, a kert, a szőlő és a rét-legelö aránya $0,7 \%$.

A Hanság földrajzi értelemben alacsonyártéri agyaggal, iszappal, tőzeggel fedett síkság. Éghajlata mérsékelten hűvös és mérsékelten száraz. Az évi napfénytartam összege 19001950 óra, a középhőmérséklet $10,0{ }^{\circ} \mathrm{C}$, a vegetációs időszak átlaghőmérséklete $16,0{ }^{\circ} \mathrm{C}$, a fagymentes napok száma 185 körül ingadozik. A csapadékösszeg 590-630 mm között változik, a vegetációs időszak csapadékösszege 350-360 mm közötti. Az évi hóborítottság időtartama jellemzően 40-42 nap. A kistájra réti- és a réti öntéstalajok jellemzőek. A talajok agyagos vályog mechanikai összetételüek. A természetes növénytakarót égeres láperdők, nyírláperdők, zsombékosok mocsárrétek jellemezték. Az erdőgazdaságilag hasznosított a területeken fiatal lágylombos fajok, elsősorban nemesnyárasok fordulnak elő. A terület 57,9\%-a szántóföld, 14,4\%-a erdő, 1,5\%-a belterület, a rét-legelő 9,1\%, a kert aránya $0,3 \%$.

\section{Tolna megyei mintaterület}

A Tolna megyei vizsgálatok során Közép-Mezőföld kistáj területéről gyüjtöttük a vizsgálati mintát. A kistáj földrajzi értelemben lösszel fedett hordalékkúp síkság. Éghajlata mérsékelten meleg és mérsékelten száraz. Az évi napfénytartam összege 2000-2050 óra, a középhőmérséklet $9,8-10,3{ }^{\circ} \mathrm{C}$, a vegetációs időszak átlaghőmérséklete $16,1-17{ }^{\circ} \mathrm{C}$, a fagymentes napok száma 186-207 között ingadozik. A csapadékösszeg 550-600 mm között változik, a vegetációs időszak csapadékösszege 320-340 mm közötti. Az évi hóborítottság időtartama jellemzően 30-32 nap. A kistáj legjellemzőbb talajtípusa a löszön képződött mészlepedékes csernozjom, jóval kisebb arányban található a területen réti csernozjom, barnaföld, csernozjom barna erdötalaj, réti szolonyec, réti öntés és humuszos homoktalaj is. A talajok vályog mechanikai összetételüek. A természetes növénytakarót elsősorban a tatárjuharos löszpusztai tölgyesek, a cseres tölgyesek, a tölgy-kőris-szil ligeterdők és a füz-nyár-égerligetek jellemezték. Jelenleg az erdőművelés alá vont területeken fiatal- és középkorú, kemény- és lágy lombos fafajok a jellemzőek, a fenyők aránya jóval szerényebb. A terület 84,2\%-a szántóföld, 5,6\%-a erdő, 5,4\%a belterület, a kert, a szőlő és a rét-legelő aránya $4,1 \%$.

\subsection{A vizsgálati anyag}

A vizsgálati anyagot, a begyüjtött őzállkapcsok, fejek illetve az úgynevezett kiskoponya lefürészelése után megmaradt csonkolt koponyák alkotják, a hozzájuk tartozó legfontosabb adatokkal. A 636 egyedböl származó mintánál a mandibula mellé a csonkolt koponyát is sikerült 68 esetben beszereznem. Az állkapcsokat és a koponyákat az ország több élőhelyéről (Tolna, Győr-Moson-Sopron és Békés megye) gyüjtöttem be hivatásos vadászok, illetve vadászati felügyelök segítségével 1998 és 2004 között. Az alábbiakban bemutatom a gyüjtött anyag származási helyét az elejtés időpontját és a darabszámokat (6. táblázat). 
6. táblázat: A vizsgálati anyagok származási helyei, elejtési időpontjai és darabszámai Table 6. The collections place, time and number of samples

\begin{tabular}{|l|c|c|}
\hline $\begin{array}{l}\text { Elejtés helye (megye) } \\
\text { Place of samples (county) }\end{array}$ & $\begin{array}{c}\text { Elejtési időpont (év) } \\
\text { Time of samples }\end{array}$ & $\begin{array}{c}\text { Egyedszám (db) } \\
\text { Number of samples }\end{array}$ \\
\hline Békés & $1998-1999$ & 56 \\
\hline Tolna & $2000-2004$ & 494 \\
\hline Győr-Moson-Sopron & 2004 & 86 \\
\hline Összesen - Total & & $\mathbf{6 3 6}$ \\
\hline
\end{tabular}

A Tolna-megyei mintából 356 példány bak és 138 példány suta volt. Békés és GyőrMoson-Sopron megyei minták csak bakokat tartalmaztak.

\subsection{A vizsgálat módszerei}

Munkám során körülbelül 66.700. adatot vettem fel és értékeltem. A korbecslési módszereket és korra utaló bélyegeket, illetve a közöttük lévő kapcsolatokat matematikai-statisztikai (biometriai) módszerek segítségével vizsgáltam meg (DAPSON, 1980; F. NAGY, 1994; BARÁTH, 1996; VARGHA, 2000). Az alkalmazott módszerek a következők voltak:

- Regresszióanalízis;

- Korrelációanalízis;

- Determinációs koefficiens számítás;

- Fischer-féle F-próba;

- Egymintás t-próba;

- Egymintás z-próba.

Az alábbiakban röviden bemutatom a megvizsgált korbecslési módszereket és a korra utaló bélyegeket, amelyeket a vizsgálat során alkalmaztam. A bemutatás során nem térek ki a szakirodalmi áttekintésben már bemutatott módszerek részletezésére, e helyett a vizsgálatok gyakorlati kivitelezését és mérési módszereit ismertetem.

\subsubsection{A fogkopás alapján végzett korbecslés}

A fogkopás alapján végzett korbecslést AITKEN (1975), BLASE (1960), SZEDERJEI (1959) és SZIDNAI (1978) nyomán módosított, továbbá a trófeabírálatokon megfigyelt korbecslési gyakorlat alapján állítottam össze, a vizsgálatokat: 2.3.3. „A fogkopás morfológiája” címü alfejezetben leírtak szerint végeztem.

\subsubsection{A zápfogak külső magassága}

A zápfogkoronák magasságát a fogkorona külső csipkéjétől és a korona külső felületének zománccal borított rész aljáig mértem, szemben több szerző (AITKEN, 1975; AsHBY \& HENRY, 1979; és mások) módszerével, akik az íny vonaláig mérték a fogkorona magasságot. A méréseket tized mm pontossággal végeztem, digitális tolómérő segítségével. Ha a fogkorona nem nőtt ki teljesen az állkapocsból, úgy csak az alveolus pereméig mértem.

Az előzápfogaknál egy, az utózápfogaknál kettő, az utolsó utózápfognál három fogkorona-magassági adat felvételére került sor. Az utózápfogaknál a két illetve három csúcs átlagmagasságát vettem alapul. 


\subsubsection{A metszőfogak hosszúsági paramétereinek vizsgálata}

A metszőfogak esetében az alábbi adatokat vettem fel:

- A metszőfog korona ajaki felületének (facies labialis) hosszúságát, amelyet a fogkorona aljától, a metszőélig mértem;

- A metszőfog korona egész belső felületének (facies linquinalis) hosszúságát a nyelvi felületen lévő koronarész teljes hosszának mérésével állapítottam meg.

- A metszőfogak belső felületének kopottságát az érintett rész hosszúságának lemérésével oldottam meg;

- A fognyak hosszúságát, a fogmeder perem szélétől a fogkorona aljáig mértem;

A fenti módszerekkel felvett adatok alapján kiszámoltam, az $\mathrm{I}_{1}$-es fogak fogkorona/fognyak hosszúságának az arányát, melyet a két mért adat hányadosa ad meg. A metszőfogakon lévő kopott rész és a belső felület hosszúságának az arányát szintén a mért adatpár hányadosa adja meg.

\subsubsection{A metszőfogak szögállása}

Az $\mathrm{I}_{1}$-es fogak szögállásának vizsgálatát az alábbi síkgeometriai grafikus módszerrel végeztem el:

1. A fél állkapcsot a mediális oldalával egy papírlapra fektettem;

2. Felülröl merőlegesen az állkapocsra nézve az angulus mandibulae-től apicalisan az incisura vasorum facialium alatt a papírlapra elhelyeztem egy pontot (A);

3. A foramen mentale és a symphysis mandibulae caudalis része között ventralisan jelöltem be a következő pontot (B);

4. A fogófoggal $\left(\mathrm{I}_{1}\right)$ párhuzamba állítottam egy vonalzót és a fogófog tengelyének síkjában egy egyenes vonalat húztam;

5. Az állkapocs elvételét követően az A és B ponton áthaladó egyenest húztam;

6. A két egyenes által bezárt, a fogófog labialis oldalán lévő szög nagyságát szögmérővel megmértem;

7. Ha eltérés volt a két $\mathrm{I}_{1}$-es fog szögállása között, akkor azt átlagoltam, kivéve, ha az egyik helyeződése abnormális volt, olyankor csak a normális $\mathrm{I}_{1}$ szögállását vettem figyelembe;

8. Az így kapott szög a metszőfog szögállását mutató szög.

\subsubsection{A fogsor hossza}

A fogsor hosszát az első mandibuláris előzápfog $\left(\mathrm{P}_{1},\right)$ elülső fogmedrének szélétől, az utolsó utózápfog $\left(\mathrm{M}_{3}\right)$ hátulsó fogmedrének széléig mértem. A vizsgálatok során a jobb és a baloldali fogsorhosszokat egyaránt lemértem, s átlagolásával számítottam ki az egyedre jellemző fogsorhossz értékét.

\subsubsection{A foghézag hossza}

A foghézag hossza az állkapocs szegletfog $\left(\mathrm{C}\right.$ vagy $\left.\mathrm{I}_{4}\right)$ medrének hátulsó peremétől az első előzápfog $\left(\mathrm{P}_{1}\right)$ fogmedrének elülső végéig tart. A távolságát tolómérővel, tizedmilliméter pontossággal mértem, s a jobb és bal oldali fogsorhossz értékeit átlagoltam. 


\subsubsection{A szemlencsetömeg vizsgálata}

A szemlencse vizsgálatát a következők szerint végeztem. Első lépésben szikével bemetszést készítettem a szaruhártyán, majd a hüvelyk-, vagy mutatóujjal az orbita felől nyomást gyakoroltam a szemhólyagra, aminek következtében a bemetszésen keresztuil a szemlencse az üvegtesttel együtt kinyomódik a szemből (13-15. ábra). A szemlencséről ezt követően el kell távolítani az üvegtest maradványait. A szemlencse fixálására 10\%-os neutralizált formaldehidet használtam. Amikor a szemlencséket boncteremben távolítottam el, a fixálást szövetmintagyüjtő kazettában végeztem. A szabadterületi gyüjtések során a szemlencséket egyedileg $50 \mathrm{~cm}^{3}$-es gyógyszeres üvegekbe helyezem el, és a fixálás is azokban végeztem.

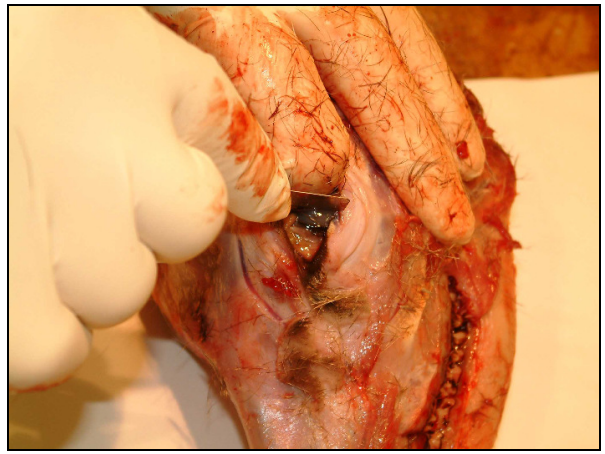

13. ábra: Szemlencse előkészítés 1.

Figure 13: Preparation method of eye lens

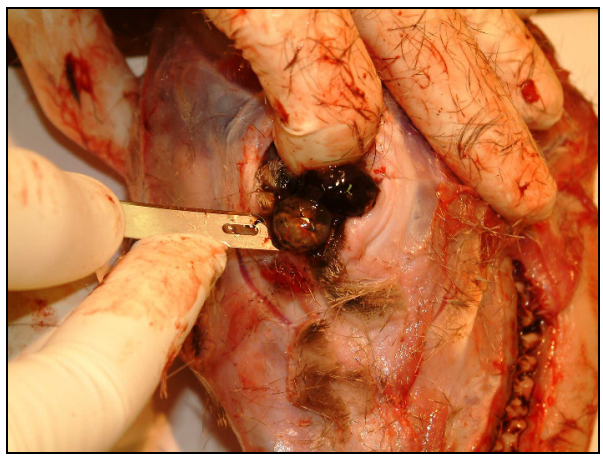

14. ábra: Szemlencse előkészítés 2.

Figure 14: Preparation method of eye lens

A fixálást követően a szemlencséket papírvattán szikkasztottuk, s majd tömegüket analitikai gyorsmérlegen lemértük. A feldolgozás során az így kapott tömegeket, nedves tömeg-ként neveztem meg. Ezután a szemlencséket 48 órán keresztül $60{ }^{\circ} \mathrm{C}$-on szárítószekrényben szárítottuk, s majd tömegüket lemértük. Ez követően mintákat $105{ }^{\circ} \mathrm{C}$-on szárítottuk tovább, 24 órán keresztül, s majd tömegüket ismételten lemértük. Az eljárást LORD (1959) eredeti módszere szerint végeztem azzal a különbséggel, hogy a tömegeket nedvesen, és $60{ }^{\circ} \mathrm{C}$ os szárítást követően is lemértem, és a mért adatokat rögzítettem, s majd feldolgoztam.

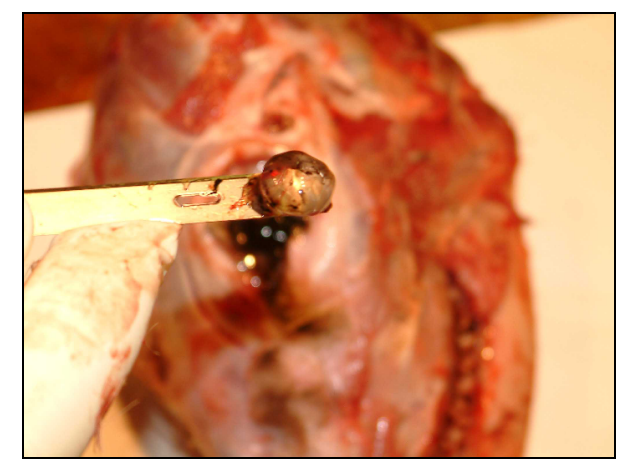

15. ábra Szemlencse előkészítés 3. Figure 15: Preparation method of eye lens 


\subsubsection{A cementállomány vizsgálata}

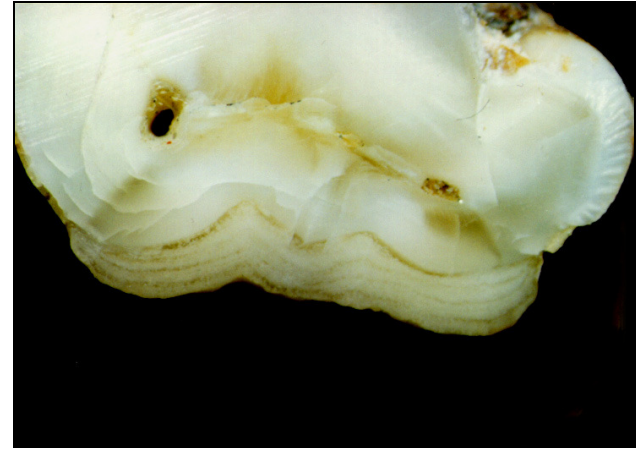

16. ábra: $A z M_{1}$-es fog gyökérívének csiszolata 4 éves őzbaknál (20x)

Figure 16: Cement layers in $\mathrm{M}_{1}$ teeth transversal section at 4 years old aged roe deer buck $(20 \times)$

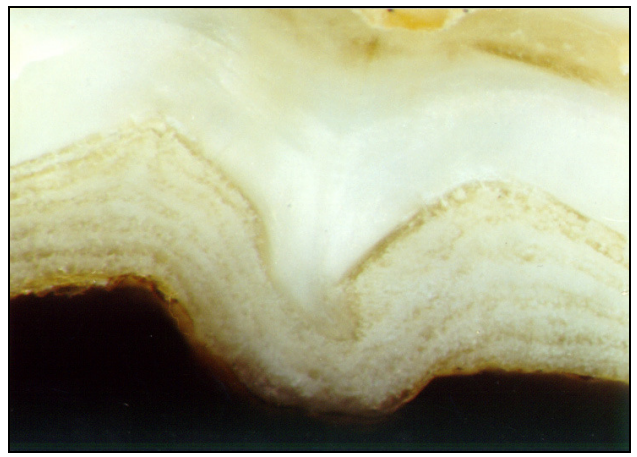

17. ábra: Az $M_{1}$-es fog gyökérívének csiszolata 7 éves őzbaknál (40x)

Figure 17: Cement layers in $\mathrm{M}_{1}$ teeth transversal section at 7 years old aged roe deer buck $(40 \times)$

A cementállomány vizsgálatát Mitchell (1963, 1967) és AitKen (1975) leírása alapján, de néhány pontban módosítva végeztem el. Ennek során korábbi gímszarvasnál és őznél végzett vizsgálataim (MAROSÁN, 1999; 2000, 2001a, 2001b) tapasztalatait adaptáltam.

A csiszolatokat a következő technikával készítettem: Az állkapocsban vagy az állcsontban lévő fogakat oly módon emeltem ki, hogy fúrógépbe fogott körfürészlap segítségével, a laterális oldalon, a csonton bevágásokat végeztem. A kiemelendő fog előtt és mögött transzverzálisan kimartam a fogmedrek közötti széleket (margo interalveolaria), és közvetlenül a foggyökerektől laterálisan és azokkal párhuzamosan is készítettem bemetszést, továbbá a gyökércsúcsok alatt az állkapocs esetében, illetve a gyökércsúcsok felett az állcsont esetében horizontálisan végeztem bemetszést. Ezt követően a csontlemezeket egy kiélezett csavarhúzó segítségével lepattintottam és a fogakat a gyökér felöl kitoltam az alveolusból. Az így kiszabadított fogakat hatvanas szemcsefinomságú csiszolótárcsával transzverzálisan a gyökérív közepéig, vagy majdnem a közepéig lecsiszoltam, majd a megmaradt foggyökér csúcsát is lecsiszoltam. A lecsiszolt felületeket 200-as, 600-as, 1000-es és végül 1200-as szemcsefinomságú vizes szilíciumkarbid csiszolópapíron políroztam, végül vászon polírozó tárcsával tovább finomítottam a felületeket. A végső finomítás elvégzését kipróbáltam oly módon is, hogy a fogat a vizes csiszolópapírok után rajzlapon is körkörös mozdulatokkal dörzsöltem, így ugyanolyan jól vizsgálható preparátumokat kaptam, mint amilyeneket korábban a vászon polírozó tárcsa segítségével készítettem. A munkám során, amikor a preparátumokról nem készítettem fotót kipróbáltam, hogy lehetséges-e a végső finomító polírozás esetleges elhagyása. A tapasztalataim azt mutatták, hogy ha az eredeti csiszolópapír sorozatot 400-as, 800as, 1400-as és végül 2000-esre cserélve alkalmazom, akkor a végső finomító polírozás teljes egészében elhagyható, és a preparátumok értékelhetősége ugyanolyan jó maradt.

A foggyökér horizontális csiszolatait úgy készítettem, hogy ne csak a cementet, hanem a dentint is föltárjam, mert csak így biztosított, hogy az összes cementzóna megfigyelhető. Arra is ügyelni kell, hogy a fenti szempontok teljesülése mellett a gyökércsúcsból minél kisebb rész kerüljön eltávolításra, mert a cementum rétegződése a gyökércsúcshoz közelebb fokozottabb. Mind a transzverzális, mind a horizontális csiszolatokon a fehér zónák száma adja az őz korát években kifejezve (AITKEN, 1975). A fürészeléshez és a csiszolótárcsás müveletekhez egy $650 \mathrm{~W}$ névleges teljesítményü $3000 \mathrm{~min}^{-1}$ fordulatszámú, pótfogantyús (előtétmarkolatos) fúrógépet használtam. Az állkapcsokat, az állcsontokat és a fogakat olyan satuba rögzítettem, amelynek pofáját előzetesen gumival burkoltam. A munka során fültokot és por- 
maszkot használtam. A fogcsiszolatokat Zeiss SM-20, Zeiss SV-11 és Leica MZ-7 5 felső megvilágítású sztereó mikroszkópokkal vizsgáltam (16-17. ábra).

\subsubsection{A pótdentin vizsgálata}

A pót (secundaer) dentin vizsgálatához szükséges preparátum elkészítését az alábbiakban mutatom be.

A pótdentin vizsgálatához a fogófogat $\left(\mathrm{I}_{1}\right)$ használtam fel. Mivel ez a fog viszonylag kis méretü és törékeny, ezért nem vettem ki a vizsgálat során a fogmederből, hanem az állkapocsban hagytam és az állkapocs pars incisiva-ját, a fogmedret - a benne lévő fogmederhártyával (periodontium), Sharpey-rostokkal - mint természetes ágyazati anyagot használtam. A metszőfogi részt a foghézagnál lefürészeltem, majd satuba fogva a fogmedret a fogófoggal együtt a fogbélüreg (cavum pulpae) közepéig lecsiszoltam, és utána políroztam a cementállomány vizsgálatánál leírtak szerint. Nehézséget a preparátumkészítés során a fogak viszonylagos törékenysége és térgörbesége okozott.

\subsubsection{Szövettani preparátumok készítése}

A cement- és dentin-állomány vizsgálatát nem csak csiszolatokon, hanem hisztotechnikai előkészítés után is vizsgáltam. A szövettani vizsgálatokat az ELTE Állatszervezettani Tanszékén és a SZIE Anatómiai és Szövettani Tanszékén végeztük. Az alkalmazott hisztotechnikai folyamatot az alábbiakban lépésenként, mutatom be elsősorban KISZELY \& BARKA (1958), ROMEIS (1968), CHAYEN et al. (1973), KRUTSAY (1980, 1999), LESSON et al. (1985) VÍGH \& Kondics (1991), Dellman (1993), KüHNEL (1997), RöLICH (2002) és CsÁKi (2002) nyomán.

\subsubsection{Dekalcinálás}

Első lépésben dekalcinálni kellett a fogakat. Ezt a müveletet 5\%-os salétromsav oldatban végeztem. A dekalcinálás ideje a fog méretétől és kopottságától függően általában 1-4 nap volt. Nagyon lényegesnek bizonyult a dekalcinálás során, a fogak aktuális állapotának rendszeres napi 4-5-szöri - ellenőrzése. Tapasztalataim alapján a legjobb megoldás az, hogyha éjszakára kivesszük a fogakat a dekalcináló oldatból, és vízben tároljuk másnap reggelig, nehogy az a szükségesnél tovább legyen kitéve a sav hatásának. A fog akkor dekalcinálódik kellőképpen, amikor a koronáját kis átmérőjű tűvel át lehet szúrni úgy, hogy sercegő hang nem kíséri ezt a folyamatot.

A dekalcinálás elvégezhető hangyasav és formaldehid keverékével is (FANCY, 1980), de a tapasztalataim alapján ez az eljárás minimum 2, de akár 3 hétig, sőt még tovább is eltarthat. Az EDTA (etilén-diamin tetra-acetát) általánosan használt kelát-komplex képző vegyület is alkalmazható dekalcinálásra, de még lassabb, mint a hangyasav-formaldehid elegy. 


\subsubsection{Kimosás, neutralizálás}

A kimosási, neutralizálási folyamatot legegyszerübben 24 órán át tartó desztillált vizes fürdővel sikerült megoldani. Nem volt szükség a Low \& CowAN (1963) által javasolt lithiumkarbonátos neutralizálásra.

\subsubsection{Víztelenítés}

A víztelenítést egyre töményebb etanolban való fél-fél napos áztatással végeztük. Először 50\%-os, majd 80\%, 90\%, 96\%-os és végül kétszer abszolút etanolban történt a víztelenítés.

\subsubsection{4. Átderítés}

A mintákat toluolban egy napig átderítettük.

\subsubsection{5. Átitatás}

Az átitatást toluol paraplaszt keverékekben (2:1, 1:1, 1:2 arányban) végeztük 20-20 percig. Ezt követően 30 percig tiszta paraplasztot alkalmaztunk, s végül blokkokban 5-6 óráig folytattuk az átitatást, szintén tiszta paraplasztban. Az átitatási folyamat $60^{\circ} \mathrm{C}$-os termosztátban történt. Az átitatást követően jeges vízfürdőben végeztük a paraplaszt dermesztését.

\subsubsection{Metszés}

A metszést hagyományos szánka mikrotómmal végeztük. A metszetek vastagsága kb. $5 \mu \mathrm{m}$ volt.

\subsubsection{Festés}

A fentieknek megfelelő előkészítési folyamat után többféle festést is alkalmaztunk, melyeket az alábbiakban mutatok be.

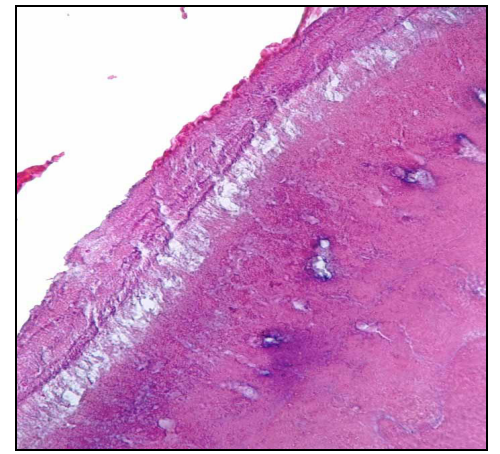

18. ábra: $M_{1}$-es fog gyökerének horizontális metszete, haematoxilin-eosin festés $(100 \times)$

Figure 18: Horisontal section from $\mathrm{M}_{1}$ teeth Hematoxilin-eosin staining $(100 \times)$

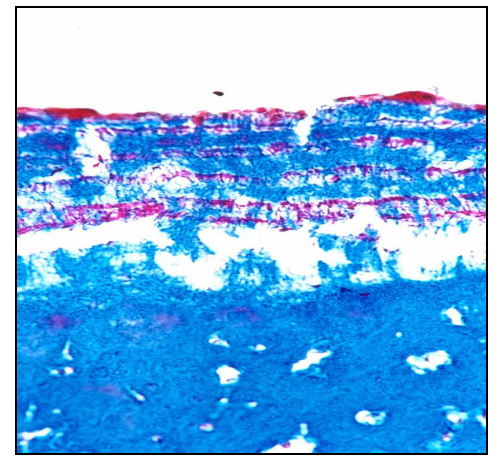

19. ábra: $M_{1}$-es fog gyökerének cementuma, azan festés $(240 \times)$

Figure 19: Horisontal section from cementum of $\mathrm{M}_{1}$ teeth staining Azan (240x) 


\section{Hematoxilin-eosin festés}

A deparafinálást xilolban, és abszolút etanolban végeztük. Azt követően 70\%-os alkoholban, majd desztillált vízben öblítettük a metszeteket. Az Erlich-féle hematoxilinban 15-60 másodpercet áztak a metszetek. Majd egy újabb öblítési folyamat után 0,1\%-os eosin oldatban végeztük a festést. Utána 96\%-os, majd abszolút alkoholban öblítettük, majd 10 másodpercig xilolba tettük és végül lefedtük a metszeteket (18. ábra).

\section{Heidenhain-féle Azan festés}

Az előzőekhez hasonló deparafinálási és öblítési folyamat után 5 percig azokármin oldatban végeztük a festést. Ezt követően mikroszkóp alatt végeztuik a differenciálást, alkoholos anilin oldatban, majd $1 \%$ ecetsavat tartalmazó etanol oldatban fixáltuk a festéket. A pácolást 5\%-os foszforwolfrámsavban végeztük 90 percig. Desztillált vizes öblítés után anilinkék-orange oldatban (módosított Mallory-oldatban) végeztük a festést. Ezt követte a víztelenítés, derítés és végül a lefedés (19. ábra).

\section{Goldner-féle trikróm-festés}

A deparafinálást követően vashematoxilinnal végeztünk festés, majd 5 percig csapvízben öblítettük a metszeteket. Majd 5 percig festettük savanyú fuxin $(0,1 \mathrm{~g})$, ponceau de xilidine $(0,2$ g), ecetsav $(0,6 \mathrm{ml})$ és desztillált víz (300 ml) keverékében. Ezt követően 0,2 \%-os ecetsavban öblítettünk, s majd a festést orange $\mathrm{G}(2,0 \mathrm{~g})$, foszforwolfrámsav $(4 \mathrm{~g})$ és desztillált víz (100 $\mathrm{ml})$ keverékében folytattuk. Újabb öblítés után a festést fényzöld $(0,2 \mathrm{~g})$, ecetsav $(0,2 \mathrm{ml})$ és desztillált víz $(100 \mathrm{ml})$ keverékében fejeztük be. Ezután újabb öblítés következett 0,2\%-os ecetsavban, majd etanolban. Ezt már csak víztelenítés, derítés és lefedés követte (20. ábra).

\section{Giemsa-festés}

A deparafinálást követően 4 óráig kell a metszeteket festeni Giemsa-törzsoldat (3 ml), nátrium-acetát $(0,05 \mathrm{~g})$, ecetsav $(0,1 \mathrm{ml})$ és desztillált víz $(100 \mathrm{ml})$ keverékében.

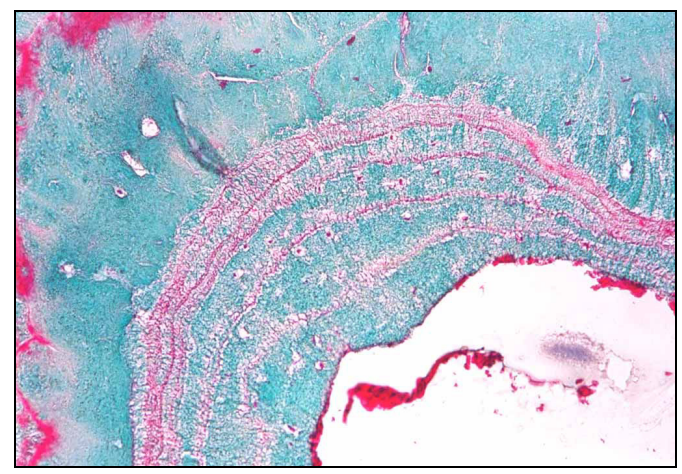

20. ábra: $M_{1}$-es fog gyökerének cementuma, Goldner-trikróm festés (240x)

Figure 20. Horisontal section from cementum of $\mathrm{M}_{1}$ teeth tricrom staining described by Goldner (240x)

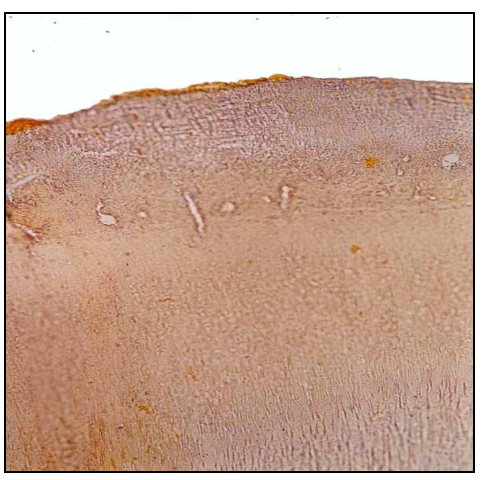

21. ábra: $M_{1}$-es fog gyökerének cementuma, ezüst impregnáció festés $(120 x)$ Figure 21. Horisontal section from cement of $\mathrm{M}_{1}$ teeth staining by silver impregnation (240x)

\section{Ezüstimpregnáció vagy argentaffin-reakció}

Az ezüstözés (ezüstimpregnáció vagy argentaffin-reakció) során az argentaffin szöveti struktúrák az ammóniás ezüstnitrát-oldatot ezüstté redukálják. A metszeteket ammóniás ezüstnitrát-oldatban, 24 óráig, sötét helységben helyezzük el. Ezután kétszer öblítjük desztillált vízben, majd 1 percig 5\%-os nátriumtioszulfát-oldatban fixáljuk. Újabb öblítést követően Krenechtrottal végezzük a festést. Ezt követi egy újabb öblítés, majd víztelenítés, derítés és 
lefedés. Az eljárást követően az argentaffin szövetrészek barnák vagy feketék lesznek (21. ábra).

\subsubsection{Elekronmikroszkópos preparátumok készítése}

A fogak cementállományát vizsgáltuk pásztázó elektronmikroszkóppal is (22-23. ábra). Ennek során - részben - felhasználtuk a már elkészített fogcsiszolat-preparátumokat, amelyeket úgy készítettünk elő, hogy a preparátumok vizsgálandó felületét vákuumgőzölőben $20 \mathrm{~nm}$ vastag szénréteggel vontuk be (GÁLNÉ, 1997). A preparátumok oldalait széngyurmával borítottuk be, a vizsgálathoz szükséges vezető képesség kialakítása érdekében. A vizsgálatainkat megismételtük úgy is, hogy a gyökérívben lévő vastagabb cementállományt lerepesztettük a dentinről, s egy széthajtogatott gémkapocsra téve, a cementre két oldalról nyomást gyakorolva sagittális irányban eltörtük. A tört preparátumokat is az előzőekhez hasonlóan szénnel vontuk be. Az elekronmikroszkópos vizsgálatokat az ELTE Kőzettani és Geokémiai Tanszékének RTG Mikroszonda Laborjában végeztuik.

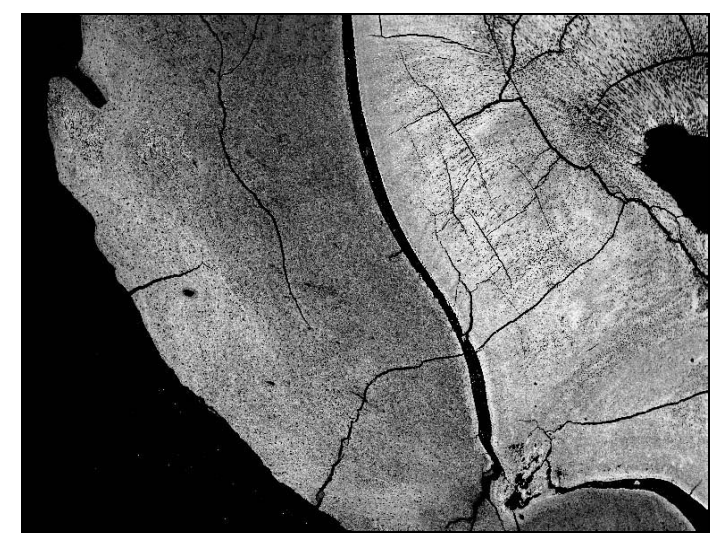

22. ábra: $M_{1}$-es fog gyökérívének cementuma, transzmissziós EM

Figure 22: Transversal section from cement of $\mathrm{M}_{1}$ teeth, Transmission EM

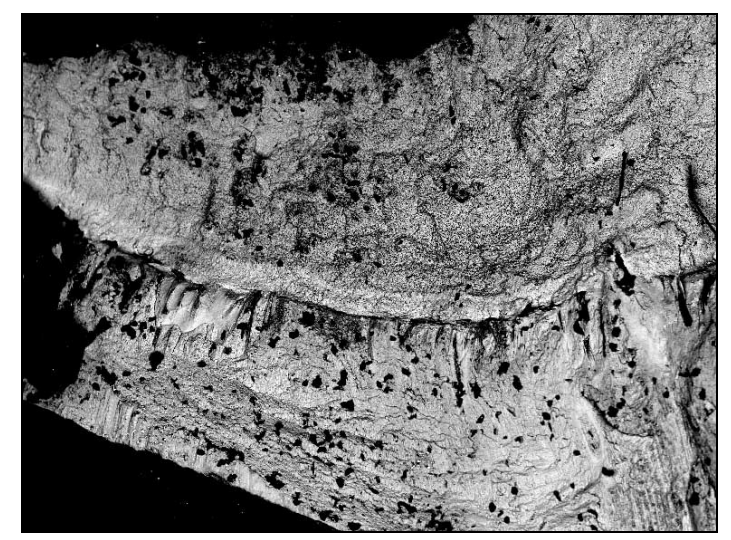

23. ábra: $M_{1}$-es fog gyökérívének cementuma, scanning EM

Figure 23: Transversal section from cement of $M_{1}$ teeth, Scanning EM

\subsubsection{A trófeabírálati korbecslés}

Vizsgálataimnál a vadászati hatóság által megállapított hivatalos trófeabírálati kort összehasonlítottam a fogak cementzónái alapján becsült korral, és ez alapján értékeltem a trófeabírálati korbecslés pontosságát és megbízhatóságát.

\subsubsection{A terepi korbecslés}

A terepen becsült kort a területen dolgozó hivatásos vadászok állapították meg az elejtés előtt. A becslést az élő őz testfelépítése, testtáj arányai, agancsa és a viselkedése alapján, a 2.2. „Az élő őz terepi korbecslése" címü alfejezetben leírtak szerint végezték.

\subsubsection{Az orrsövény elcsontosodása}

Az orrsövény elcsontosodásának mértékéböl RAJNIK (1977) módszere szerint becsültük a kort (2.4.8. „A RAJNIK-módszer” című alfejezetben leírtak szerint). 


\section{AZ EREDMÉNYEK ISMERTETÉSE ÉS ÉRTÉKELÉSE}

Az alábbiakban bemutatom a korbecslési módszerek és azt követően a korra utaló bélyegek vizsgálatainak eredményét és értékelésüket.

\subsection{A cementállomány vizsgálatának értékelése}

\subsubsection{A fogcsiszolatokon megfigyelhető cementzónák vizsgálatának értékelése}

A cementállomány értékelésének tapasztalatait az alábbiakban mutatom be:

- $\quad$ Az állkapocs $\mathrm{M}_{1}$-es fogait vizsgálva az esetek 60\%-ban a gyökérívben képződött cementzónák alapján becsülhető volt a kor. Ha az $\mathrm{M}_{1}$ gyökérívének alapján nem volt a kor megbecsülhető a zónák képződésének értékelhetetlensége miatt, olyankor jellemzően az $\mathrm{M}_{2}$ és az $\mathrm{M}_{3}$ gyökérívének cementállománya sem mutatott olyan rétegződést, amely alapján a kor becsülhetö lett volna (24. ábra).

- Azokban az esetekben, amikor a cementállományban a zónák nem különültek el jól kivehető formában a mikroszkóp fényforrásának az erősségét, irányát, és a fényforrás kicserélésével a színhőmérsékletét megváltoztattam és ezt követően újra vizsgáltam a preparátumot. Ha ez sem hozott kellő eredményt a ráeső fényt, a vizsgálati tárgy felett 5-6 mm magasságban kitakartam egy vékony 2 vagy $3 \mathrm{~mm}$ szélességü fotókarton csík segítségével. Így sikerült azt elérni, hogy nem a tárgy felületéről visszaverődő fény által létrehozott képet lehetett vizsgálni, hanem a fogon keresztül haladó fény alkotta kép vált megfigyelhetővé. Mindezek segítségével az értékelést legtöbbször újabb preparátum készítése nélkül is el tudtam végezni.

- $\quad$ Az előzápfogak gyökérívében akkor is ritka volt a rétegződés, ha az $\mathrm{M}_{1}$-nél jól látható volt. Azokban az esetekben, amikor az utózápfogak gyökérívének alapján nem tudtam kort becsülni, a foggyökér alsó $14_{4}{ }^{1}{ }_{3}$-ánál készített horizontális csiszolatot nagyon alaposan megvizsgálva a metsző, az előzáp- és az utózápfogaknál megfigyelt rétegződött cementállomány alapján becsültem meg a kort. Az esetek 6,5\%-ában előfordult, hogy csak többszöri fogcsiszolat készítés után jutottam olyan preparátumhoz, amely alapján a korbecslés a lehetőségekhez képest egzaktul elvégezhető volt.

- $\quad$ Így minden esetben tudtam kort becsülni, szemben BRIEL (1978) 11\%-os eredményével.

- A maxilláris fogaknál a cementállományban rétegződés alig, vagy egyáltalán nem volt látható, úgy a gyökérív transzverzális, mint a foggyökér horizontális csiszolataiban. 68 őz maxilláris fogainak cementállomány vizsgálata során egyetlen esetben sem tudtam az életkorra következtetni.

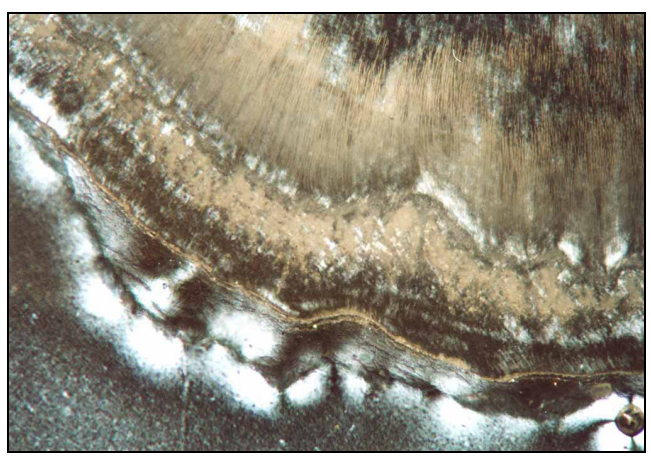

24. ábra: $M_{1}$-es fog gyökerének horizontális csiszolata polarizált fényben (100x)

Figure 24: Transmitted horizontal $\mathrm{M}_{1}$ teeth polished section in polarized light 
- Vékony átvilágítható csiszolatok esetén nem találtam jól értékelhető zónákat, sem a mandibuláris, sem a maxilláris fogaknál, még polarizált fényben történő értékeléskor sem.

- $\quad$ Mindezek alapján igen jól használható módszernek minősíthető a magyarországi élőhelyi viszonyok között az alsófogsor fogainak cementzónái alapján végzett korbecslés. Valószínüsíthető, hogy az állkapocs fogainak cementréteg vizsgálata nagyobb minta elemszám esetén sem hoz érdemi eredményváltozást hazai körülmények között.

\subsubsection{A cementzónák hisztotechnikai vizsgálatának értékelése}

A hisztotechnikai vizsgálatok során a különböző festési eljárásokat értékelve megállapítható, hogy a Goldner-féle trikróm, a Heidenhain-féle azan, és a Giemsa-féle festési eljárások bizonyultak a leginformatívabbnak. A haematoxilin-eosin festés is értékelhetö eredményt ad, de az elöbbi három eljárás sokkal könnyebben értékelhetö, és jobban differenciált eredményt ad. Az ezüst impegnációs eljárás nem nyújtott értékelhető eredményt. Mindezek alapján javasolható, a Giemsa-féle festés alkalmazása a korbecslési célú szövettani vizsgálatokban a cementállomány értékelésére. E módszer egyetlen hátránya, hogy rendkívül gyorsan fakulnak a metszetek. Ami azt jelenti, hogy azok elkészülte után néhány órával, vagy lehetőleg kevesebb, mint egy nappal az értékelésüket elkészítsük, mert a Giemsa-szerint festett metszetek az elkészültük után azonnal elkezdenek fakulni, és néhány nap után a metszetek pontosan már nem értékelhetőek. Egy-két hét elteltével gyakorlatilag teljesen elvesztik színüket.

Az elektronmikroszkópos vizsgálatokat értékelve megállapíthatjuk, hogy sem a tört felületekről készített szkenning, sem a polírozott felületekről készített visszavert elektronkép, sem a transzmissziós eljárás nem hozott értékelhető eredményeket. A cementum zónái egyik módszer esetében sem tüntek elő.

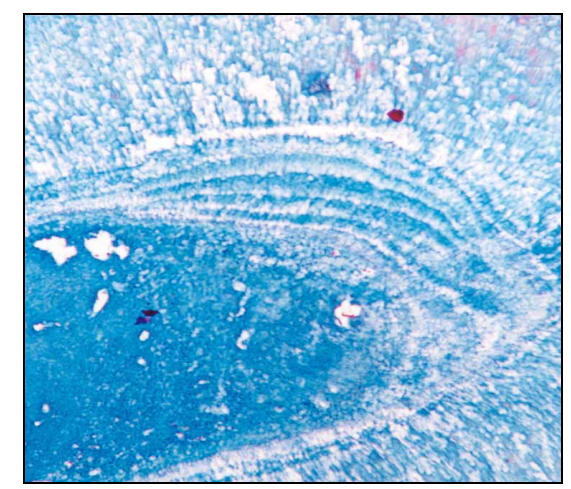

25. ábra $M_{1}$-es fog gyökerének secundaer dentinje, azan festés (240x)

Figure 25: Horisontal section from secundaer dentin of $M_{1}$ teeth staining Azan (240x)

\subsection{A pótdentin-vizsgálatok értékelése}

Az $\mathrm{I}_{1}$-es fogak sagittális csiszolatával nyert 105 preparátumból mindössze hatnál találtam enyhén látható sávokat, amelyek száma az életkorral kapcsolatot nem mutatott. Így ezt a módszert nem tartom alkalmasnak az őz korbecslésére.

Ezzel szemben a hisztotechnikai eljárással készült, festett szövettani metszetek ugyanolyan jól értékelhetők, mint a cementum metszetei. A pótdentin szakaszos növekedésének eredményeként a pulpa üregét szűkítő zónák jól elkülöníthetőek egymástól. Érékelhetőségük idős egyedeknél is kiváló. A tapasztalataim azt mutatják, hogy a cementum vizsgálatánál is jól használható Goldner-féle trikróm, a Heidenhain-féle azan, és a Giemsa-féle festési eljárások a leginformatívabbak. A haematoxilin-eosin festés is értékelhető eredményt ad, akárcsak a 
cementum esetében, de az elöbbi három hisztotechnikai eljárás sokkal könnyebben értékelhető, és jobban differenciált eredményt ad.

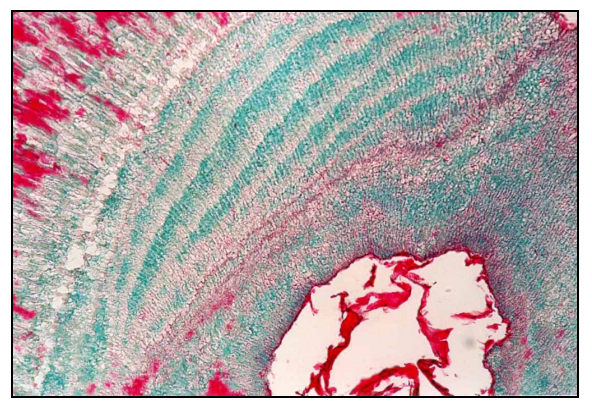

26. ábra $M_{1}$-es fog gyökerének secundaer dentinje, Goldner-trikróm festés (240x)

Figure 26: Horizontal section from seconder dentin of $M_{1}$ teeth tricrom staining described by Goldner (240x)

\subsection{A cementzónák alapján becsült kor és a fogkopás alapján becsült kor összehasonlí-} tása

A cementzónák és a fogkopás alapján becsült kort Tolna, Győr-Moson-Sopron és Békés megyei bakoknál, illetve Tolna megyei sutáknál vizsgáltam meg összesen 635 adatpár segítségével. A tolnai bakoknál 356 adatpár segítségével végeztem a vizsgálatokat. A becsült kor 87,64 \%-ban egyezett meg, 11,24 \%-ban egy év, 1,12 \%-ban két év eltérés volt közöttük. Az adatpárokat regresszió és korreláció analízissel is vizsgáltam. A korrelációs koefficiens számított értéke ( $\mathrm{r}=0,9791)$ igen magas, jóval meghaladja a kutatásban elfogadott $95 \%$-os megbízhatósági szint $(\mathrm{P}=0,05 ; \mathrm{DF}=355)$ kritikus korrelációs koefficiens értékét $\left(\mathrm{r}^{*}=0,1779\right)$. Így megállapítható, hogy az adatok között szoros, statisztikailag igazolható kapcsolat van. A determinációs koefficiens $\left(r^{2}=0,9587\right)$ értékének százszorosa megmutatja, hogy a cementzónák alapján becsült kor 95,87 \%-ban befolyásolja a fogkopás mértékét a vizsgált mintában. A két módszer regresszióját az alábbiakban ábrázoltam (27. ábra).

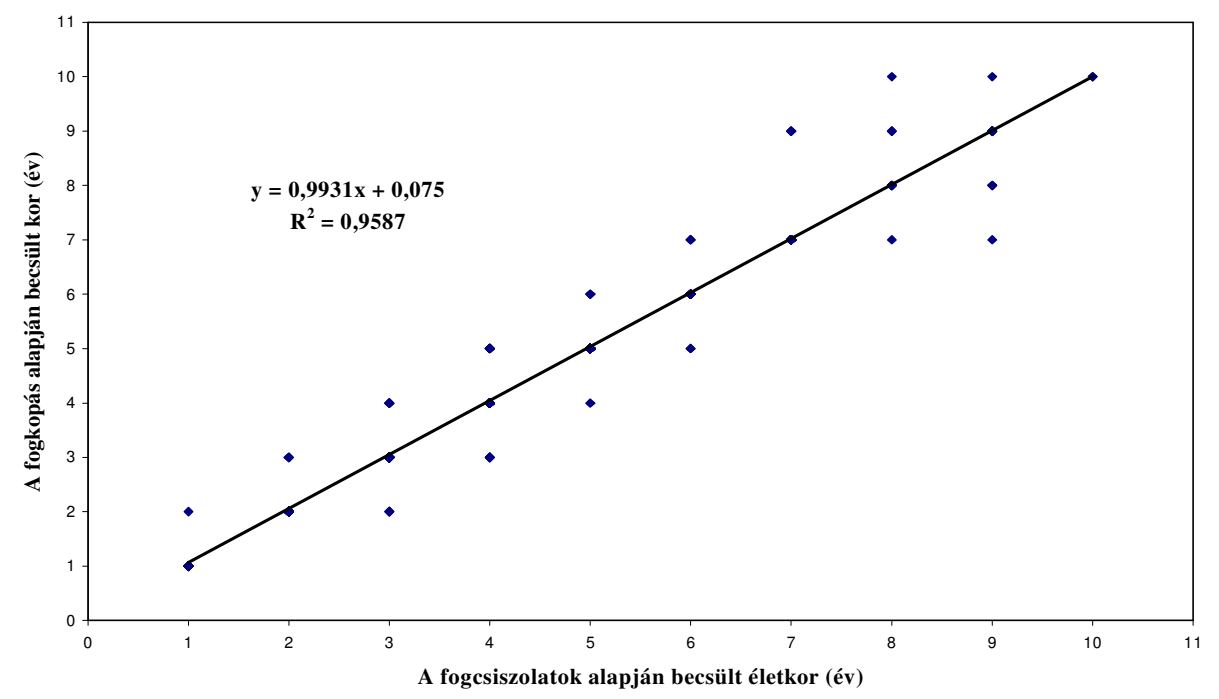

27. ábra: A cementzónák és a fogkopás alapján becsült kor regressziója tolnai őzbakoknál $(\mathbf{n = 3 5 6})$

Figure 27: Regression between age estimation based on cement layers and age estimation based on tooth wear at roe deer bucks from Tolna County $(n=356)$ 
A szórásnégyzeteket (varianciákat) F-próbával hasonlítottam össze. A számított F-érték $(\mathrm{F}=0,9720)$ meghaladja a táblázati kritikus éréket $\left(\mathrm{F}^{*}=0,8396\right)$, így a varianciák között különbség mutatható ki. Az adatokat összehasonlítottam egymintás z-próbával is. A számított z érték ( $\mathrm{z}=-0,3110)$ abszolút értéke jóval alatta marad $95 \%$-os megbízhatóság mellett ( $\mathrm{P}=0,05$; $\mathrm{DF}=355)$ a kritikus z-értéknek $\left(\mathrm{z}^{*}=1,9600\right)$, tehát a középértékek között, nincs statisztikailag kimutatható különbség. A két módszerrel becsült kor átlagának különbsége 0,045 év. Azaz a fogkopás alapján becsült kor átlagban alig mutatott többet, mint a cementzónák alapján becsült kor.

A lajtai bakoknál 86 adatpár segítségével végeztem a vizsgálatokat. A becsült kor 81,39 \%-ban egyezett meg, 16,28 \%-ban egy év, 2,33 \%-ban két év eltérés volt közöttük. A korrelációs koefficiens számított értéke $(\mathrm{r}=0,9691)$ szintén igen magas, jóval meghaladja a mezőgazdasági kutatásban elfogadott 95 \%-os megbízhatósági szint $(\mathrm{P}=0,05 ; \mathrm{DF}=85)$ kritikus korrelációs koefficiens értékét ( $\left.\mathrm{r}^{*}=0,2172\right)$. Így megállapítható, hogy az adatok között szoros, statisztikailag igazolható kapcsolat van. A determinációs koefficiens $\left(\mathrm{r}^{2}=0,9391\right)$ értékének százszorosa megmutatja, hogy a cementzónák alapján becsült kor 93,91\%-ban befolyásolja a fogkopás mértékét a vizsgált mintában. A szórásnégyzeteket (varianciákat) F-próbával hasonlítottam össze. A számított F-érték $(\mathrm{F}=0,9651)$ meghaladja a táblázati kritikus éréket $\left(F^{*}=0,6884\right)$, így a varianciák között különbség mutatható ki. A számított z érték $(\mathrm{z}=-0,0748)$ abszolút értéke jóval alatta marad $95 \%$-os megbízhatóság mellett $(\mathrm{P}=0,05 ; \mathrm{DF}=85)$ a kritikus z-értéknek $\left(\mathrm{z}^{*}=1,9600\right)$, tehát a középértékek között nincs statisztikailag kimutatható különbség. A két módszerrel becsült kor átlagának különbsége 0,045 év. Azaz a fogkopás alapján becsült kor gyakorlatilag nem mutatott többet, mint a cementzónák alapján becsült kor.

A Békés-megyei bakoknál 56 adatpár segítségével végeztem a vizsgálatokat. A becsült kor 75,00 \%-ban egyezett meg, 23,10 \%-ban egy év, 1,79\%-ban két év eltérés volt közöttük. A korrelációs koefficiens számított értéke $(\mathrm{r}=0,9732)$ szintén igen magas, jóval meghaladja a mezőgazdasági kutatásban elfogadott $95 \%$-os megbízhatósági szint $(\mathrm{P}=0,05 ; \mathrm{DF}=55)$ kritikus korrelációs koefficiens értékét $\left(\mathrm{r}^{*}=0,2732\right)$. Így megállapítható, hogy az adatok között szoros, statisztikailag igazolható kapcsolat van. A determinációs koefficiens $\left(\mathrm{r}^{2}=0,9471\right)$ értékének százszorosa megmutatja, hogy a cementzónák alapján becsült kor 94,71 \%-ban befolyásolja a fogkopás mértékét a vizsgált mintában. A varianciákat F-próbával hasonlítottam össze. A számított F-érték $(\mathrm{F}=0,9651)$ meghaladja a táblázati kritikus éréket $\left(\mathrm{F}^{*}=0,6884\right)$, így a varianciák között különbség mutatható ki. A számított z érték $(\mathrm{z}=-0,1215)$ abszolút értéke jóval alatta marad $95 \%$-os megbízhatóság mellett $(\mathrm{P}=0,05 ; \mathrm{DF}=55)$ a kritikus z-értéknek $\left(\mathrm{z}^{*}=1,9600\right)$, tehát a középértékek között nincs statisztikailag kimutatható különbség. A két módszerrel becsült kor átlagának különbsége 0,054 év. Azaz a fogkopás alapján becsült kor gyakorlatilag nem mutatott többet, mint a cementzónák alapján becsült kor.

A Tolna-megyei őzsutáknál 138 adatpár segítségével végeztem a vizsgálatokat. A becsült kor 78,10 \%-ban egyezett meg, 18,98 \%-ban egy év, 2,92 \%-ban két év eltérés volt közöttük. A korrelációs koefficiens számított értéke ( $\mathrm{r}=0,9744)$ szintén igen magas, jóval meghaladja a mezőgazdasági kutatásban elfogadott $95 \%$-os megbízhatósági szint $(\mathrm{P}=0,05$; $\mathrm{DF}=136)$ kritikus korrelációs koefficiens értékét $\left(\mathrm{r}^{*}=0,1779\right)$. Így megállapítható, hogy az adatok között szoros, statisztikailag igazolható kapcsolat van. A determinációs koefficiens $\left(r^{2}=0,9494\right)$ értékének százszorosa megmutatja, hogy a cementzónák alapján becsült kor 94,94 \%-ban befolyásolja a fogkopás mértékét a vizsgált mintában. A számított F-érték $(\mathrm{F}=1,0960)$ nem éri el a kritikus éréket $\left(\mathrm{F}^{*}=1,326\right)$, így a varianciák között különbség nem mutatható ki. A számított z érték ( $\mathrm{z}=0,3337)$ abszolút értéke jóval alatta marad $95 \%$-os megbízhatóság mellett $(\mathrm{P}=0,05 ; \mathrm{DF}=355)$ a kritikus z-értéknek $\left(\mathrm{z}^{*}=1,9600\right)$, tehát a középértékek között nincs statisztikailag kimutatható különbség. A két módszerrel becsült kor átlagának különbsége 0,1 
év. Azaz a cementzónák alapján becsült kor statisztikailag nem mutatott többet, mint a fogkopás alapján becsült kor.

A fentiek alapján elmondható, hogy a cementzónák alapján és a fogkopás módszerével becsült kor $95 \%$-os megbízhatóság mellett azonosnak nem tekinthetőek, de egymáshoz kiemelkedően jól közelítenek. Ezek szerint a precízen végzett fogkopás alapján történő korbecslés a legjobb gyakorlati módszer.

\subsection{A cementzónák száma alapján becsült kor és a trófeabírálati kor összehasonlítása}

A cementzónák és a trófeabírálaton becsült kort Tolna- és Békés-megyei bakoknál vizsgáltam meg összesen 399 adatpár segítségével.

A tolnai bakok esetében 343 adatpár felhasználásával értékeltem a cementzónák száma alapján becsült és a trófeabírálati kort. Az adatok 35,96 \%-ban megegyeztek, 39,61 \%-ban egy év eltérés, 15,45\%-ban két év eltérés, 6,73\%-ban három év eltérés, 1,69\%-ban négy év eltérés, 0,28\%-ban (egy esetben) hat év eltérést és 0,28\%-ban (egy esetben) nyolc év eltérést mutattak. A korrelációs koefficiens számított értéke $(\mathrm{r}=0,6380)$ eléri a mezőgazdasági kutatásban elfogadott $95 \%$-os megbízhatósági szint mellett $(\mathrm{P}=0,05 ; \mathrm{DF}=342)$ a kritikus korrelációs koefficiens értékét $\left(\mathrm{r}^{*}=0,1779\right)$. Ezek alapján a vizsgált minta statisztikailag igazolható kapcsolatot mutat. A determinációs koefficiens értéke $\left(\mathrm{r}^{2}=0,4070\right)$ szerint a cementrétegek alapján becsült kor 40,70 \%-ban határozza meg a trófeabírálati kort. A két módszer regresszióját az alábbiakban ábrázoltam (28. ábra).

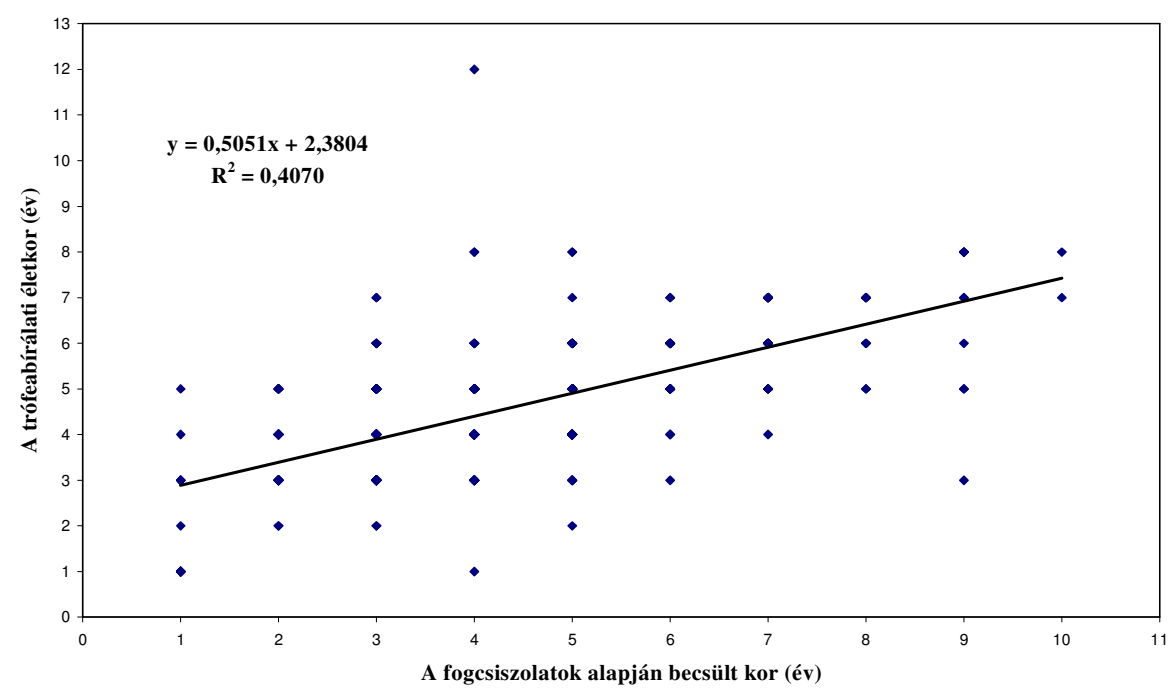

\section{8. ábra: A cementzónák alapján becsült kor és a trófeabírálati kor regressziója tolnai bakoknál $(n=343)$}

Figure 28: Regression between age estimation based on cement layers and age estimation based on trophy at roe deer bucks from Tolna County

A szórásnégyzeteket (varianciákat) F-próbával hasonlítottam össze. A számított Férték $(\mathrm{F}=1,5987)$ nem haladja meg a táblázati kritikus éréket $\left(\mathrm{F}^{*}=1,932\right)$, így a varianciák között különbség nem mutatható ki. Az adatokat összehasonlítottam egymintás z-próbával is. A számított z érték $(\mathrm{z}=-1,5398)$ abszolút értéke alatta marad 95\%-os megbízhatóság mellett $(\mathrm{P}=0,05 ; \mathrm{DF}=342)$ a kritikus z-értéknek $\left(\mathrm{z}^{*}=1,9600\right)$, tehát a középértékek között nincs statisztikailag kimutatható különbség. A két módszerrel végzett korbecslési eljárás átlaga 0,2 év 
eltérést mutatott a trófeabírálati kor javára. Ez az érték a z-próba eredménye szerint statisztikailag jelentéktelennek tekintendő.

A békési bakok esetében 56 adatpár felhasználásával végezem vizsgálataimat. Az adatok 39,28 \%-ban megegyeztek, 14,28\%-ban egy év eltérés, 8,93\%-ban két év eltérés, 19,64 \%-ban három év eltérés, 14,28 \%-ban négy év eltérés, 1,79\%-ban (egy esetben) öt év eltérést és 1,79\%-ban (egy esetben) hat év eltérést mutattak. A két módszerrel végzett korbecslési eljárás átlaga 0,71 év eltérést mutatott a trófeabírálati kor javára. A korrelációs koefficiens számított értéke ( $\mathrm{r}=0,4882)$ eléri a mezőgazdasági kutatásban elfogadott 95\%-os megbízhatósági szint mellett $(\mathrm{P}=0,05 ; \mathrm{DF}=55)$ a kritikus korrelációs koefficiens értékét $\left(\mathrm{r}^{*}=0,2383\right)$. Ezek alapján a vizsgált minta gyenge statisztikailag igazolható kapcsolatot mutat. A számított F-érték $(F=0,9920)$ meghaladja a táblázati kritikus éréket $\left(F^{*}=0,6393\right)$, így a varianciák között különbség mutatható ki. A számított z érték $(\mathrm{z}=-1,6613)$ abszolút értéke alatta marad $95 \%$-os megbízhatóság mellett $(\mathrm{P}=0,05 ; \mathrm{DF}=55)$ a kritikus z-értéknek $\left(\mathrm{z}^{*}=1,9600\right)$, tehát a középértékek között, nincs statisztikailag kimutatható különbség.

Az adatsorok között nem túl markáns különbség mutatkozott meg, s ennek oka a vadászati felügyelök felkészültségének és tapasztalatának különbségeiből adódott.

Mivel alig több, mint az esetek egyharmadában egyezett meg a két módszerrel becsült életkor, a kapcsolatot a nem túl magas korrelációs és determinációs koefficiensek miatt a gyakorlat szempontjából gyengének minősíthetjük. A trófeabírálati korbecslés pontatlanságának okai:

1. A trófeabírálaton a kort legtöbbször az agancs jellege, a koszorúk és az agancstő dőlése, a koponyacsont vastagsága és a koponyavarratok elcsontosodása alapján becsülik. Ezek a módszerek gyenge, legfeljebb közepes erősségű kapcsolatba hozhatók a korral. Pontatlan bélyegekből nem lehet pontos kort becsülni.

2. A trófeabírálati szankciók, azaz mínusz pontok elkerülésének lehetősége (erre a túlbecsült korok utalnak).

3. Sokszor felületes a trófeabírálatkor a kor megállapítása (erre az alul- és a túlbecslés is utal).

4. A kiskoponyás trófeabírálatkor sokszor nem követelik meg a levágott koponyarész bemutatását, vagy azt nem veszik figyelembe. Így a fogkopás mértékének alapulvétele nem tudja pontosítani a becsült trófeabírálati kort.

\subsection{A cementzónák száma alapján becsült kor és a terepen becsült kor eredményeinek összehasonlítása}

A cementzónák száma alapján becsült kor és a terepi korbecslés eredményeinek összehasonlítását Tolna- és Békés-megyei bakoknál összesen 333 adatpár segítségével végeztem el.

A tolnai bakok esetében 277 adatpár segítségével végeztem vizsgálataimat. Az adatok 37,91\%-ban megegyeztek, 32,13\%-ban egy év eltérés, 20,94\%-ban két év eltérés, 11,19\%-ban három év eltérés, 2,17\%-ban négy év eltérés és 1,08\%-ban (három esetben) hat év eltérést mutattak. A korrelációs koefficiens számított értéke ( $\mathrm{r}=0,5911)$ eléri a mezőgazdasági kutatásban elfogadott $95 \%$-os megbízhatósági szint mellett $(\mathrm{P}=0,05 ; \mathrm{DF}=276)$ a kritikus korrelációs koefficiens értékét $\left(\mathrm{r}^{*}=0,1779\right)$. Ezek alapján a fogcsiszolatokkal végzett korbecslési eljárás és a terepen becsült kor között statisztikailag igazolható kapcsolatot van. A determinációs koefficiens értéke $\left(r^{2}=0,3494\right)$ szerint a cementrétegek alapján becsült kor 34,94 \%-ban határozza meg a terepen becsült kort. A két módszer regresszióját a Tolna-megyei őzbakoknál az alábbiakban ábrázoltam (29. ábra). 


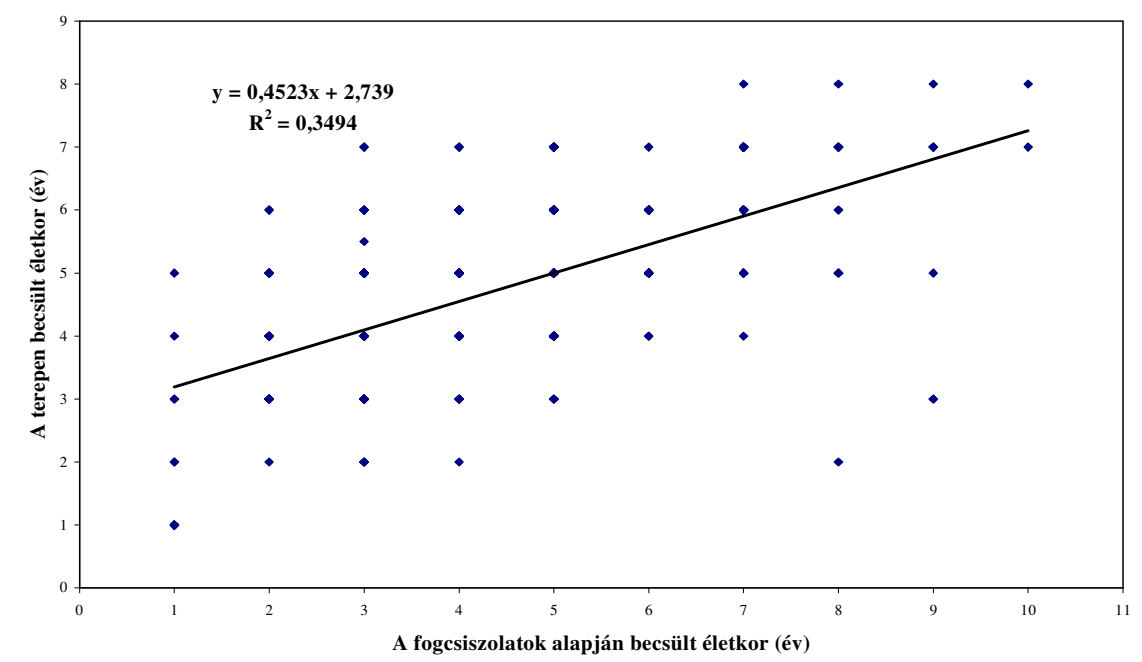

\section{9. ábra: A cementzónák alapján becsült kor és a terepen becsült kor regressziója tolnai bakoknál $(\mathbf{n}=277)$}

Figure 29: Regression between age estimation based on cement layers and age estimation based on living animal in field at roe deer bucks from Tolna County

A számított F-érték $(\mathrm{F}=1,7083)$ meghaladja a táblázati kritikus éréket $\left(\mathrm{F}^{*}=1,2194\right)$, így a varianciák között különbség mutatható ki. Az adatokat összehasonlítottam egymintás zpróbával is. A számított z érték $(\mathrm{z}=-2,4486)$ abszolút értéke meghaladja $95 \%$-os megbízhatóság mellett $(\mathrm{P}=0,05 ; \mathrm{DF}=276)$ a kritikus $\mathrm{z}$-értéket $\left(\mathrm{z}^{*}=1,9600\right)$, tehát a középértékek között statisztikailag kimutatható különbség van. A két módszerrel becsült kor átlagának különbsége 0,348 év.

A békési bakok esetében 56 adatpár felhasználásával értékeltem a fogcsiszolatok és a terepi korbecslés kapcsolatát. Az adatok 53,57\%-ban megegyeztek, 37,5 \%-ban egy év eltérés és 8,93\%-ban két év eltérés volt kimutatható. A korrelációs koefficiens számított értéke $(\mathrm{r}=0,9062)$ eléri a mezőgazdasági kutatásban elfogadott $95 \%$-os megbízhatósági szint mellett $(\mathrm{P}=0,05 ; \mathrm{DF}=55)$ a kritikus korrelációs koefficiens értékét $\left(\mathrm{r}^{*}=0,2383\right)$. Ezek alapján a vizsgált minta statisztikailag igazolható szoros kapcsolatot mutat. A determinációs koefficiens értéke $\left(r^{2}=0,8212\right.$ szerint a cementrétegek alapján becsült kor 82,12\%-ban határozza meg a terepen becsült kort. A számított F-érték $(\mathrm{F}=1,0425)$ nem éri el a táblázati kritikus éréket $\left(\mathrm{F}^{*}=1,5643\right)$, így a varianciák között különbség nem mutatható ki. A számított $\mathrm{z}$ érték ( $\mathrm{z}=-$ 1,4205) abszolút értéke alatta marad 95 \%-os megbízhatóság mellett $(\mathrm{P}=0,05 ; \mathrm{DF}=55)$ a kritikus z-értéknek $\left(\mathrm{z}^{*}=1,9600\right)$. Tehát a középértékek közötti 0,179 év eltérés statisztikailag elhanyagolhatónak tekintendő. A két módszer regresszióját a Békés-megyei bakok esetében az alábbiakban ábrázoltam (30. ábra).

A két mintaterületen tapasztalt eltérés okaként a terepen dolgozó hivatásos vadászok felkészültségében rejlö különbségeket lehet felhozni, ugyanis a tolnai mintaterületen dolgozó hivatásos vadászok középfokú szakképesítéssel rendelkeztek, míg a békési területen egy a munkájára nagyon igényes és jól felkészült vadgazda mérnök végezte a terepi korbecsléseket.

\subsection{A terepen becsült kor és a trófeabírálati kor összehasonlítása}

A terepen becsült kor és a trófeabírálati kor összehasonlítását 305 őzbak adatpárjának segítségével végeztem el. 


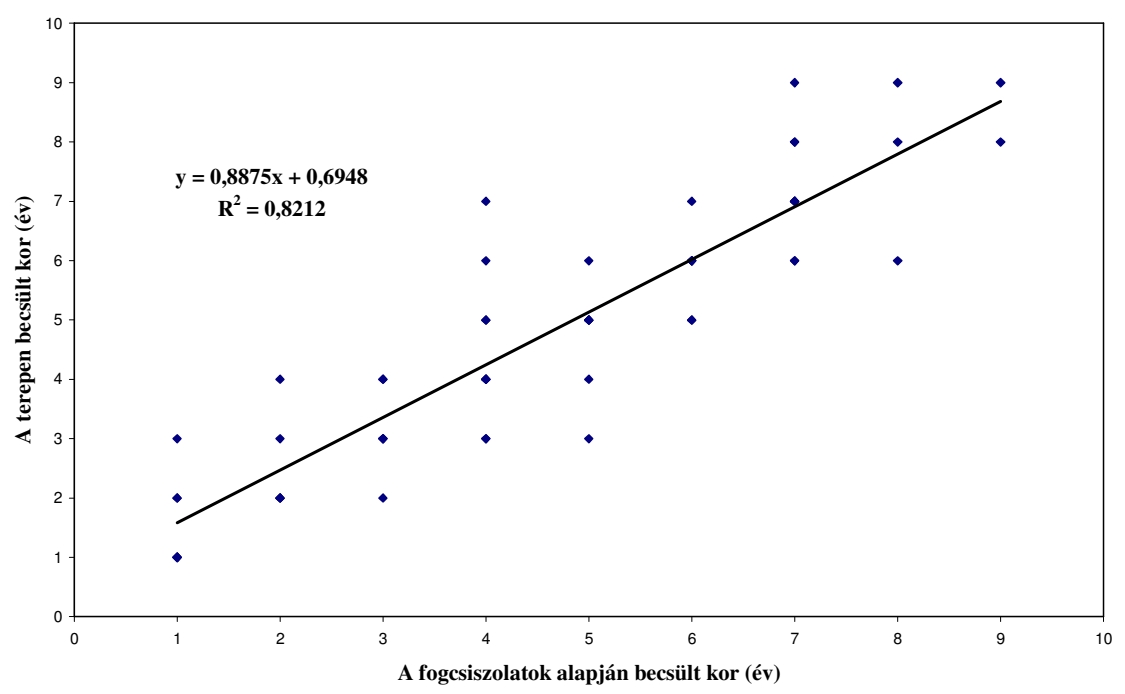

\section{0. ábra: A cementzónák alapján becsült kor és a terepen becsült kor regressziója békési} bakoknál $(\mathbf{n = 5 6})$

Figure 30: Regression between age estimation based on cement layers and age estimation based on trophy at roe deer bucks from Békés County $(\mathrm{n}=56)$

A tolnai mintából összesen 249 egyed esetében rendelkeztem mind a két adattal. Az adatok 45,38 \%-ban megegyeztek, 36,95\%-ban egy év eltérés, 10,44\%-ban két év eltérés, 4,02\%-ban három év eltérés, 1,21\%-ban négy év eltérés, 1,61\%-ban (négy esetben) öt év eltérést és $0,40 \%$-ban (egy esetben) hét év eltérést mutattak. A korrelációs koefficiens számított értéke $(\mathrm{r}=0,5552)$ meghaladja $(\mathrm{P}=0,05 ; \mathrm{DF}=248)$ a kritikus korrelációs koefficiens értékét $\left(\mathrm{r}^{*}=0,1779\right)$. Ezek alapján a terepen becsült kor és a trófeabírálati kor között statisztikailag igazolható kapcsolatot van. A determinációs koefficiens értéke $\left(r^{2}=0,3082\right)$ szerint a terepen becsült kor 30,82 \%-ban határozza meg a trófeabírálati kort. A két módszer regresszióját az alábbiakban mutatom be (31. ábra).

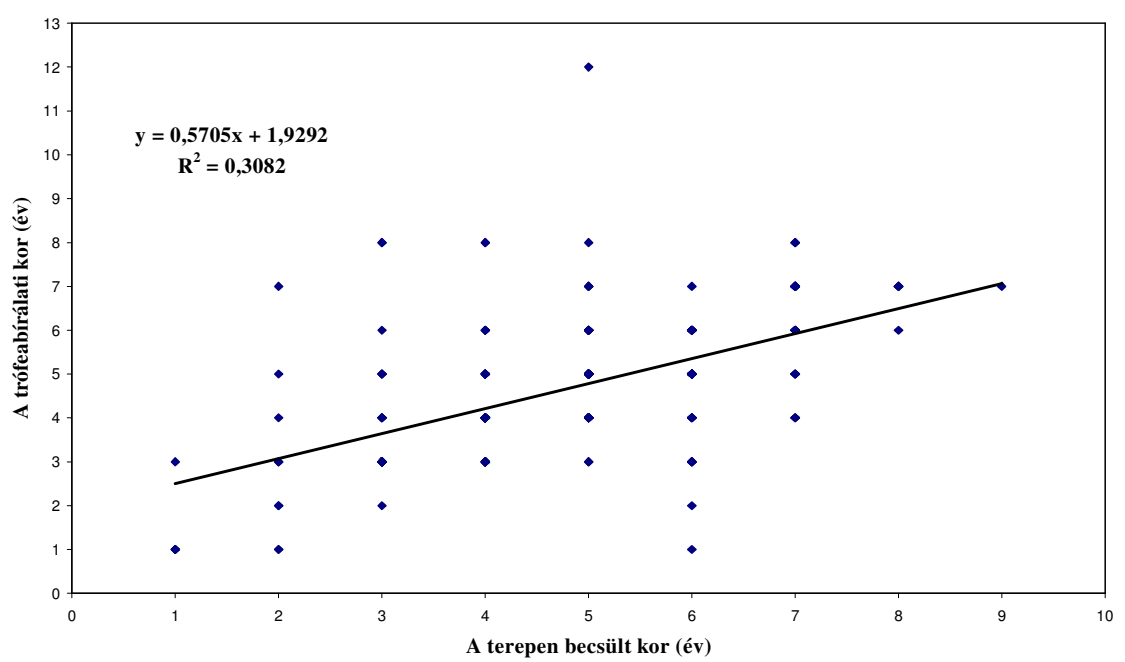

31. ábra: A terepen becsült kor és a trófeabírálati kor regressziója tolnai bakoknál $(n=249)$

Figure 31: Regression between age estimation based on living animal in field and age estimation based on trophy at roe deer bucks from Tolna County 
A békési bakok esetében 56 adatpár segítségével végeztem az elemzéseket. Az adatok 30,35 $\%$-ban megegyeztek, 30,35 \%-ban egy év eltérés, 17,86 \%-ban két év eltérés, 12,50\%-ban három év eltérés, 7,14 \%-ban négy év eltérés és 1,79\%-ban (egy esetben) hat év eltérés volt kimutatható. A korrelációs koefficiens számított értéke ( $\mathrm{r}=0,4875)$ eléri a mezőgazdasági kutatásban elfogadott $95 \%$-os megbízhatósági szint mellett $(\mathrm{P}=0,05 ; \mathrm{DF}=55)$ a kritikus korrelációs koefficiens értékét ( $\left.\mathrm{r}^{*}=0,2383\right)$. Ezek alapján a vizsgált változó között statisztikailag igazolható kapcsolatot van. A determinációs koefficiens értéke $\left(\mathrm{r}^{2}=0,2377\right)$ szerint a terepen becsült kor 23,77 \%-ban határozza meg a trófeabírálati kort. A számított F-érték $(\mathrm{F}=0,9515)$ meghaladja a kritikus táblázati éréket $\left(\mathrm{F}^{*}=0,6393\right)$, így a varianciák között különbség mutatható ki. A számított $\mathrm{z}$ érték ( $\mathrm{z}=-1,2632)$ abszolút értéke alatta marad $95 \%$-os megbízhatóság mellett $(\mathrm{P}=0,05 ; \mathrm{DF}=55)$ a kritikus z-értéknek $\left(\mathrm{z}^{*}=1,9600\right)$. Tehát a középértékek közötti 0,535 év eltérés statisztikailag nem tekinthető jelentősnek.

\subsection{A cementzónák alapján becsült kor és a RAJNIK-módszer alapján becsült kor össze- hasonlítása}

A cementrétegek alapján becsült kor és az orrsövény elcsontosodásának kapcsolatát 138 özsuta esetében volt lehetőségem vizsgálni (32-33. ábra). A cementzónák és az orrsövény alapján RAJNIK (1977) szerint becsült kor között szoros statisztikailag igazolható kapcsolatot sikerült kimutatni. A korrelációs koefficiens értéke igen magas $(\mathrm{r}=0,8841)$. Az adatsorok varianciáját F-próbával hasonlítottam össze. Mivel a számított F-érték 1,1097 volt, és ez nem érte el a kritikus értéket $\left(\mathrm{F}^{*}=1,3258\right)$, megállapíthatjuk, hogy a varianciák statisztikailag nem különböznek. Középértékek összehasonlítása során számított z-érték z=0,9685 volt, ami nem haladja meg a kritikus z-értéket $\left(z^{*}=1,9600\right)$, így a középértékek is azonosnak tekinthetőek. Mindezek alapján megállapítható, hogy a suták estében az orrsövény vizsgálata az életkorról jól tájékoztat. A cementzónák száma és az orrsövény elcsontosodása alapján becsült kor regreszszióját az alábbiakban mutatom be (34. ábra).

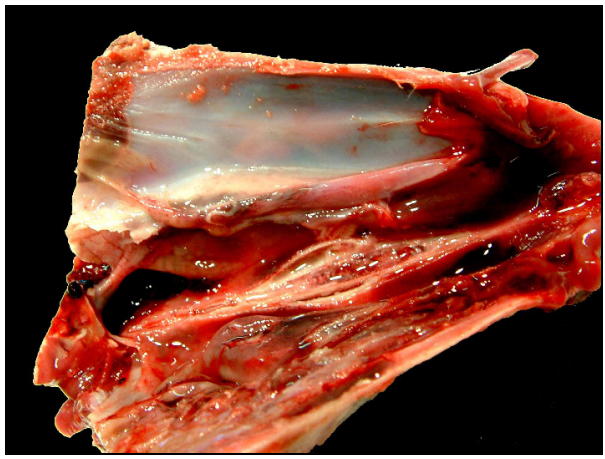

32. ábra: Orrsövény fél éves korban Figure 32: Septum nasi at half years old age

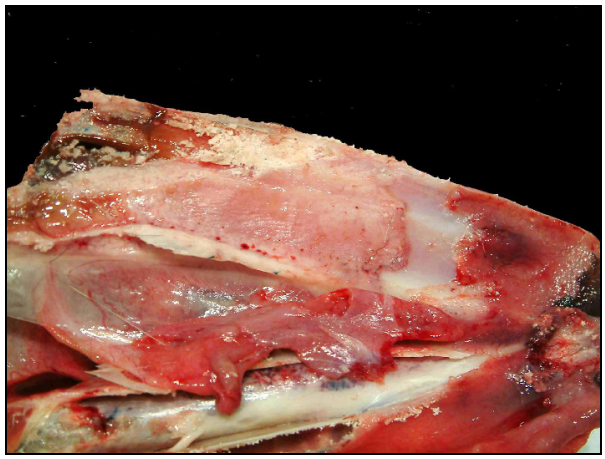

33. ábra: Orrsövény 6 éves korban Figure 33. Septum nasi at 6 years old age

\subsection{A cementzónák száma alapján becsült kor és a mandibuláris zápfogkoronák külső magasságának összehasonlítása}

Mivel a cementzónák száma alapján végzett korbecslés a legpontosabb korbecslési eljárás, ezért ehhez a módszerhez hasonlítottam a korra utaló bélyegeket. A cementzónák száma alapján becsült kor és a mandibuláris zápfogkoronák külső magasságának összehasonlítását 495 őzbak és 138 őzsuta esetében vizsgáltam meg. A cementzónák alapján becsült kor és a hozzá tartozó zápfogkoronák magasságainak összesített adatait a következőkben mutatom be (7-10. táblázat). 


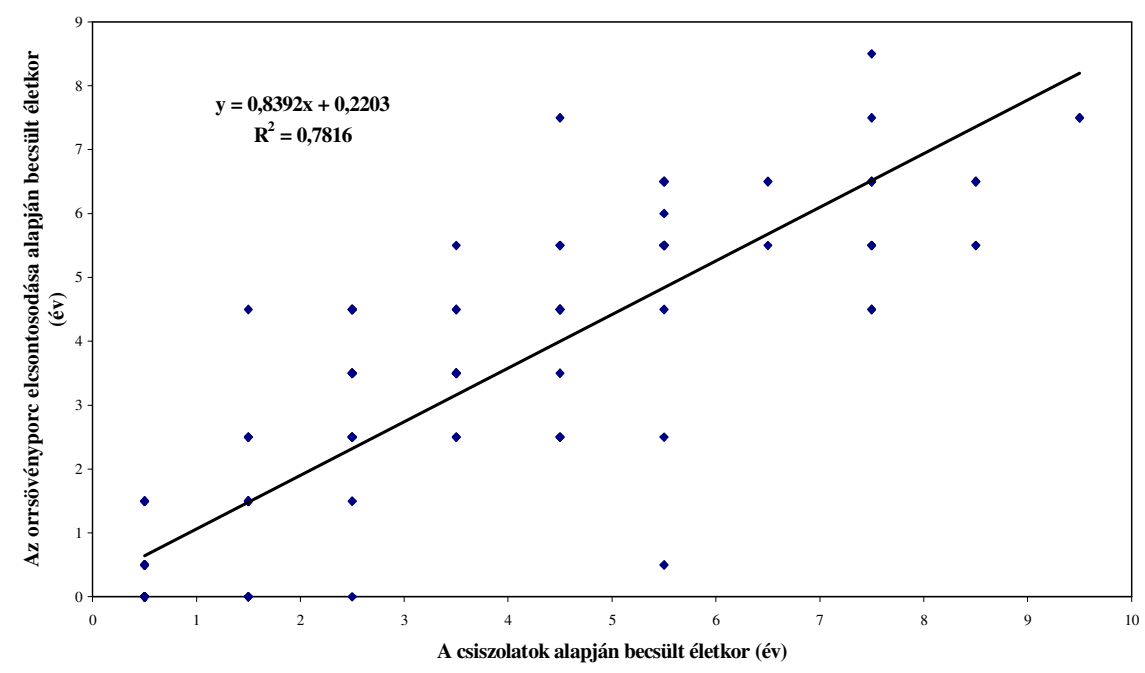

\section{4. ábra: A cementzónák és az orrsövény alapján becsült kor regressziója tolnai őzsutáknál (n=138)}

Figure 34: Regression between age estimation based on cement layers and age estimation based septum nasi at female roe deer

7. táblázat:A cementzónák alapján becsült kor és a hozzátartozó zápfogkoronák magasságainak összesített adatai tolnai őzbakoknál $(n=354)$

Table 7: Summarized data estimated age based on cement layers and height of molarian teeth crowns at roe deer bucks from Tolna County $(n=354)$

\begin{tabular}{|c|c|c|c|c|c|c|c|}
\hline $\begin{array}{c}\text { Cement z. } \\
\text { kor } \\
(\mathbf{e ́ v})\end{array}$ & $\begin{array}{c}\mathbf{P}_{\mathbf{1}} \\
(\mathbf{m m})\end{array}$ & $\begin{array}{c}\mathbf{P}_{\mathbf{2}} \\
(\mathbf{m m})\end{array}$ & $\begin{array}{c}\mathbf{P}_{\mathbf{3}} \\
(\mathbf{m m})\end{array}$ & $\begin{array}{c}\mathbf{M}_{\mathbf{1}} \\
(\mathbf{m m})\end{array}$ & $\begin{array}{c}\mathbf{M}_{\mathbf{2}} \\
(\mathbf{m m})\end{array}$ & $\begin{array}{c}\mathbf{M}_{\mathbf{3}} \\
(\mathbf{m m})\end{array}$ & $\begin{array}{c}\text { Átlag } \\
\mathbf{P}_{\mathbf{1}}-\mathbf{M}_{\mathbf{3}} \\
(\mathbf{m m})\end{array}$ \\
\hline $\mathbf{1}(\mathrm{n}=17)$ & 4,49 & 7,40 & 9,45 & 7,87 & 9,22 & 8,94 & 8,26 \\
\hline $\mathbf{2}(\mathrm{n}=39)$ & 5,15 & 7,07 & 8,53 & 7,00 & 8,41 & 8,26 & 7,40 \\
\hline $\mathbf{3}(\mathrm{n}=71)$ & 4,99 & 6,61 & 8,21 & 6,63 & 7,85 & 7,84 & 7,02 \\
\hline $\mathbf{4}(\mathrm{n}=70)$ & 5,02 & 6,15 & 7,47 & 6,13 & 7,25 & 7,28 & 6,55 \\
\hline $\mathbf{5}(\mathrm{n}=76)$ & 4,87 & 5,53 & 6,56 & 4,94 & 6,20 & 6,28 & 5,73 \\
\hline $\mathbf{6}(\mathrm{n}=32)$ & 4,92 & 5,04 & 5,97 & 4,18 & 5,24 & 5,49 & 5,14 \\
\hline $\mathbf{7}(\mathrm{n}=27)$ & 4,81 & 4,48 & 5,30 & 3,11 & 4,46 & 4,61 & 4,49 \\
\hline $\mathbf{8}(\mathrm{n}=11)$ & 4,86 & 4,04 & 4,83 & 2,44 & 3,64 & 3,79 & 3,92 \\
\hline $\mathbf{9}(\mathrm{n}=11)$ & 4,51 & 3,16 & 3,77 & 1,70 & 2,88 & 2,96 &, 312 \\
\hline $\mathbf{1 0}(\mathrm{n}=2)$ & 4,67 & 3,25 & 3,67 & 1,46 & 2,41 & 2,11 & 2,93 \\
\hline $\mathbf{x}$ & 4,95 & 5,85 & 7,08 & 5,48 & 6,73 & 6,75 & 6,14 \\
\hline Medián & 4,95 & 5,95 & 7,25 & 5,79 & 6,99 & 6,98 & 6,28 \\
\hline Módusz & 5,00 & 5,95 & 6,70 & 6,12 & 7,70 & 8,10 & 7,77 \\
\hline Minimum & 3,10 & 0,75 & 2,50 & 0 & 1,50 & 1,06 & 2,29 \\
\hline Maximum & 6,35 & 8,35 & 10,55 & 9,75 & 10,65 & 11,13 & 10,02 \\
\hline $\mathbf{s}$ & 0,43 & 1,16 & 1,44 & 1,67 & 1,67 & 1,61 & 1,25 \\
\hline Variancia & 0,18 & 1,34 & 2,06 & 2,78 & 2,78 & 2,60 & 1,57 \\
\hline $\mathbf{r}$ & $-0,2394$ & 0,8458 & 0,8992 & 0,9093 & 0,9248 & 0,9006 & 0,9323 \\
\hline r*(P=0,05) & \multicolumn{7}{|c|}{0,1779} \\
\hline $\mathbf{r}$ (2) & 0,0573 & 0,7153 & 0,8085 & 0,8269 & 0,8552 & 0,8110 & 0,8692 \\
\hline f.t. & lin. & par. & par. & par. & par. & par. & par. \\
\hline
\end{tabular}


8. táblázat: A cementzónák alapján becsült kor és a hozzátartozó zápfogkoronák magasságainak összesített adatai tolnai őzsutáknál $(n=138)$

Table 8. Summarized data estimated age based on cement layers and height of molarian teeth crowns at female roe deer from Tolna County $(n=138)$

\begin{tabular}{|c|c|c|c|c|c|c|c|}
\hline $\begin{array}{l}\text { Cement z. } \\
\text { kor } \\
\text { (év) } \\
\end{array}$ & $\begin{array}{l}\mathbf{P}_{1} \\
(\mathbf{m m})\end{array}$ & $\begin{array}{l}\mathbf{P}_{2} \\
(\mathbf{m m})\end{array}$ & $\begin{array}{l}\mathbf{P}_{\mathbf{3}} \\
(\mathbf{m m})\end{array}$ & $\begin{array}{l}\mathbf{M}_{1} \\
(\mathbf{m m})\end{array}$ & $\begin{array}{l}\mathbf{M}_{2} \\
(\mathbf{m m})\end{array}$ & $\begin{array}{l}\mathbf{M}_{3} \\
(\mathbf{m m})\end{array}$ & $\begin{array}{l}\text { Átlag } \\
\mathbf{P}_{1}-\mathbf{M}_{3} \\
(\mathbf{m m}) \\
\end{array}$ \\
\hline $\mathbf{0 , 5}(\mathrm{n}=41)$ & - & - & - & 8,58 & 9,37 & - & - \\
\hline $\mathbf{1 , 5}(\mathrm{n}=17)$ & 4,84 & 6,76 & 8,48 & 6,93 & 8,26 & 8,34 & 7,27 \\
\hline $2,5(n=18)$ & 4,81 & 6,19 & 7,63 & 6,21 & 7,66 & 7,63 & 6,69 \\
\hline $\mathbf{3 , 5}(\mathrm{n}=12)$ & 4,89 & 6,01 & 7,17 & 5,99 & 7,30 & 7,32 & 6,45 \\
\hline $4,5(n=15)$ & 4,80 & 5,35 & 6,78 & 5,18 & 6,59 & 6,57 & 5,87 \\
\hline $\mathbf{5 , 5}(\mathrm{n}=14)$ & 4,93 & 5,10 & 6,06 & 4,40 & 5,73 & 5,84 & 5,32 \\
\hline $6,5(n=2)$ & 4,27 & 3,88 & 4,93 & 2,99 & 4,12 & 4,26 & 4,08 \\
\hline $7,5(\mathrm{n}=11)$ & 4,79 & 3,76 & 4,51 & 2,21 & 3,83 & 4,00 & 3,84 \\
\hline $\mathbf{8 , 5}(\mathrm{n}=5)$ & 3,8 & 3,35 & 4,18 & 2,04 & 3,09 & 2,57 & 3,18 \\
\hline $9,5(n=2)$ & 4,6 & 2,72 & 3,22 & 1,56 & 2,59 & 2,22 & 2,82 \\
\hline $\mathbf{x}$ & 4,79 & 5,42 & 6,66 & 6,08 & 6,49 & 6,43 & 5,77 \\
\hline Medián & 4,70 & 5,60 & 6,85 & 6,21 & 6,97 & 7,02 & 6,11 \\
\hline Módusz & 4,70 & 5,80 & 7,30 & 6,60 & 7,82 & 7,60 & 6,40 \\
\hline Minimum & 2,60 & 2,30 & 2,70 & 0 & 1,85 & 1,12 & 2,73 \\
\hline Maximum & 6,15 & 7,75 & 9,45 & 10,40 & 10,42 & 9,40 & 8,31 \\
\hline $\mathbf{S}$ & 0,51 & 1,29 & 1,57 & 2,29 & 1,87 & 1,89 & 1,39 \\
\hline Variancia & 0,26 & 1,67 & 2,46 & 5,23 & 3,50 & 3,58 & 1,94 \\
\hline $\mathbf{r}$ & $-0,2412$ & 0,8597 & 0,8992 & 0,9310 & 0,9207 & 0,9211 & 0,9347 \\
\hline $\mathbf{r}^{*}(\mathrm{P}=0,05)$ & 0,1779 & & & & & & \\
\hline $\mathbf{r}^{2}$ & 0,0582 & 0,7390 & 0,8085 & 0,8668 & 0,8477 & 0,8484 & 0,8736 \\
\hline f.t. & lin. & par. & par. & par. & par. & par. & par. \\
\hline
\end{tabular}


9. táblázat: A cementzónák alapján becsült kor és a hozzátartozó zápfogkoronák magasságainak összesített adatai hansági őzbakoknál (n=85)

Table 9. Summarized data estimated age based on cement layers and height of molarian teeth crowns at roe deer bucks from Hanság $(\mathrm{n}=85)$

\begin{tabular}{|c|c|c|c|c|c|c|c|}
\hline $\begin{array}{l}\text { Cement } z \text {. } \\
\text { kor } \\
\text { (év) } \\
\end{array}$ & $\begin{array}{l}\mathbf{P}_{1} \\
(\mathbf{m m})\end{array}$ & $\begin{array}{l}\mathbf{P}_{2} \\
(\mathbf{m m})\end{array}$ & $\begin{array}{l}\mathbf{P}_{\mathbf{3}} \\
(\mathbf{m m})\end{array}$ & $\begin{array}{l}\mathbf{M}_{1} \\
(\mathbf{m m})\end{array}$ & $\begin{array}{l}\mathbf{M}_{2} \\
(\mathbf{m m})\end{array}$ & $\begin{array}{l}\mathbf{M}_{3} \\
(\mathbf{m m})\end{array}$ & $\begin{array}{l}\text { Átlag } \\
\mathbf{P}_{1}-\mathbf{M}_{3} \\
(\mathbf{m m}) \\
\end{array}$ \\
\hline $\mathbf{1}(\mathrm{n}=10)$ & 5,34 & 7,20 & 9,00 & 7,41 & 8,72 & 8,75 & 7,87 \\
\hline $2(n=9)$ & 5,31 & 6,77 & 8,52 & 6,86 & 7,84 & 7,90 & 7,25 \\
\hline $3(n=16)$ & 4,97 & 6,23 & 7,85 & 6,09 & 7,35 & 7,20 & 6,62 \\
\hline $4(n=12)$ & 5,19 & 6,03 & 7,14 & 5,36 & 6,52 & 6,39 & 6,12 \\
\hline $5(n=19)$ & 4,88 & 5,32 & 6,48 & 4,84 & 5,81 & 5,74 & 5,51 \\
\hline $6(n=8)$ & 4,94 & 4,87 & 5,75 & 4,26 & 5,18 & 5,26 & 5,04 \\
\hline $7(n=6)$ & 4,83 & 4,73 & 5,17 & 3,03 & 3,92 & 4,01 & 4,28 \\
\hline $8(n=3)$ & 4,90 & 4,43 & 5,10 & 2,34 & 3,83 & 3,86 & 4,08 \\
\hline $9(n=2)$ & 4,85 & 4,75 & 4,80 & 2,20 & 3,05 & 2,95 & 3,77 \\
\hline $\mathbf{x}$ & 5,03 & 5,84 & 7,09 & 5,33 & 6,43 & 6,39 & 6,04 \\
\hline Medián & 5,00 & 5,80 & 7,20 & 5,30 & 6,70 & 6,40 & 6,17 \\
\hline Módusz & 5,00 & 5,00 & 7,80 & 4,40 & 5,20 & 7,35 & 6,48 \\
\hline Minimum & 4,10 & 3,80 & 4,50 & 1,22 & 2,70 & 2,75 & 3,50 \\
\hline Maximum & 6,30 & 8,40 & 10,10 & 8,65 & 10,30 & 9,60 & 8,61 \\
\hline $\mathbf{S}$ & 0,42 & 1,06 & 1,39 & 1,50 & 1,62 & 1,62 & 1,21 \\
\hline Variancia & 0,17 & 1,13 & 1,93 & 2,26 & 2,64 & 2,62 & 1,46 \\
\hline $\mathbf{r}$ & $-0,3266$ & 0,7686 & 0,8903 & 0,9289 & 0,9093 & 0,9059 & 0,9432 \\
\hline $\mathbf{r}^{*}(\mathrm{P}=0,05)$ & 0,2409 & & & & & & \\
\hline $\mathbf{r}^{2}$ & 0,1067 & 0,5907 & 0,7926 & 0,8626 & 0,8269 & 0,8206 & 0,8596 \\
\hline f.t. & lin. & par. & par. & par. & par. & par. & par. \\
\hline
\end{tabular}


10. táblázat: A cementzónák alapján becsült kor és a hozzátartozó zápfogkoronák magasságainak összesített adatai békési őzbakoknál $(n=56)$

Table 10. Summarized data estimated age based on cement layers and height of molarian teeth crowns at roe deer bucks from Békés County $(\mathrm{n}=56)$

\begin{tabular}{|c|c|c|c|c|c|c|c|}
\hline $\begin{array}{l}\text { Cement } \\
\text { z. kor } \\
\text { (év) } \\
\end{array}$ & $\begin{array}{l}\mathbf{P}_{1} \\
(\mathbf{m m})\end{array}$ & $\begin{array}{l}\mathbf{P}_{2} \\
(\mathbf{m m})\end{array}$ & $\begin{array}{l}\mathbf{P}_{\mathbf{3}} \\
(\mathbf{m m})\end{array}$ & $\begin{array}{l}\mathbf{M}_{1} \\
(\mathbf{m m})\end{array}$ & $\begin{array}{l}\mathbf{M}_{2} \\
(\mathbf{m m})\end{array}$ & $\begin{array}{l}\mathbf{M}_{3} \\
(\mathbf{m m})\end{array}$ & $\begin{array}{l}\text { Átlag } \\
\mathbf{P}_{1}-\mathbf{M}_{3} \\
(\mathbf{m m}) \\
\end{array}$ \\
\hline $1(n=7)$ & 4,96 & 8,18 & 9,65 & 7,94 & 9,26 & 8,56 & 8,17 \\
\hline $2(n=5)$ & 4,92 & 6,94 & 8,44 & 7,03 & 8,51 & 8,01 & 7,37 \\
\hline $3(n=6)$ & 5,37 & 6,51 & 8,01 & 6,74 & 8,01 & 8,22 & 7,18 \\
\hline $4(n=10)$ & 5,11 & 6,17 & 7,60 & 6,25 & 7,47 & 7,60 & 6,72 \\
\hline $5(\mathrm{n}=7)$ & 5,32 & 6,20 & 7,13 & 5,22 & 6,23 & 6,54 & 6,11 \\
\hline $6(n=7)$ & 5,04 & 5,65 & 6,10 & 4,43 & 5,54 & 5,67 & 5,38 \\
\hline $7(\mathrm{n}=9)$ & 5,34 & 4,91 & 5,63 & 3,19 & 4,74 & 5,39 & 4,86 \\
\hline $8(n=3)$ & 4,93 & 4,32 & 4,77 & 2,17 & 3,30 & 3,84 & 3,93 \\
\hline $9(\mathrm{n}=2)$ & 5,20 & 3,77 & 4,05 & 1,77 & 2,73 & 2,91 & 3,40 \\
\hline $\mathbf{x}$ & 5,15 & 6,07 & 7,13 & 5,36 & 6,63 & 6,72 & 6,20 \\
\hline Medián & 5,10 & 6,20 & 7,45 & 5,95 & 7,02 & 7,25 & 6,46 \\
\hline Módusz & 4,90 & 6,20 & 7,45 & 6,40 & 7,50 & 7,10 & 7,31 \\
\hline Minimum & 4,10 & 3,70 & 2,60 & 0,60 & 2,40 & 2,30 & 3,34 \\
\hline Maximum & 6,20 & 8,40 & 10,30 & 8,45 & 9,77 & 9,26 & 8,60 \\
\hline $\mathbf{s}$ & 0,46 & 1,28 & 1,66 & 1,93 & 1,97 & 1,68 & 1,37 \\
\hline Variancia & 0,21 & 1,64 & 2,74 & 3,72 & 3,89 & 2,84 & 1,86 \\
\hline $\mathbf{r}$ & $-0,1285$ & 0,8576 & 0,8978 & 0,9438 & 0,9444 & 0,9042 & 0,9519 \\
\hline $\mathbf{r} *(\mathrm{P}=0,05)$ & 0,2616 & & & & & & \\
\hline $\mathbf{r}^{2}$ & 0,0165 & 0,7355 & 0,8061 & 0,8907 & 0,8919 & 0,8176 & 0,9062 \\
\hline f.t. & lin. & par. & par. & par. & par. & par. & par. \\
\hline
\end{tabular}




\section{A becsült kor és a $\mathbf{P}_{\mathbf{1}}$-es fogak kapcsolata}

A $\mathrm{P}_{1}$ az alsó fogsorban előrébb helyeződik, mint a felső fogsorban, ezért a mandibuláris $\mathrm{P}_{1}$ koronáján kopás az első életévekben nem jelentkezik. Később is csak a hátulsó részét érinti a kopás, de előfordul az is, hogy hat, nagyon ritkán hétéves korig nem is látható ezen a részen sem kopás. Ezért nem mutatható ki statisztikailag igazolható kapcsolat. A cementzónák száma alapján becsült kor és a P1-es fog koronamagasságának regresszióját az alábbiakban mutatom be (35. ábra).

\section{A becsült kor és a $\mathbf{P}_{\mathbf{2}}$-es fogak kapcsolata}

A cementum alapján becsült kor és a $\mathrm{P}_{2}$-es fog koronamagasságának kapcsolata statisztikailag

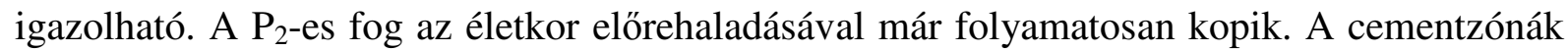
száma alapján becsült kor és a $\mathrm{P}_{2}$-es fog koronamagasságának regresszióját az alábbiakban ábrázoltam (36. ábra).

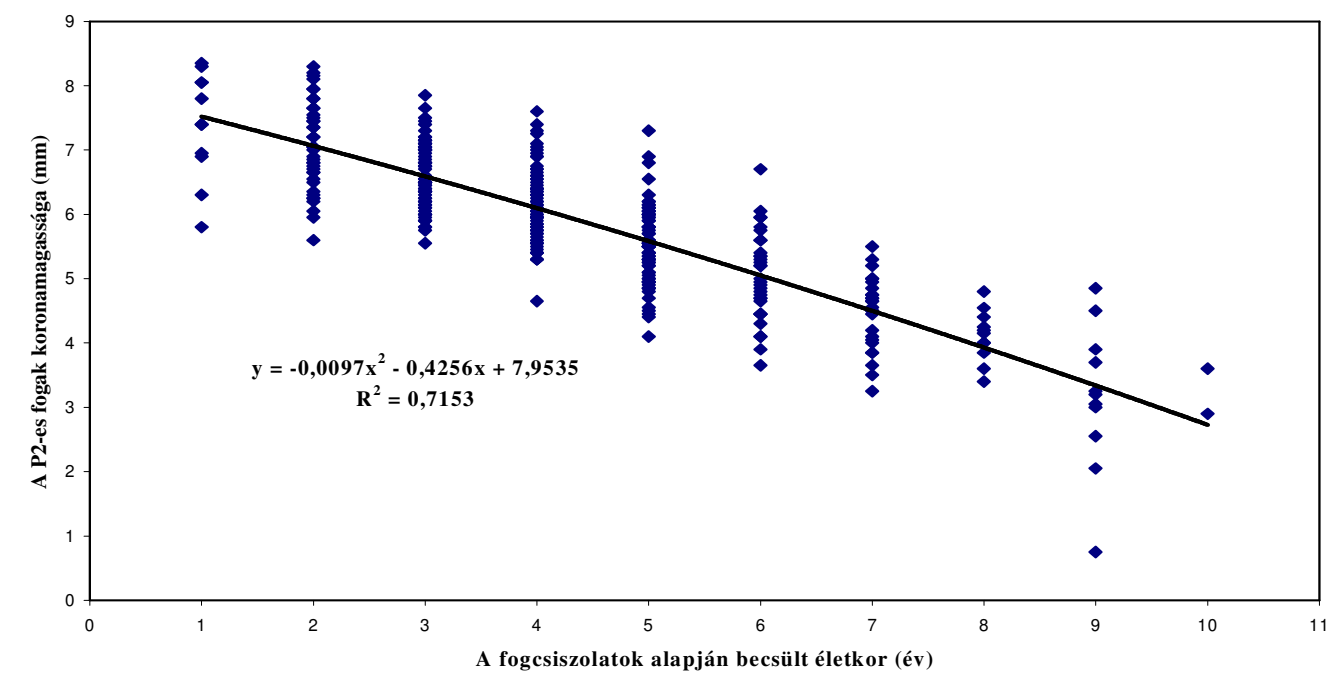

\section{6. ábra: A becsült kor és a $P_{2}$-es fogak koronamagasságának regressziója tolnai bakok- nál $(\mathbf{n}=354)$}

Figure 36. Relationship between age based on cement layer and crown height at $P_{2}(n=354)$

\section{A becsült kor és a $\mathbf{P}_{\mathbf{3}}$-es fogak kapcsolata}

A cementum alapján becsült kor és a $\mathrm{P}_{3}$-as fog koronamagasságának kapcsolata statisztikailag igazolható. Ennek regresszióját az alábbiakban mutatom be (37. ábra). 


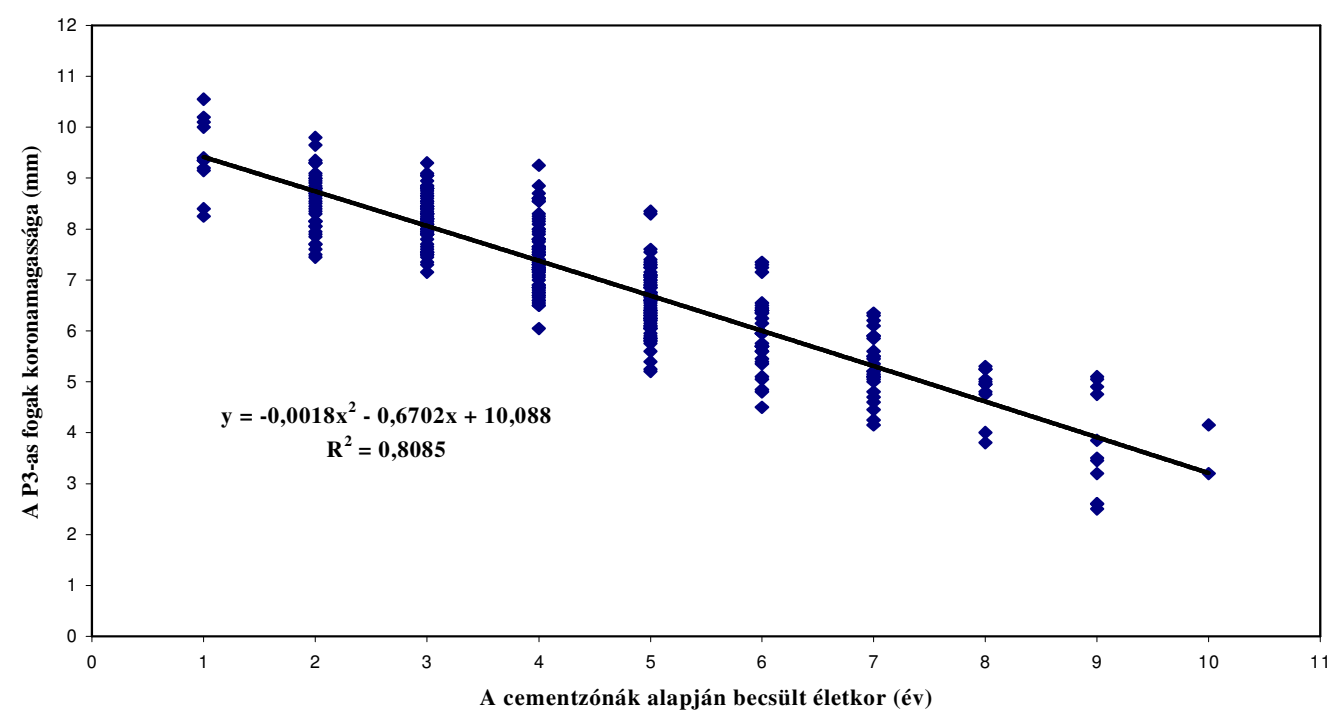

37. ábra: A becsült kor és a $\mathbf{P}_{\mathbf{3}}$-as fogak koronamagasságának regressziója tolnai bakoknál $(\mathbf{n}=354)$

Figure 37. Relationship between age based on cement layer and crown height at $P_{3}(n=354)$

\section{A becsült kor és a $M_{1}$-es fogak kapcsolata}

Az $\mathrm{M}_{1}$-es fog a fogsor közepén helyeződik, kopása az összes fog között a legerösebb, a legjobban korrelál az életkorral. A cementum alapján becsült kor és az $\mathrm{M}_{1}$-es fog koronamagasságának regresszióját az alábbiakban mutatom be (38. ábra).

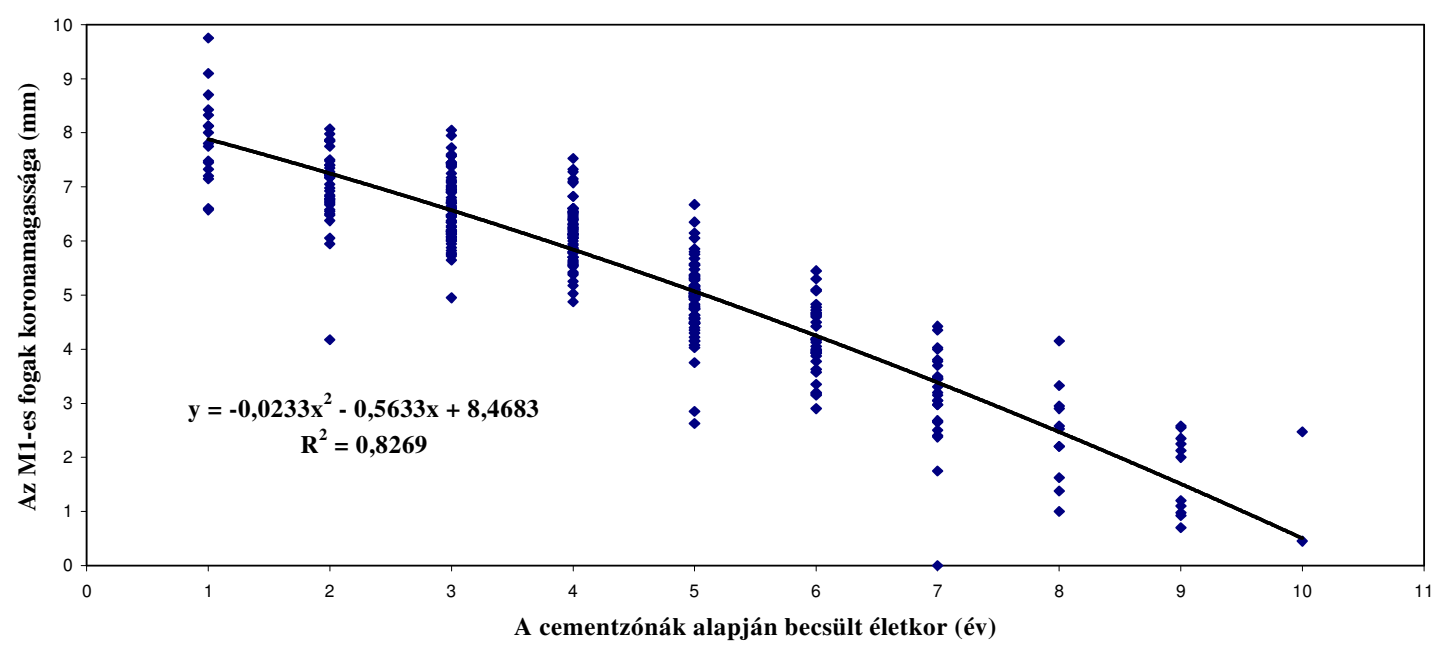

\section{8. ábra: A becsült kor és a $M_{1}$-es fogak koronamagasságának regressziója tolnai ba- koknál ( $(\mathbf{=}=354)$}

Figure 38. Relationship between age based on cement layer and crown height at $M_{1}(n=354)$

\section{A becsült kor és a $M_{2}$-es fogak kapcsolata}

A cementzónák száma alapján becsült kor és az $\mathrm{M}_{2}$-es fog koronamagasságának kapcsolata is igen szoros, gyakorlatilag alig tér el az $\mathrm{M}_{1}$-es fog adataitól. A cementum alapján becsült kor és az $\mathrm{M}_{2}$-es fog koronamagasságának regresszióját az alábbiakban mutatom be (39. ábra). 


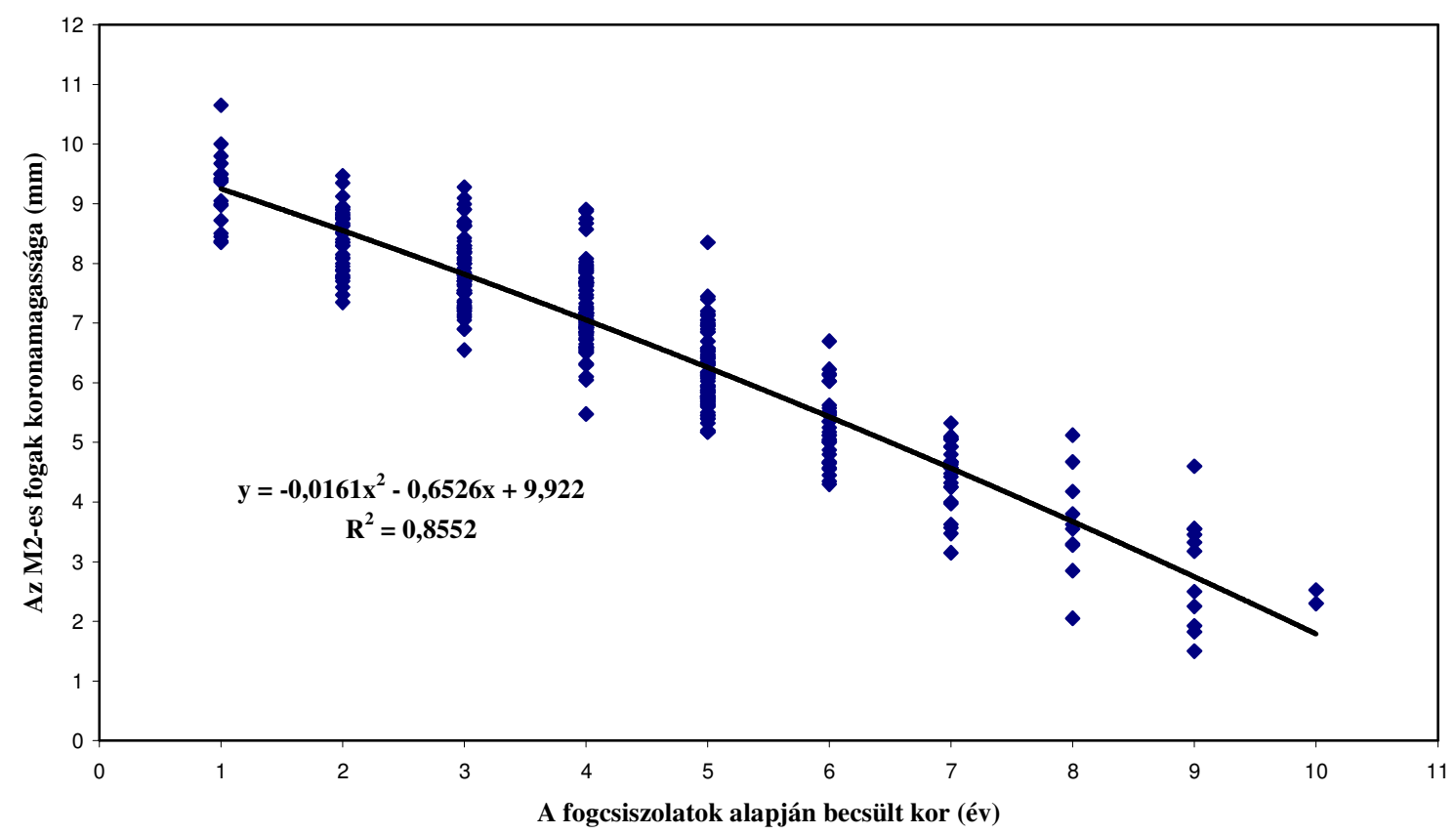

39. ábra: A becsült kor és a $M_{2}$-es fogak koronamagasságának regressziója tolnai bakoknál $(\mathbf{n}=354)$

Figure 39. Relationship between age based on cement layer and crown height at $M_{2}(n=354)$

\section{A becsült kor és a $\mathbf{M}_{\mathbf{3}}$-as fogak kapcsolata}

Az $\mathrm{M}_{3}$-as fog koronamagassága is szoros kapcsolatot mutat a cementum alapján becsült korral. Regresszióját az alábbiakban mutatom be (40. ábra).

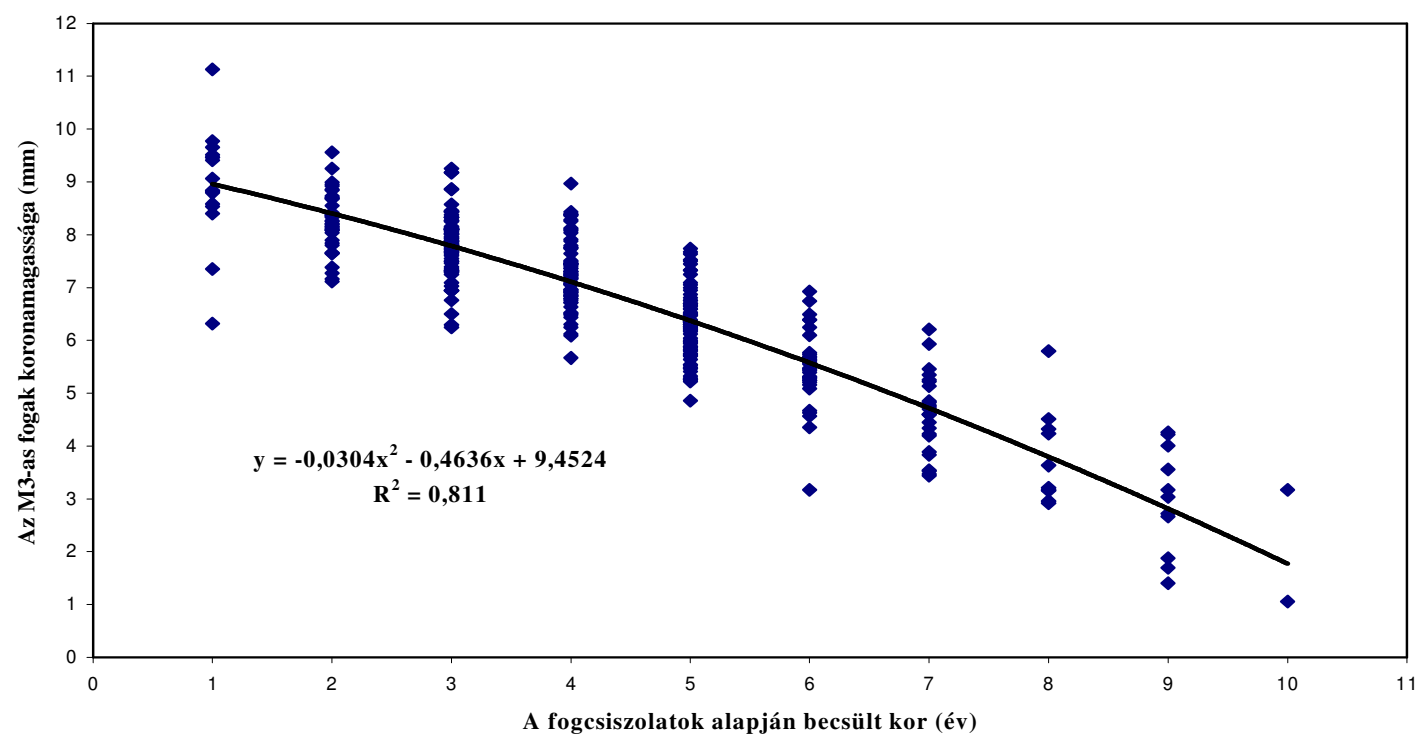

40. ábra: A becsült kor és a $M_{3}$-as fogak koronamagasságának regressziója tolnai bakoknál $(n=354)$

Figure 40. Relationship between age based on cement layer and crown height at $M_{3}(n=354)$ 
A cementzónák száma alapján becsült kor és az alsó fogsori zápfogak koronamagasság-adatainak kapcsolatát regresszió- és korrelációanalízissel vizsgáltam meg. A cementum alapján becsült kor és az összes zápfog - a $\mathrm{P}_{1}$ kivételével - esetében a számított korrelációs koefficiens abszolút értéke meghaladja a $95 \%$-os valószínüség $(\mathrm{P}=0,05 ;)$ mellet a kritikus korrelációs koefficiens érétkét (7.-10. táblázat). A legerősebb az összefüggés az összes zápfogak átlagainál tapasztalható, minden minta esetében $(\mathrm{r}=0,9519 ; 0,9423 ; 0,9347 ; 0,9323)$. Igen erős összefüggés figyelhető meg az $\mathrm{M}_{1}$-nél ( $\left.\mathrm{r}=0,9438 ; 0,9310 ; 0,9289 ; 0,9093\right)$, az $\mathrm{M}_{2}$ nél ( $\mathrm{r}=0,9444 ; 0,9248 ; 0,9207 ; 0,9059)$ és az $\mathrm{M}_{3}$-nál ( $\left.\mathrm{r}=0,9432 ; 0,9211 ; 0,9042 ; 0,9006\right)$ egyaránt. A becsült kor és a moláris fogkoronák magasságának korrelációs koefficiensei hol az egyik, hol a másik fog esetében mutatnak magasabb értéket, de mivel a különbségek elhanyagolhatóak megállapítható, hogy gyakorlatilag azonos szorosságúnak tekinthetőek. A $\mathrm{P}_{3}$-nál kiszámított korrelációs koefficiensek értékei ( $\mathrm{r}=0,8992 ; 0,8992 ; 0,8978 ; 0,8903)$ mindegyik mintában meghaladták a $\mathrm{P}_{2}$-nél számított kofficiensekét $(\mathrm{r}=0,8597 ; 0,8576 ; 0,8458 ; 0,7686)$. Az egyik minta esetében nem volt kimutatható kapcsolat a cementzónák alapján becsült kor és a $\mathrm{P}_{1}$ fogkorona magassága $(\mathrm{r}=-0,1285)$ között. A másik három esetben a számított korrelációs koefficiens értékei meghaladták a számított kritikus együttható értékeit ( $\mathrm{r}=-0,3266$; 0,2412; -0,2394), de ezek a koefficiensek annyira alacsonyak, hogy gyakorlatilag nem tájékoztatnak az életkorról.

Az adatok értékeléséből, a számított statisztikai jellemzőkből és az ábrákból levonható az a következtetés, hogy a mandibuláris zápfogak koronamagasságai igen jól mutatják a kor előrehaladását. A fog koronamagasságát befolyásolják az individuális adottságok (pl.: fogkeménység) és a környezeti tényezők fogkopásgyorsító - mérséklő hatásai (pl.: talaj jellemzők: homok - lösz, Ca-ban szegény - Ca-ban gazdag). A fogkorona magasságának adatai alapján életkort évre pontosan megbecsülni csak kis valószínüségü értékek mellett lehet, de az életkorról jó tájékoztatást nyújt.

\subsection{A cementzónák alapján becsült kor és az I1-es fogak kapcsolata}

A cementzónák alapján becsült kor és az $\mathrm{I}_{1}$-es fogak kapcsolatát 468 őzbak és 90 őzsuta adatainak feldolgozásával vizsgáltam. A cementum alapján becsült kor és az $\mathrm{I}_{1}$-es fogak összesített adatait az alábbiakban mutatom be (11-14. táblázat).

A korrelációs koefficiens számított értékének abszolút értéke minden esetben meghaladja a kritikus korrelációs koefficiens értékét 95 \%-os megbízhatósági szint ( $\mathrm{P}=0,05$; DF=36) mellett. Így a cementum alapján becsült kor és a fogkorona paraméterei között statisztikailag igazolható kapcsolat van.

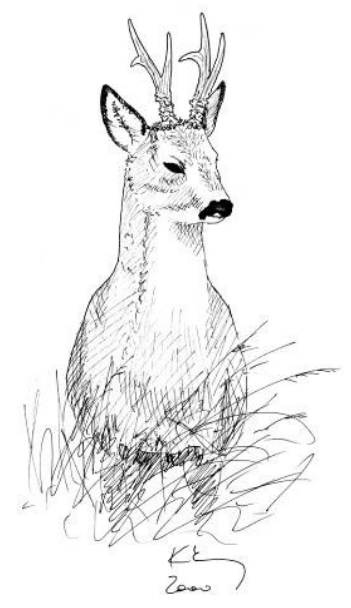




\section{1. táblázat: A cementzónák alapján becsült kor és az $\mathbf{I}_{1}$-es fogak összesített adatai tolnai özbakoknál $(\mathbf{n = 3 3 9})$}

Table 11: Summarized data estimated age based on cement layers and parameter of incisors at roe deer bucks from Tolna County $(\mathrm{n}=339)$

\begin{tabular}{|c|c|c|c|c|c|c|}
\hline $\begin{array}{c}\text { Cement z. kor } \\
\text { (év) }\end{array}$ & $\begin{array}{c}\mathbf{I}_{1} \\
\text { koronamagas- } \\
\text { ság } \\
(\mathbf{m m}) \\
\end{array}$ & $\begin{array}{c}\mathbf{I}_{1} \\
\text { nyakhossz } \\
(\mathbf{m m})\end{array}$ & $\begin{array}{c}I_{1} \\
\text { korona/nyak }\end{array}$ & $\begin{array}{c}\mathrm{I}_{1} \\
\text { kopott } \\
\text { rész } \\
(\mathbf{m m}) \\
\end{array}$ & $\begin{array}{c}\mathbf{I}_{1} \\
\text { korona belső } \\
\text { hossza } \\
(\mathbf{m m}) \\
\end{array}$ & $\begin{array}{c}\mathbf{I}_{1} \\
\text { korona } \\
\text { kopott/belső } \\
(\mathbf{m m}) \\
\end{array}$ \\
\hline $1(n=17)$ & 7,40 & 5,89 & 1,56 & 0,64 & 7,16 & 0,09 \\
\hline $2(n=37)$ & 6,82 & 4,97 & 1,41 & 1,29 & 6,58 & 0,24 \\
\hline $3(n=67)$ & 6,55 & 5,05 & 1,31 & 1,52 & 6,37 & 0,26 \\
\hline $4(n=68)$ & 6,23 & 5,21 & 1,21 & 1,75 & 6,11 & 0,30 \\
\hline $5(n=72)$ & 5,67 & 5,32 & 1,09 & 1,98 & 5,76 & 0,36 \\
\hline $6(n=31)$ & 5,22 & 5,45 & 0,98 & 2,25 & 5,39 & 0,44 \\
\hline $7(n=25)$ & 4,08 & 5,92 & 0,74 & 2,66 & 4,68 & 0,65 \\
\hline $8(n=10)$ & 3,62 & 6,11 & 0,64 & 2,88 & 4,24 & 0,74 \\
\hline $9(n=10)$ & 3,03 & 6,19 & 0,56 & 2,91 & 4,07 & 0,77 \\
\hline $10(n=2)$ & 0,77 & 8,22 & 0,10 & 3,15 & 3,15 & 1,00 \\
\hline $\mathbf{X}$ & 5,84 & 5,29 & 1,17 & 1,84 & 6,18 & 0,35 \\
\hline Medián & 6,10 & 5,20 & 1,17 & 1,75 & 6,45 & 0,29 \\
\hline Módusz & 6,05 & 5,40 & 1,40 & 1,50 & 6,50 & 1,00 \\
\hline Minimum & 0 & 2,85 & 0 & 0,30 & 3,00 & 0,04 \\
\hline Maximum & 8,25 & 9,35 & 5,05 & 4,10 & 8,40 & 1,00 \\
\hline $\mathbf{s}$ & 1,46 & 0,80 & 0,43 & 0,72 & 1,37 & 0,22 \\
\hline Variancia & 2,12 & 0,64 & 0,18 & 0,51 & 1,88 & 0,05 \\
\hline $\mathbf{r}$ & 0,7323 & 0,4920 & 0,7048 & 0,7199 & 0,7092 & 0,7548 \\
\hline $\mathbf{r *}(\mathrm{P}=0,05)$ & \multicolumn{6}{|c|}{0,1779} \\
\hline $\mathbf{r}^{2}$ & 0,5363 & 0,2421 & 0,4968 & 0,5182 & 0,5030 & 0,5697 \\
\hline f.t. & par. & par. & par. & par. & par. & par. \\
\hline
\end{tabular}

\section{2. táblázat: A cementzónák alapján becsült kor és az $I_{1}$-es fogak összesített adatai tolnai őzsutáknál (n=90)}

Table 12: Summarized data estimated age based on cement layers and parameter of incisors at female deer from Tolna County $(\mathrm{n}=90)$

\begin{tabular}{|c|c|c|c|c|c|c|}
\hline $\begin{array}{c}\text { Cement z. kor } \\
\text { (év) }\end{array}$ & $\begin{array}{c}\mathbf{I}_{1} \\
\text { koronamagas- } \\
\text { ság } \\
(\mathrm{mm})\end{array}$ & $\begin{array}{c}\mathbf{I}_{1} \\
\text { nyakhossz } \\
(\mathbf{m m})\end{array}$ & $\begin{array}{c}\mathbf{I}_{1} \\
\text { korona/nyak }\end{array}$ & $\begin{array}{c}\mathbf{I}_{1} \\
\text { kopott } \\
\text { rész } \\
(\mathrm{mm})\end{array}$ & $\begin{array}{c}\mathbf{I}_{1} \\
\text { korona belső } \\
\text { hossza } \\
(\mathrm{mm})\end{array}$ & $\begin{array}{c}\mathbf{I}_{1} \\
\text { korona } \\
\text { kopott/belső } \\
(\mathbf{m m})\end{array}$ \\
\hline $\mathbf{0 , 5}(\mathrm{n}=17)$ & 7,78 & 3,49 & 2,12 & 0,34 & 7,53 & 0,1 \\
\hline $\mathbf{1 , 5}(\mathrm{n}=12)$ & 7,27 & 4,42 & 1,75 & 1,02 & 7,25 & 0,14 \\
\hline $2,5(n=11)$ & 6,71 & 4,34 & 1,60 & 1,35 & 6,88 & 0,20 \\
\hline $\mathbf{3 , 5}(\mathrm{n}=14)$ & 6,54 & 4,69 & 1,41 & 1,69 & 6,48 & 0,7 \\
\hline $\mathbf{4 , 5}(n=10)$ & 5,96 & 4,79 & 1,27 & 2,03 & 5,83 & 0,36 \\
\hline $\mathbf{5 , 5}(\mathrm{n}=10)$ & 5,76 & 4,72 & 1,24 & 2,18 & 5,81 & 0,38 \\
\hline $6,5(n=2)$ & 4,37 & 5,25 & 0,85 & 2,92 & 4,10 & 0,76 \\
\hline $7,5(n=9)$ & 3,31 & 5,57 & 0,70 & 2,91 & 4,19 & 0,75 \\
\hline $8,5(n=2)$ & 3,2 & 6,37 & 0,49 & 3,13 & 3,90 & 0,81 \\
\hline $\mathrm{x}$ & 6,18 & 4,54 & 1,51 & 1,69 & 5,79 & 0,34 \\
\hline Medián & 6,50 & 4,55 & 1,41 & 1,65 & 5,90 & 0,26 \\
\hline Módusz & 6,40 & 4,70 & 1,23 & 1,60 & 6,70 & 1 \\
\hline Minimum & 0 & 1,70 & 0,13 & 0,2 & 3,20 & 0,02 \\
\hline Maximum & 8,90 & 6,85 & 4,82 & 3,6 & 8,10 & 1 \\
\hline $\mathbf{S}$ & 1,74 & 0,94 & 0,70 & ,96 & 1,14 & 0,28 \\
\hline Variancia & 3,03 & 0,89 & 0,50 & 0,93 & 1,30 & 0,08 \\
\hline $\mathbf{r}$ & 0,8564 & 0,7046 & 0,8371 & 0,8790 & 0,8536 & 0,8101 \\
\hline $\mathbf{r} *(\mathrm{P}=0,05)$ & \multicolumn{6}{|c|}{0,2050} \\
\hline $\mathbf{r}^{2}$ & 0,7335 & 0,4964 & 0,7007 & 0,7727 & 0,7285 & 0,6562 \\
\hline f.t. & par. & par. & par. & par. & par. & par. \\
\hline
\end{tabular}




\section{3. táblázat: A cementzónák alapján becsült kor és az $I_{1}$-es fogak összesített adatai lajtai özbakoknál (n=73)}

Table 13: Summarized data estimated age based on cement layers and parameter of incisors at roe deer bucks from Hanság $(\mathrm{n}=73)$

\begin{tabular}{|c|c|c|c|c|c|c|}
\hline $\begin{array}{c}\text { Cement z. kor } \\
\text { (év) }\end{array}$ & $\begin{array}{c}\mathbf{I}_{1} \\
\text { koronamagas- } \\
\text { ság } \\
(\mathrm{mm}) \\
\end{array}$ & $\begin{array}{c}\mathbf{I}_{1} \\
\text { nyakhossz } \\
(\mathbf{m m})\end{array}$ & $\begin{array}{c}\mathrm{I}_{1} \\
\text { korona/nyak }\end{array}$ & $\begin{array}{c}\mathrm{I}_{1} \\
\text { kopott } \\
\text { rész } \\
(\mathrm{mm})\end{array}$ & $\begin{array}{c}\mathbf{I}_{1} \\
\text { korona belső } \\
\text { hossza } \\
(\mathrm{mm})\end{array}$ & $\begin{array}{c}\mathbf{I}_{1} \\
\text { korona } \\
\text { kopott/belső } \\
(\mathbf{m m}) \\
\end{array}$ \\
\hline $1(n=9)$ & 6,88 & 5,03 & 1,39 & 1,43 & 6,76 & 0,25 \\
\hline $2(n=7)$ & 6,64 & 4,93 & 1,37 & 1,41 & 6,43 & 0,23 \\
\hline $3(n=13)$ & 5,98 & 5,31 & 1,15 & 1,91 & 6,22 & 0,31 \\
\hline $4(n=9)$ & 5,90 & 5,51 & 1,09 & 2,14 & 6,00 & 0,37 \\
\hline $5(n=18)$ & 5,39 & 5,61 & 0,97 & 2,06 & 5,55 & 0,40 \\
\hline $6(n=7)$ & 4,93 & 5,43 & 0,84 & 2,71 & 5,17 & 0,59 \\
\hline $7(n=5)$ & 4,94 & 5,86 & 0,71 & 2,70 & 4,74 & 0,64 \\
\hline $8(n=3)$ & 3,77 & 6,30 & 0,62 & 2,70 & 3,87 & 0,72 \\
\hline $9(n=1)$ & 5,40 & 5,60 & 0,96 & 2,60 & 5,60 & 0,46 \\
\hline $\mathbf{x}$ & 5,74 & 5,44 & 1,09 & 2,04 & 5,89 & 0,39 \\
\hline Medián & 5,90 & 5,40 & 1,07 & 1,90 & 6,15 & 0,34 \\
\hline Módusz & 6,60 & 5,40 & 1,12 & 1,60 & 6,30 & 0,18 \\
\hline Minimum & 2,80 & 4,20 & 0,41 & 0,80 & 2,90 & 0,05 \\
\hline Maximum & 8,10 & 7,10 & 1,76 & 3,70 & 7,95 & 1 \\
\hline $\mathbf{S}$ & 1,30 & 0,72 & 0,32 & 0,67 & 1,05 & 0,21 \\
\hline Variancia & 1,70 & 0,51 & 0,10 & 0,44 & 1,09 & 0,05 \\
\hline $\mathbf{r}$ & 0,5487 & 0,3979 & 0,6700 & 0,6002 & 0,6056 & 0,6001 \\
\hline $\mathbf{r}^{*}(\mathrm{P}=0,05)$ & \multicolumn{6}{|c|}{0,2274} \\
\hline $\mathbf{r}^{2}$ & 0,3011 & 0,1583 & 0,4489 & 0,3602 & 0,3668 & 0,3601 \\
\hline f.t. & par. & par. & par. & par. & par. & par. \\
\hline
\end{tabular}

\section{4. táblázat: A cementzónák alapján becsült kor és az $I_{1}$-es fogak összesített adatai béké-} si őzbakoknál $(\mathbf{n}=56)$

Table 14: Summarized data estimated age based on cement layers and parameter of incisors at roe deer bucks from Békés County $(\mathrm{n}=56)$

\begin{tabular}{|c|c|c|c|c|c|c|}
\hline $\begin{array}{c}\text { Cement z. kor } \\
\text { (év) }\end{array}$ & $\begin{array}{c}\mathbf{I}_{1} \\
\text { koronamagas- } \\
\text { ság } \\
(\mathbf{m m}) \\
\end{array}$ & $\begin{array}{c}\mathbf{I}_{1} \\
\text { nyakhossz } \\
(\mathbf{m m})\end{array}$ & $\begin{array}{c}I_{1} \\
\text { korona/nyak }\end{array}$ & $\begin{array}{c}\mathrm{I}_{1} \\
\text { kopott } \\
\text { rész } \\
(\mathbf{m m}) \\
\end{array}$ & $\begin{array}{c}\mathbf{I}_{1} \\
\text { korona belső } \\
\text { hossza } \\
(\mathbf{m m}) \\
\end{array}$ & $\begin{array}{c}\mathbf{I}_{1} \\
\text { korona } \\
\text { kopott/belső } \\
(\mathbf{m m}) \\
\end{array}$ \\
\hline $1(n=7)$ & 7,57 & 4,76 & 1,59 & 0,86 & 7,09 & 0,12 \\
\hline $2(n=5)$ & 6,82 & 5,09 & 1,34 & 0,97 & 6,44 & 0,15 \\
\hline $3(n=6)$ & 6,60 & 5,12 & 1,37 & 1,32 & 6,12 & 0,22 \\
\hline $4(n=10)$ & 6,31 & 4,97 & 1,28 & 1,65 & 6,02 & 0,27 \\
\hline $5(n=7)$ & 6,24 & 5,53 & 1,16 & 2,01 & 5,89 & 0,35 \\
\hline $6(n=7)$ & 5,77 & 5,56 & 1,04 & 1,92 & 5,80 & 0,34 \\
\hline $7(n=9)$ & 5,59 & 5,44 & 1,03 & 2,51 & 4,86 & 0,53 \\
\hline $8(n=3)$ & 3,62 & 6,07 & 0,61 & 2,63 & 4,28 & 0,63 \\
\hline $9(n=2)$ & 2,95 & 6,05 & 0,49 & 2,35 & 4,10 & 0,60 \\
\hline $\mathbf{x}$ & 6,09 & 5,29 & 1,18 & 1,75 & 5,81 & 0,33 \\
\hline Medián & 6,45 & 5,17 & 1,15 & 1,80 & 59 & 0,30 \\
\hline Módusz & 7,00 & 5,00 & 1,15 & 1,90 & 6,40 & 0,15 \\
\hline Minimum & 2,70 & 3,30 & 0,43 & 0,60 & 3,35 & 0,09 \\
\hline Maximum & 7,65 & 7,30 & 2,18 & 3,80 & 7,50 & 0,82 \\
\hline $\mathbf{s}$ & 1,28 & 0,71 & 0,33 & 0,72 & 0,98 & 0,18 \\
\hline Variancia & 1,63 & 0,50 & 0,11 & 0,51 & 0,95 & 0,03 \\
\hline $\mathbf{r}$ & & & & & & \\
\hline $\mathbf{r}^{*}(\mathrm{P}=0,05)$ & \multicolumn{6}{|c|}{0,2593} \\
\hline $\mathbf{r}^{2}$ & 0,6002 & 0,2143 & 0,5895 & 0,6277 & 0,6265 & 0,6858 \\
\hline f.t. & par. & par. & par. & par. & par. & par. \\
\hline
\end{tabular}


A cementzónák alapján becsült kor és az $\mathrm{I}_{1}$-es fogak koronamagasságának regresszióját a tolnai bakok példáján az alábbiakban mutatom be (41. ábra). A korrelációs koefficiens számított értéke (r=0,8564; 0,7747; 0,7323; 0,5847) az őzsutáknál szoros, a bakoknál szoros, közepes és gyenge összefüggés is kimutatható volt a különböző élőhelyeken, annak ellenére, hogy az adatok érdemben nem tértek el egymástól.

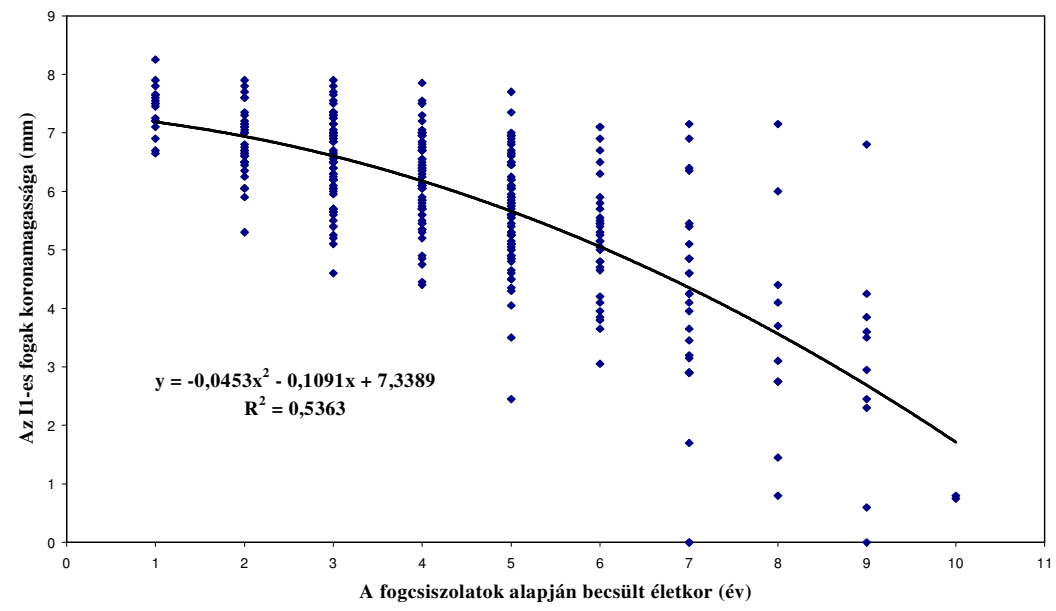

\section{1. ábra: A becsült kor és az $I_{1}$-es fogak koronamagasságának regressziója tolnai ba- koknál (n=339)}

Figure 41: The relationship between estimated age based on cement layers and height of $\mathrm{I}_{1}$ crowns at roe deer buck from Tolna Country $(n=339)$

A cementzónák alapján becsült kor és az $\mathrm{I}_{1}$-es fogak fognyakhosszának regresszióját az alábbiakban ábrázoltam (42. ábra). A korrelációs koefficiens számított értéke ( $\mathrm{r}=0,7046$; 0,6007; 0,4921; 0,4629) közepes és gyenge, de igazolható összefüggést mutat.

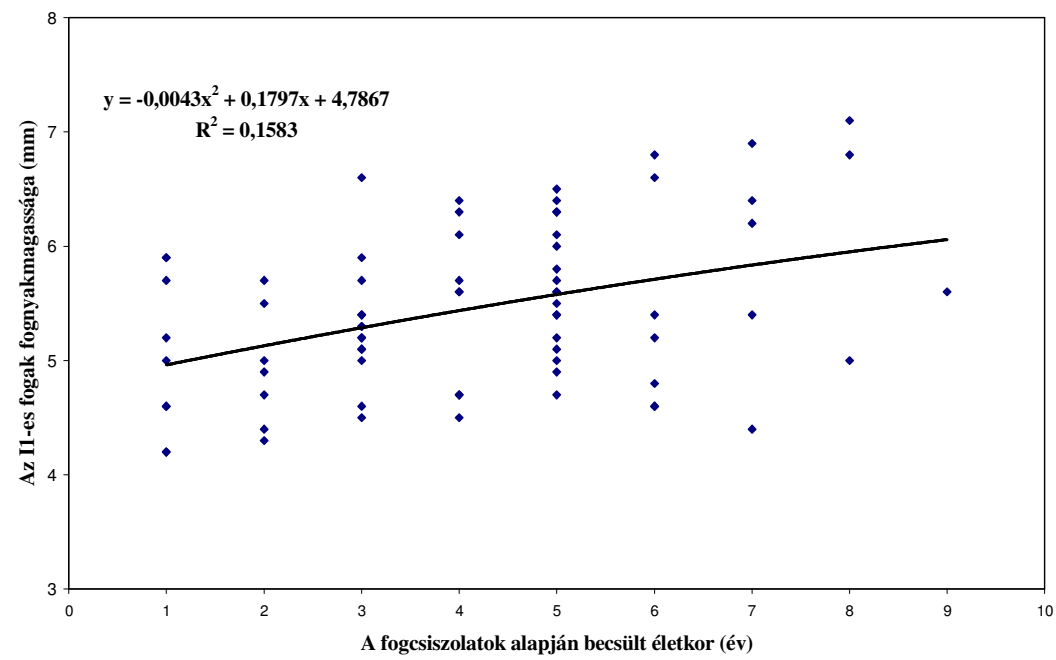

\section{2. ábra: A becsült kor és az $I_{1}$-es fogak fognyakmagasságának regressziója tolnai ba- koknál (n=339)}

Figure 42: The relationship between estimated age based on cement layers and height of $\mathrm{I}_{1}$ necks at roe deer buck from Tolna Country $(n=339)$

A cementrétegek alapján becsült kor és az $\mathrm{I}_{1}$-es fogak fogkorona/fognyakhosszának regresszióját az alábbiakban mutatom be (43. ábra). 


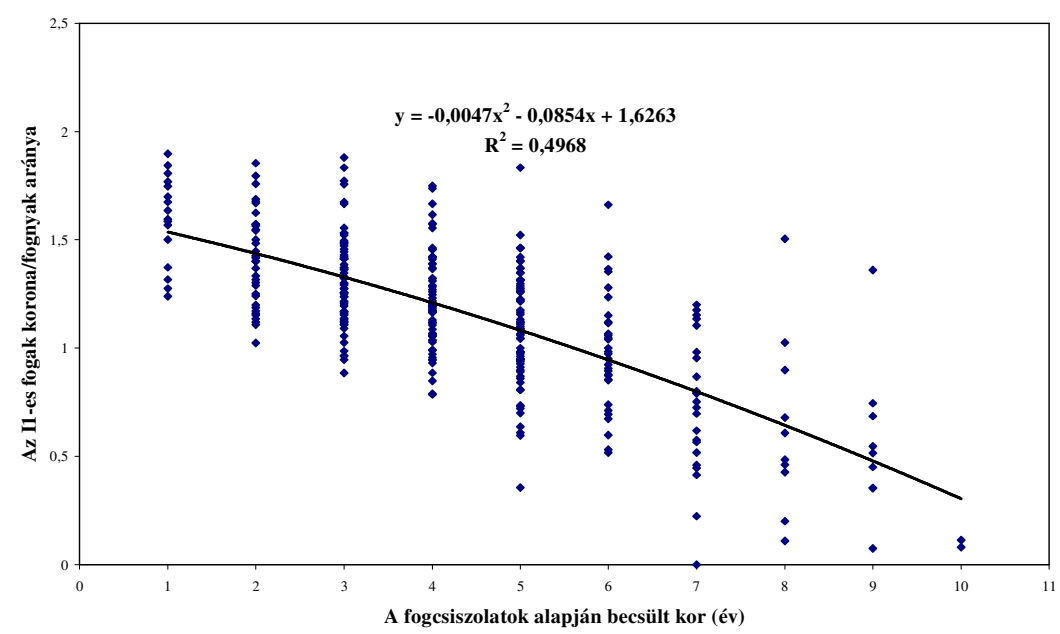

\section{3. ábra: A becsült kor és az $I_{1}$-es fogakkorona/fognyakmagasság arányának regresszió- ja tolnai bakoknál $(n=339)$}

Figure 43: The relationship between estimated age based on cement layers and rates height of $\mathrm{I}_{1}$ crowns/ height of $\mathrm{I}_{1}$ necks at roe deer buck from Tolna Country $(\mathrm{n}=339)$

A korrelációs koefficiens számított értéke (r=0,8368;0,7678;0,7048;0,6700) közepes és gyenge, statisztikailag igazolható összefüggést mutat. A fogkorona és a fognyak arányának korrelációs koefficiens értékei kisebbek, mint a fogkoronáéi, így megállapítható, hogy a fogkorona/fognyak arány értékének ismerete nem tájékoztat jobban a korról, mintha csak a fogkorona hosszát vesszük figyelembe.

A cementrétegek alapján becsült kor és az $\mathrm{I}_{1}$-es fogak lingualis felületén kialakult kopott rész hosszának regresszióját az alábbiakban ábrázoltam (44. ábra). A korrelációs koefficiens számított értéke $(\mathrm{r}=0,8790 ; 0,7923 ; 0,7199 ; 0,6002)$ az özsutáknál erős, a bakoknál közepes és gyenge, statisztikailag igazolható összefüggést mutat. Ha az őzsuták esetében kihagyjuk a fél évesek adatait, úgy ott is közepes erősségü összefüggést kaptunk.

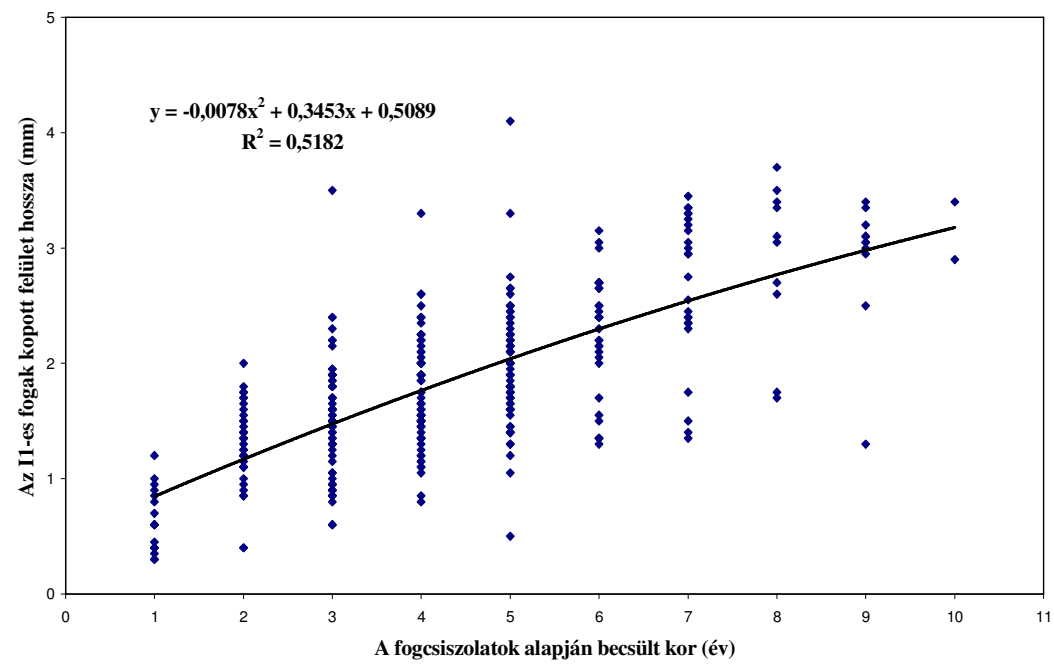

44. ábra: A becsült kor és az $I_{1}$-es fogak lingualis kopott felület hosszának regressziója tolnai bakoknál $(n=339)$

Figure 44: The relationship between estimated age based on cement layers and worn part of facies lingualis at roe deer buck from Tolna Country $(n=339)$ 
A becsült kor és az $\mathrm{I}_{1}$-es fogak lingualis koronamagasságának regresszióját az alábbiakban mutatom be (45. ábra). A korrelációs koefficiens számított értéke ( $\mathrm{r}=0,8535 ; 0,7915 ; 0,7092$; 0,5717) hasonlóan a $\mathrm{I}_{1}$-es fogak lingualis felületén kialakult kopott rész hosszának regressziójához a sutáknál erős, a bakoknál közepes és gyenge, statisztikailag igazolható összefüggést mutat. A suták adataiból, ha elhagyjuk a félévesek értékeit, úgy a bakok adataihoz közelítő, közepes erősségü regressziót kapunk.

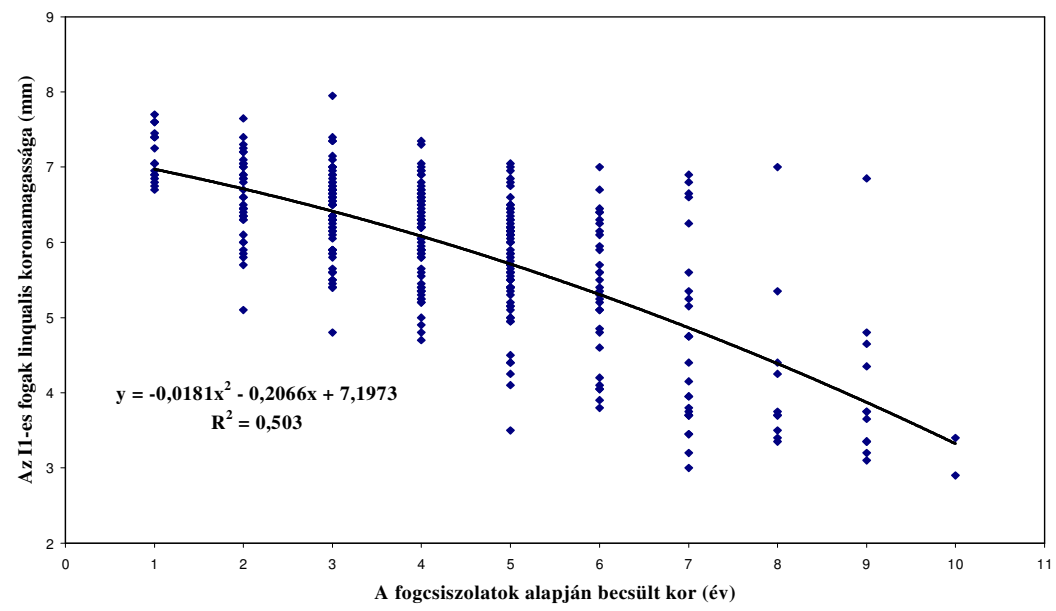

\section{5. ábra. A becsült kor és az $I_{1}$-es fogak lingualis koronamagasságának regressziója tol-} nai bakoknál $(n=339)$

Figure 45: The relationship between estimated age based on cement layers and facies lingualis at roe deer buck from Tolna Country $(n=339)$

A cementrétegek alapján becsült kor és az $\mathrm{I}_{1}$-es fogakon kialakult kopott rész és a korona egész nyelvi felületének arányának regresszióját az alábbiakban ábrázoltam (46. ábra). A korrelációs koefficiens számított értéke $(\mathrm{r}=0,8201 ; 0,8101 ; 0,7548 ; 0,6001)$ közepes és gyenge, de statisztikailag igazolható regressziót mutat. A korrelációs koefficiensek értéke a mintákban felerészt kismértékü emelkedést, felerészt kismértékü csökkenést mutat az $\mathrm{I}_{1}$-es fogak lingualis felületén kialakult kopott rész hosszának vonatkozó értékeihez képest, így megállapítható, hogy az $\mathrm{I}_{1}$-es fogakon kialakult kopott rész és a korona egész nyelvi felületének aránya nem mutat pontosabban az életkort, mintha csak a kopott rész hosszadatait vizsgáljuk.

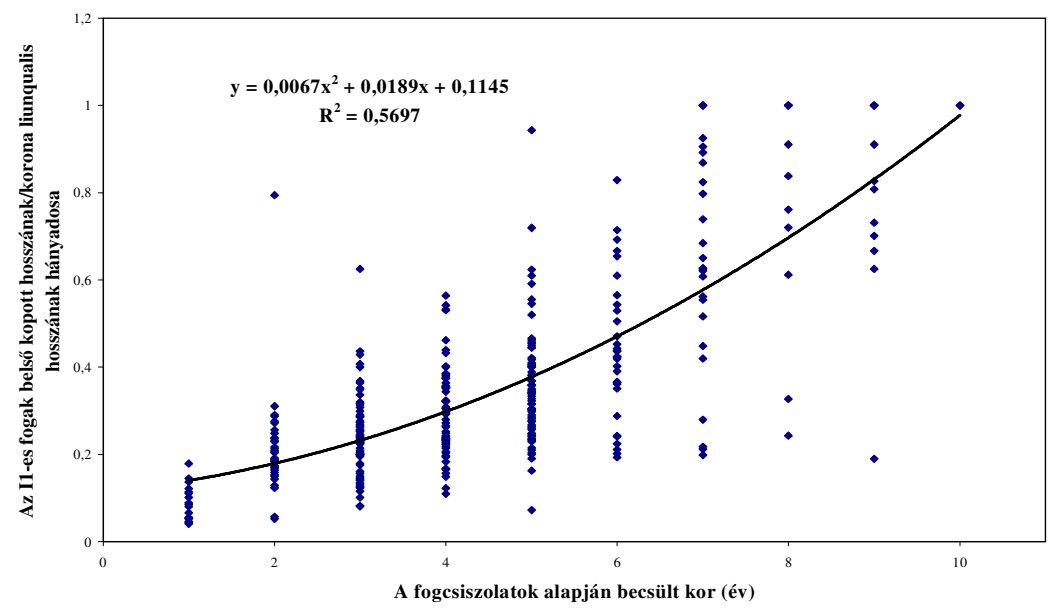

46. ábra. A becsült kor és az $I_{1}$-es fogak lingualis felületén kialakult kopott rész/ koronamagasság regressziója tolnai bakoknál $(n=339)$

Figure 46: The relationship between estimated age based on cement layers and index based on worn part of facies lingualis/total length of facies linguinalis at roe deer buck from Tolna Country $(n=339)$ 
A fentiek alapján megállapítható, hogy a metszöfogak egyetlen hosszúsági paramétere sem mutat olyan szoros regressziót, hogy az életkorról egzakt tájékoztatást nyújtson.

\section{a. A fogszög vizsgálata}

A cementrétegek alapján becsült kor és az $\mathrm{I}_{1}$-es fog szögállásának kapcsolatát 566 adatpár segítségével vizsgáltam meg. A felvett adatok összesítését és feldolgozását az alábbiakban mutatom be (15-17. táblázat).

\section{5. táblázat: A cementzónák alapján becsült kor és az $\mathbf{I}_{1}$-es fogszög kapcsolata ôzbakok- nál}

Table 15: Summarized data estimated age based on cement layers and angle of incisors at roe deer bucks

\begin{tabular}{|c|c|c|c|}
\hline \multirow{2}{*}{$\begin{array}{c}\text { Cement z. } \\
\text { kor } \\
(\text { év) }\end{array}$} & $\begin{array}{c}\text { Tolnai bakok } \\
(\mathrm{n}=345)\end{array}$ & $\begin{array}{c}\text { Lajtai bakok } \\
(\mathrm{n}=77)\end{array}$ & $\begin{array}{c}\text { Békési bakok } \\
(\mathrm{n}=56)\end{array}$ \\
\hline & \multicolumn{3}{|c|}{$I_{1}$ fogszög $\left(^{0}\right)$} \\
\hline 1 & $54,76(n=17)$ & $60,22(n=9)$ & $55,29(n=7)$ \\
\hline 2 & $56,56(n=39)$ & $54,43(n=7)$ & $56,40(n=5)$ \\
\hline 3 & $55,98(n=69)$ & $57,80(n=15)$ & $58,17(n=6)$ \\
\hline 4 & $57,31(\mathrm{n}=68)$ & $58,54(n=11)$ & $54,00(n=10)$ \\
\hline 5 & $59,24(n=73)$ & $57,94(n=18)$ & $58,61(\mathrm{n}=7)$ \\
\hline 6 & $59,24(n=31)$ & $60,05(n=8)$ & $50,79(n=7)$ \\
\hline 7 & $60,08(n=25)$ & $60,60(n=5)$ & $57,67(n=9)$ \\
\hline 8 & $60,90(n=10)$ & $64,67(n=3)$ & $60,67(n=3)$ \\
\hline 9 & $62,18(n=11)$ & $65,00(n=1)$ & $62,50(n=2)$ \\
\hline 10 & $57,00(n=2)$ & - & - \\
\hline $\mathbf{x}$ & 57,87 & 58,74 & 56,25 \\
\hline Medián & 58,00 & 59,00 & 58,00 \\
\hline Módusz & 54,00 & 59,00 & 58,00 \\
\hline Minimum & 42,00 & 44,00 & 41,00 \\
\hline Maximum & 74,00 & 68,00 & 68,00 \\
\hline $\mathbf{s}$ & 5,58 & 5,03 & 5,30 \\
\hline Variancia & 31,08 & 25,30 & 28,10 \\
\hline $\mathbf{r}$ & 0,2844 & 0,1393 & 0,1063 \\
\hline $\mathbf{r} *(\mathrm{P}=0,05)$ & 0,1779 & 0,2216 & 0,2593 \\
\hline $\mathbf{r}^{2}$ & 0,0809 & 0,0194 & 0,0113 \\
\hline f.t. & $\log$. & $\log$. & $\log$. \\
\hline
\end{tabular}


16. táblázat: A cementzónák alapján becsült kor és az $I_{1}$-es fogszög kapcsolata őzsutáknál

Table 16: Summarized data estimated age based on cement layers and angle of incisors at female roe deer

\begin{tabular}{|c|c|}
\hline $\begin{array}{l}\text { Cement z. kor } \\
\text { (év) }\end{array}$ & $\begin{array}{c}\mathrm{I}_{1} \text { fogszög }\left(^{\mathbf{0}}\right) \text { tolnai ózsutáknál } \\
\qquad(\mathrm{n}=88)\end{array}$ \\
\hline $\mathbf{0 , 5}(\mathrm{n}=16)$ & 45,94 \\
\hline $\mathbf{1 , 5}(\mathrm{n}=12)$ & 51,33 \\
\hline $2,5(n=12)$ & 50,91 \\
\hline $\mathbf{3 , 5}(\mathrm{n}=9)$ & 53,44 \\
\hline $4,5(n=13)$ & 47,38 \\
\hline $\mathbf{5 , 5}(\mathrm{n}=10)$ & 50,80 \\
\hline $6,5(n=3)$ & 58,33 \\
\hline $7,5(n=9)$ & 56,78 \\
\hline $8,5(n=3)$ & 54,33 \\
\hline $9,5(n=1)$ & 64,00 \\
\hline $\mathrm{x}$ & 50,91 \\
\hline Medián & 51,00 \\
\hline Módusz & 51,00 \\
\hline Minimum & 33,00 \\
\hline Maximum & 71,00 \\
\hline $\mathbf{S}$ & 7,03 \\
\hline Variancia & 49,46 \\
\hline $\mathbf{r}$ & 0,3755 \\
\hline $\mathbf{r} *(\mathrm{P}=0,05)$ & 0,2074 \\
\hline $\mathbf{r}^{2}$ & 0,1410 \\
\hline f.t. & $\log$. \\
\hline
\end{tabular}

17. táblázat: A cementzónák alapján becsült kor és az $\mathbf{I}_{1}$-es fogszög kapcsolatának statisztikai jellemzői őzsutáknál a félévesek kihagyásával

Table 17: Summarized data estimated age based on cement layers and angle of incisors at female roe deer missed half years olds

\begin{tabular}{|l|c|}
\hline \multicolumn{1}{|c|}{$\begin{array}{c}\text { Cement z. kor } \\
(\text { év })\end{array}$} & $\begin{array}{c}\mathbf{I}_{\mathbf{1}} \text { fogszög } \mathbf{(}^{\mathbf{0}} \text { ) tolnai ózsutáknál a } \\
\text { félévesek kihagyásával } \\
(\mathrm{n}=72)\end{array}$ \\
\hline $\mathbf{x}$ & 52,01 \\
\hline Medián & 51,00 \\
\hline Módusz & 50,00 \\
\hline Minimum & 38,00 \\
\hline Maximum & 71,00 \\
\hline $\mathbf{s}$ & 6,24 \\
\hline Variancia & 39,00 \\
\hline $\mathbf{r}$ & 0,2156 \\
\hline $\mathbf{r} *(\mathrm{P}=0,05)$ & 0,2290 \\
\hline $\mathbf{r}^{2}$ & 0,0465 \\
\hline f.t. & log. \\
\hline
\end{tabular}


A cementum alapján becsült kor és a fogszög kapcsolatát jellemző korrelációs koefficiens számított értéke a bakok esetében csak a tolnai mintában és csak igen kis mértékben $(\mathrm{r}=0,2844)$ haladja meg a kritikus értéket, ahol a mintaelemszám is igen magas $(\mathrm{n}=345)$. A másik két minta korrelációs koefficiense ( $\mathrm{r}=0,1393 ; 0,1063)$ nem éri el a 95\%-os megbízhatóság mellett a kritikus korrelációs koefficiens értékét, így ezekben az esetekben statisztikailag igazolható kapcsolat nem mutatható ki. A suták adatait vizsgálva megállapítható, hogy kis mértékben meghaladja a számított korrelációs koefficiens ( $\mathrm{r}=0,3755)$ a kritikus táblázati értéket, így gyenge statisztikailag igazolható kapcsolat megállapítható. A számításokat elvégeztem a fél évesek kihagyásával is, és ebben az esetben a korrelációs koefficiens ( $\mathrm{r}=0,2156)$ már alatta marad a kritikus értéknek. Ebböl levonható az a következtetés, hogy a suták esetében egy éves kor után nem növekszik statisztikailag kimutatható módon az $\mathrm{I}_{1}$-es fogak szöge. A becsült kor és az $\mathrm{I}_{1}$-es fogak szögének regresszióját az alábbiakban mutatom be (47. ábra) a tolnai bakok mintáján.

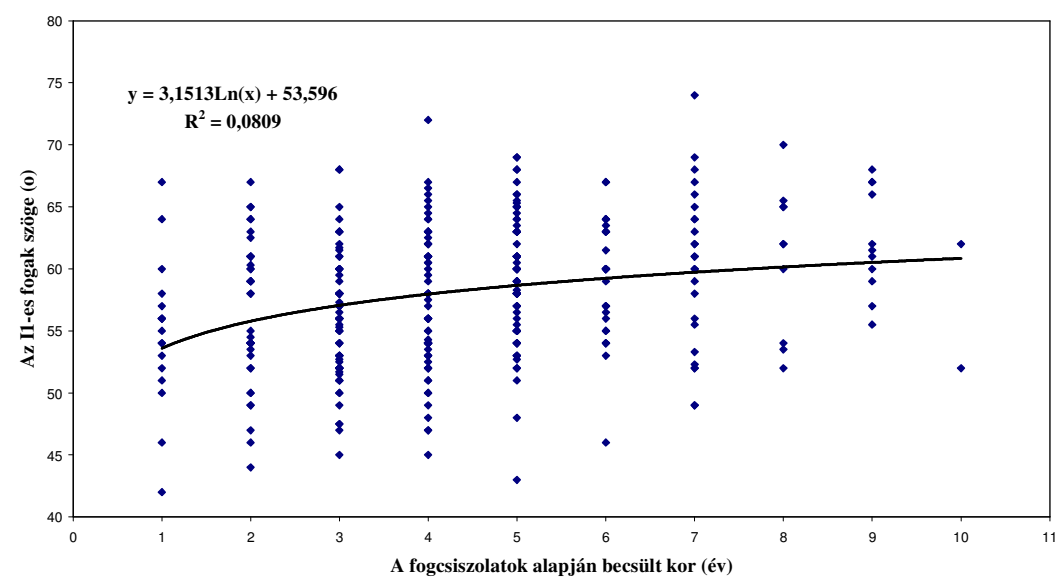

47. ábra: A becsült kor és az $I_{1}$-es fogak szögének regressziója tolnai bakoknál ( $\left.n=345\right)$

Figure 47: Relationship between estimated age based on cement layers and angle of incisors at roe deer buck from Tolna Country $(n=345)$

\section{b. A cementzónák alapján becsült kor és a fogsorhossz kapcsolata}

A cementum alapján becsült kor és a mandibuláris fogsorhossz kapcsolatának vizsgálatát 498 őzbak és 127 őzsuta adatai alapján végeztem el, melynek eredményeit az alábbiakban mutatom be (18-20. táblázat). 


\section{8. táblázat: A cementzónák alapján becsült kor és a mandibuláris fogsorhossz kapcso- lata őzbakoknál}

Table 18: Summarized data estimated age based on cement layers and length of mandible dentures at roe deer bucks

\begin{tabular}{|c|c|c|c|}
\hline \multirow{2}{*}{$\begin{array}{c}\text { Cement z. kor } \\
\text { (év) }\end{array}$} & $\begin{array}{c}\text { Tolnai bakok } \\
(n=354)\end{array}$ & $\begin{array}{c}\text { Lajtai bakok } \\
(n=89)\end{array}$ & $\begin{array}{c}\text { Békési bakok } \\
(\mathrm{n}=55)\end{array}$ \\
\hline & \multicolumn{3}{|c|}{ Mandibuláris fogsorhossz $(\mathrm{mm})$} \\
\hline 1 & $69,32(n=17)$ & $67,15(n=10)$ & $68,46(n=7)$ \\
\hline 2 & $67,05(n=39)$ & $67,09(n=9)$ & $67,65(n=5)$ \\
\hline 3 & $66,87(n=70)$ & $66,92(n=16)$ & $67,38(n=6)$ \\
\hline 4 & $66,59(n=70)$ & $65,19(n=12)$ & $66,41(n=10)$ \\
\hline 5 & $65,08(n=76)$ & $65,63(n=19)$ & $66,05(n=7)$ \\
\hline 6 & $64,12(n=32)$ & $65,70(n=9)$ & $64,74(n=7)$ \\
\hline 7 & $64,38(n=25)$ & $64,70(n=6)$ & $65,78(n=9)$ \\
\hline 8 & $63,42(n=11)$ & $63,30(n=3)$ & $64,02(n=3)$ \\
\hline 9 & $62,09(n=11)$ & $64,30(n=2)$ & $63,90(n=1)$ \\
\hline 10 & $64,37(n=2)$ & - & - \\
\hline $\mathbf{x}$ & 65,79 & 65,86 & 66,31 \\
\hline Medián & 65,90 & 65,95 & 66,35 \\
\hline Módusz & 65,20 & 64,90 & 68,80 \\
\hline Minimum & 38,63 & 60,10 & 62,70 \\
\hline Maximum & 73,80 & 71,30 & 71,05 \\
\hline $\mathbf{s}$ & 3,01 & 2,37 & 2,16 \\
\hline Variancia & 9,03 & 5,62 & 4,65 \\
\hline $\mathbf{r}$ & 0,5411 & 0,4301 & 0,5763 \\
\hline $\mathbf{r}^{*}(\mathrm{P}=0,05)$ & 0,1779 & 0,2062 & 0,2593 \\
\hline $\mathbf{r}^{2}$ & 0,2928 & 0,1850 & 0,3321 \\
\hline f.t. & par. & par. & par. \\
\hline
\end{tabular}

\section{9. táblázat: A cementzónák alapján becsült kor és a mandibuláris fogsorhossz kapcso- lata őzsutáknál}

Table 19: Summarized data estimated age based on cement layers and length of mandible dentures at female roe deer

\begin{tabular}{|l|c|}
\hline $\begin{array}{c}\text { Cement z. kor } \\
(\mathbf{e ́ v})\end{array}$ & $\begin{array}{c}\text { Mandibuláris fogsorhossz tolnai őzsutáknál } \\
(\mathbf{m m}) \\
(\mathrm{n}=127)\end{array}$ \\
\hline $\mathbf{0 , 5}(\mathrm{n}=37)$ & 56,59 \\
\hline $\mathbf{1 , 5}(\mathrm{n}=17)$ & 66,70 \\
\hline $\mathbf{2 , 5}(\mathrm{n}=18)$ & 66,48 \\
\hline $\mathbf{3 , 5}(\mathrm{n}=11)$ & 67,03 \\
\hline $\mathbf{4 , 5}(\mathrm{n}=14)$ & 65,90 \\
\hline $\mathbf{5 , 5}(\mathrm{n}=12)$ & 64,00 \\
\hline $\mathbf{6 , 5}(\mathrm{n}=2)$ & 64,80 \\
\hline $\mathbf{7 , 5}(\mathrm{n}=9)$ & 65,37 \\
\hline $\mathbf{8 , 5}(\mathrm{n}=5)$ & 62,75 \\
\hline $\mathbf{9 , 5}(\mathrm{n}=2)$ & 62,30 \\
\hline $\mathbf{x}$ & 63,06 \\
\hline Medián & 64,80 \\
\hline Módusz & 64,80 \\
\hline Minimum & 50,50 \\
\hline Maximum & 72,40 \\
\hline $\mathbf{s}$ & 5,43 \\
\hline Variancia & 29,50 \\
\hline $\mathbf{r}$ & 0,6492 \\
\hline $\mathbf{r} *(\mathrm{P}=0,05)$ & \\
\hline $\mathbf{r} 2$ & \\
\hline f.t. & \\
\hline
\end{tabular}


20. táblázat: A cementzónák alapján becsült kor és a mandibuláris fogsorhossz kapcsolatának statisztikai jellemzői őzsutáknál a félévesek kihagyásával

Table 20. Summarized data estimated age based on cement layers and length of mandible dentures at female roe deer missed half years old

\begin{tabular}{|l|c|}
\hline \multicolumn{1}{|c|}{$\begin{array}{c}\text { Cement z. kor } \\
\text { (év) }\end{array}$} & $\begin{array}{c}\text { Mandibuláris fogsorhossz tolnai ózsu- } \\
\text { táknál a félévesek kihagyásával (mm) } \\
(\mathrm{n}=90)\end{array}$ \\
\hline $\mathbf{x}$ & 65,89 \\
\hline Medián & 66,20 \\
\hline Módusz & 64,80 \\
\hline Minimum & 58,90 \\
\hline Maximum & 72,40 \\
\hline $\mathbf{s}$ & 2,51 \\
\hline Variancia & 6,30 \\
\hline $\mathbf{r}$ & 0,4195 \\
\hline $\mathbf{r} *(\mathrm{P}=0,05)$ & \\
\hline $\mathbf{r}{ }^{2}$ & 0,1760 \\
\hline f.t. & par. \\
\hline
\end{tabular}

A bakok esetében a korrelációs koefficiensek abszolút értéke $(\mathrm{r}=0,5763 ; 0,5411 ; 0,4301)$ mindhárom esetben meghaladta a kritikus értéket, így a cementzónák alapján becsült kor és a fogsorhosszak között 95 \%-os megbízhatóság mellett gyenge kapcsolat $(\mathrm{P}=0,05)$ igazolható a vizsgált minták alapján. A suták teljes adatsorát vizsgálva kismértékben magasabb korrelációs koefficienst $(\mathrm{r}=0,6492)$ számítottam ki. A félévesek adatainak elhagyásával ugyanezen érték már csak r=0,4195. A cementzónák száma alapján becsült kor és a mandibuláris fogsorhossz kapcsolatát az alábbiakban mutatom be a tolnai bakok mintáján (48. ábra).

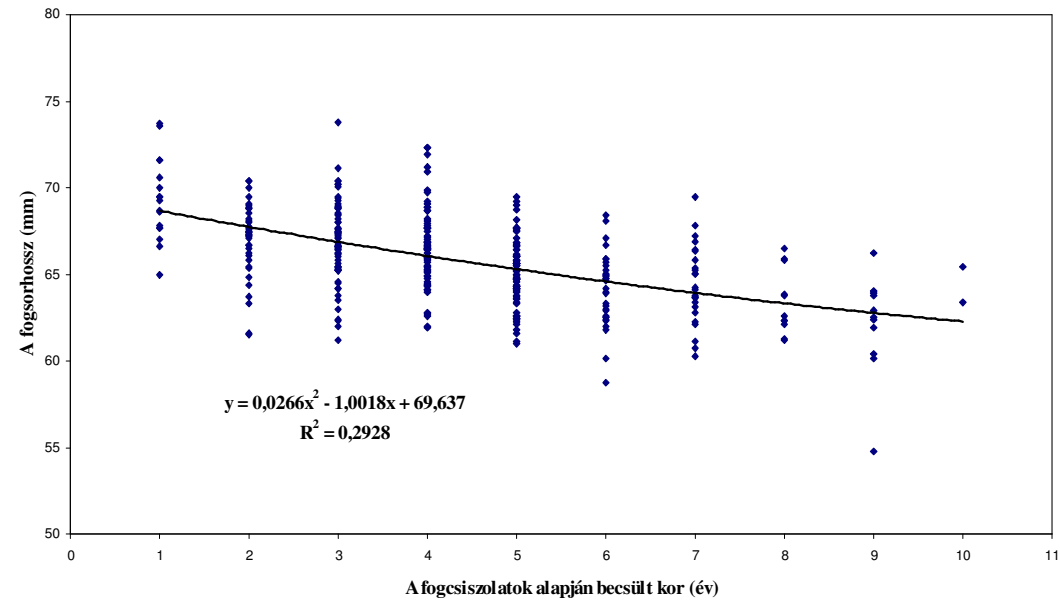

48. ábra. A becsült kor és a fogsorhossz regressziója tolnai bakoknál $(n=354)$

Figure 48: Relationship between age based on cement layer and length of mandible dentures at roe deer bucks $(n=354)$ 


\section{c. A cementrétegek alapján becsült kor és a foghíjas szélhosszának kapcsolata}

A cementrétegek alapján becsült kor és a foghíjas szél hosszának kapcsolatát 433 őzbak és 129 őzsuta esetében vizsgáltam meg. Az adatokat összesítve és értékelve az alábbiakban mutatom be (21-23. táblázat).

\section{1. táblázat: A cementzónák alapján becsült kor és a foghézag hosszának kapcsolata özbakoknál}

Table 21: Summarized data estimated age based on cement layers and length of diasthema at roe deer bucks

\begin{tabular}{|c|c|c|}
\hline \multirow{2}{*}{$\begin{array}{c}\text { Cement z. kor } \\
\text { (év) }\end{array}$} & $\begin{array}{c}\text { Tolnai bakok } \\
(\mathrm{n}=350)\end{array}$ & $\begin{array}{c}\text { Lajtai bakok } \\
(\mathrm{n}=83)\end{array}$ \\
\hline & \multicolumn{2}{|c|}{ Diasthema hossz $(\mathrm{mm})$} \\
\hline 1 & $39,36(n=17)$ & $40,47(n=10)$ \\
\hline 2 & $42,11(n=39)$ & $41,73(\mathrm{n}=9)$ \\
\hline 3 & $42,31(n=71)$ & $41,32(n=16)$ \\
\hline 4 & $43,19(n=70)$ & $41,53(n=11)$ \\
\hline 5 & $42,79(n=74)$ & $42,14(n=18)$ \\
\hline 6 & $43,35(n=31)$ & $42,39(n=9)$ \\
\hline 7 & $43,43(n=25)$ & $43,83(n=6)$ \\
\hline 8 & $42,18(n=11)$ & $43,33(n=3)$ \\
\hline 9 & $44,41(n=10)$ & $43,90(n=1)$ \\
\hline 10 & $43,37(n=2)$ & - \\
\hline $\mathbf{x}$ & 42,66 & 1,87 \\
\hline Medián & 42,75 & 42,00 \\
\hline Módusz & 42,70 & 42,30 \\
\hline Minimum & 30,30 & 37,50 \\
\hline Maximum & 49,90 & 49,30 \\
\hline $\mathbf{s}$ & 2,72 & 2,25 \\
\hline Variancia & 7,40 & 5,04 \\
\hline $\mathbf{r}$ & 0,2811 & 0,3338 \\
\hline $\mathbf{r} *(\mathrm{P}=0,05)$ & 0,1779 & 0,2135 \\
\hline $\mathbf{r}^{2}$ & 0,0790 & 0,1114 \\
\hline f.t. & $\log$. & $\log$. \\
\hline
\end{tabular}




\section{2. táblázat: A cementzónák alapján becsült kor és a mandibuláris fogsorhossz kapcso- lata őzsutáknál}

Table 22: Summarized data estimated age based on cement layers and length of diasthema at female roe deer

\begin{tabular}{|c|c|}
\hline $\begin{array}{c}\text { Cement z. kor } \\
\text { (év) }\end{array}$ & $\begin{array}{c}\text { A diasthemahossz tolnai őzsutáknál } \\
\qquad \begin{array}{c}(\mathbf{m m}) \\
(\mathrm{n}=129)\end{array}\end{array}$ \\
\hline $\mathbf{0 , 5}(\mathrm{n}=38)$ & 34,88 \\
\hline $\mathbf{1 , 5}(\mathrm{n}=16)$ & 39,49 \\
\hline $2,5(n=17)$ & 41,88 \\
\hline $3,5(n=11)$ & 42,03 \\
\hline $4,5(n=15)$ & 41,88 \\
\hline $\mathbf{5 , 5}(\mathrm{n}=13)$ & 41,92 \\
\hline $6,5(n=3)$ & 44,88 \\
\hline $\mathbf{7 , 5}(\mathrm{n}=10)$ & 41,82 \\
\hline $\mathbf{8 , 5}(\mathrm{n}=4)$ & 42,09 \\
\hline $9,5(n=2)$ & 41,32 \\
\hline $\mathbf{x}$ & 39,60 \\
\hline Medián & 4,20 \\
\hline Módusz & 36,60 \\
\hline Minimum & 21,93 \\
\hline Maximum & 46,85 \\
\hline $\mathbf{s}$ & 4,11 \\
\hline Variancia & 16,91 \\
\hline $\mathbf{r}$ & 0,7337 \\
\hline $\mathbf{r} *(\mathrm{P}=0,05)$ & 0,5383 \\
\hline $\mathbf{r}^{2}$ & 0,4215 \\
\hline f.t. & $\log$. \\
\hline
\end{tabular}

\section{3. táblázat: A cementzónák alapján becsült kor és a mandibuláris fogsorhossz kapcso-} latának statisztikai jellemzői őzsutáknál a félévesek kihagyásával

Table 23: Summarized data estimated age based on cement layers and length of diasthema at female roe deer missed half years old

\begin{tabular}{|l|c|}
\hline \multicolumn{1}{|c|}{$\begin{array}{c}\text { Cement z. kor } \\
(\text { év) }\end{array}$} & $\begin{array}{c}\text { A diasthemahossz tolnai őzsutáknál a } \\
\text { félévesek kihagyásával (mm) } \\
(\mathrm{n}=90)\end{array}$ \\
\hline $\mathbf{x}$ & 41,57 \\
\hline Medián & 41,70 \\
\hline Módusz & 40,60 \\
\hline Minimum & 33,05 \\
\hline Maximum & 46,85 \\
\hline $\mathbf{S}$ & 2,68 \\
\hline Variancia & 7,18 \\
\hline $\mathbf{r}$ & 0,2866 \\
\hline $\mathbf{r} *(\mathrm{P}=0,05)$ & 0,2050 \\
\hline $\mathbf{r}$ & 0,0821 \\
\hline f.t. & log. \\
\hline
\end{tabular}

A bakok esetében a számított korrelációs koefficiens értéke (r=0,3338; 0,2811) meghaladja a kritikus korrelációs koefficiens értékét. Így a cementum alapján becsült kor és a foghézag hossza között statisztikailag igazolható gyenge kapcsolat van a bakoknál. A suták teljes adatsora alapján számított korrelációs koefficiens értéke $(\mathrm{r}=0,7337)$ közepes erősségü kapcsolatra utal. A félévesek kihagyásával számított $(\mathrm{r}=0,2866)$ értéke jóval alacsonyabb, a bakokéhoz 
hasonló érték. A becsült kor és a diasthema hossz regresszióját az alábbiakban mutatom be (49. ábra).

d. A cementrétegek alapján becsült kor és a szemlencse tömegének kapcsolata

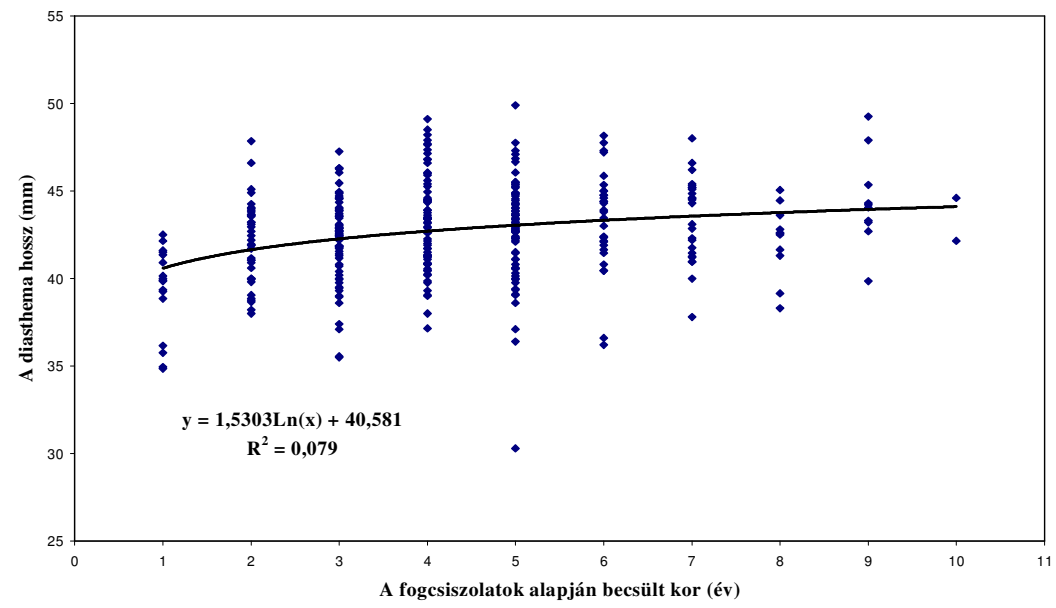

49. ábra. A fogcsiszolatok alapján becsült kor és a diasthema regressziója (n=350)

Figure 49: The relationship between estimated age based on cement layers and length of diasthema at roe deer buck from Tolna Country $(n=339)$

A cementrétegek alapján becsült kor és a szemlencse tömegének kapcsolatát 86 őzbak és 127 őzsuta esetében volt lehetőségem vizsgálni. A fogcsiszolatok alapján becsült kor és a szemlencse nedves, $60{ }^{\circ} \mathrm{C}$-on és $105{ }^{\circ} \mathrm{C}$-on szárított tömegének adatait és az adatsorok föbb statisztikai jellemzőit az alábbiakban mutatom be (24-25. táblázat).

24. táblázat: A cementzónák alapján becsült kor és a szemlencse tömegének kapcsolata özbakoknál

Table 24: Summarized data estimated age based on cement layers and weight of dry eye lenses at roe deer bucks

\begin{tabular}{|c|c|c|c|}
\hline \multirow{2}{*}{$\begin{array}{c}\text { Cement z. kor } \\
\text { (év) }\end{array}$} & \multicolumn{3}{|c|}{$\begin{array}{l}\text { A szemlencse tömege (mg) őzbakoknál } \\
\qquad(n=86)\end{array}$} \\
\hline & $105^{\circ} \mathrm{C}$ & $60^{\circ} \mathrm{C}$ & nedves \\
\hline $\mathbf{1}(\mathrm{n}=10)$ & 310 & 350 & 952 \\
\hline $2(n=9)$ & 295 & 340 & 946 \\
\hline $3(n=16)$ & 334 & 379 & 1051 \\
\hline $4(n=12)$ & 314 & 350 & 1014 \\
\hline $5(n=19)$ & 347 & 390 & 1048 \\
\hline $6(n=9)$ & 330 & 384 & 1035 \\
\hline $7(n=6)$ & 330 & 426 & 996 \\
\hline $8(n=3)$ & 354 & 421 & 1052 \\
\hline $9(n=2)$ & 292 & 318 & 953 \\
\hline $\mathbf{x}$ & 326 & 374 & 1015 \\
\hline Medián & 323 & 255 & 1011 \\
\hline Módusz & 315 & 413 & 1111 \\
\hline Minimum & 168 & 187 & 534 \\
\hline
\end{tabular}


A 24. táblázat folytatása

Table 24 continued

\begin{tabular}{|c|c|c|c|}
\hline \multirow{2}{*}{$\begin{array}{c}\text { Cement z. kor } \\
\text { (év) }\end{array}$} & \multicolumn{3}{|c|}{$\begin{array}{c}\text { A szemlencse tömege (mg) őzbakoknál } \\
(n=86)\end{array}$} \\
\hline & $105^{\circ} \mathrm{C}$ & $60^{\circ} \mathrm{C}$ & nedves \\
\hline Maximum & 457 & 865 & 1727 \\
\hline s & 58 & 97 & 183 \\
\hline Variancia & 3364 & 9409 & 33489 \\
\hline $\mathbf{r}$ & 0,1703 & 0,1738 & 0,1752 \\
\hline $\mathbf{r} *(\mathrm{P}=0,05)$ & \multicolumn{3}{|c|}{0,2100} \\
\hline $\mathbf{r}^{2}$ & 0,0290 & 0,0302 & 0,0307 \\
\hline f.t. & $\log$. & $\log$. & $\log$. \\
\hline
\end{tabular}

\section{5. táblázat: A cementzónák alapján becsült kor és a szemlencse tömegének kapcsolata őzsutáknál}

Table 25: Summarized data estimated age based on cement layers and weight of dry eye lenses at female roe deer

\begin{tabular}{|c|c|c|c|}
\hline \multirow{2}{*}{$\begin{array}{c}\text { Cement z. kor } \\
\text { év }\end{array}$} & \multicolumn{3}{|c|}{ A szemlencse tömege (mg) őzsutáknál } \\
(n=127)
\end{tabular}

A fogcsiszolatok alapján becsült kor és a szemlencse tömegek korrelációs koefficienseinek értékei $(\mathrm{r}=0,1703 ; 0,1738 ; 0,1752)$ a bakok esetében minden esetben alatta maradtak a kritikus korrelációs koefficiensnek, azaz ezek alapján megállapítható, hogy a vizsgált mintában statisztikailag igazolható kapcsolat e két paraméter között nem volt. Mindebböl levonható az a következtetés, hogy a bakok esetében a szemlencse szárazanyag tartalmának növekedése egy éves korig erőteljes, azt követően statisztikailag elhanyagolható mértékü. A becsült kor és a szemlencse $105^{\circ} \mathrm{C}$-on szárított tömegének regresszióját a bakok esetében a 50., suták esetében a 51. ábra mutatja be. 


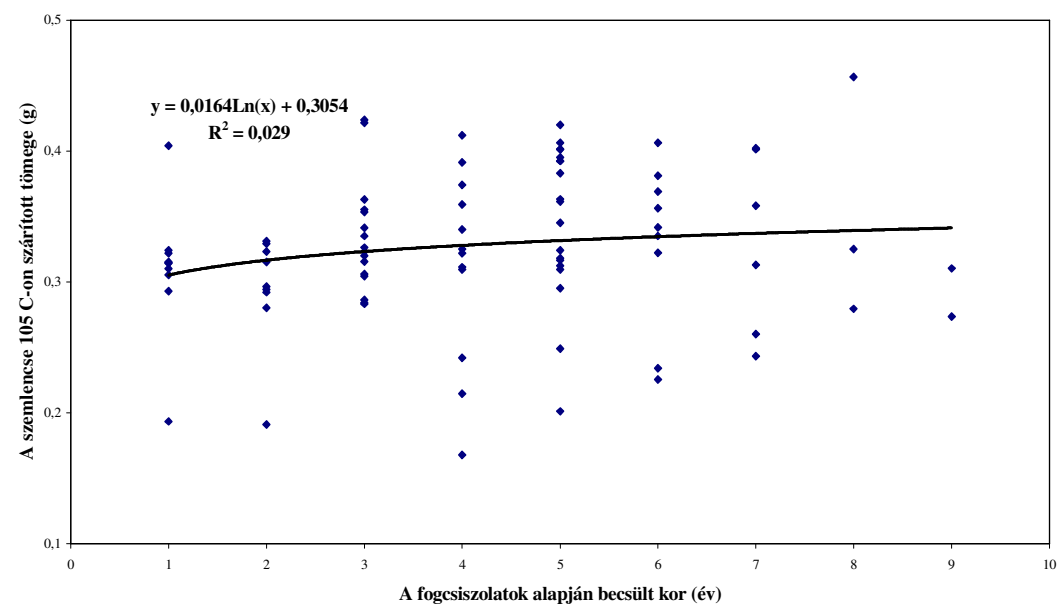

\section{0. ábra. A becsült kor és a szemlencse $105^{\circ} \mathrm{C}$-on szárított tömegének regressziója őz- bakoknál (n=86)}

Figure 50: Relationship between estimated age based on cement layers and weigth of dry eye lenses at roe deer buck $(n=86)$

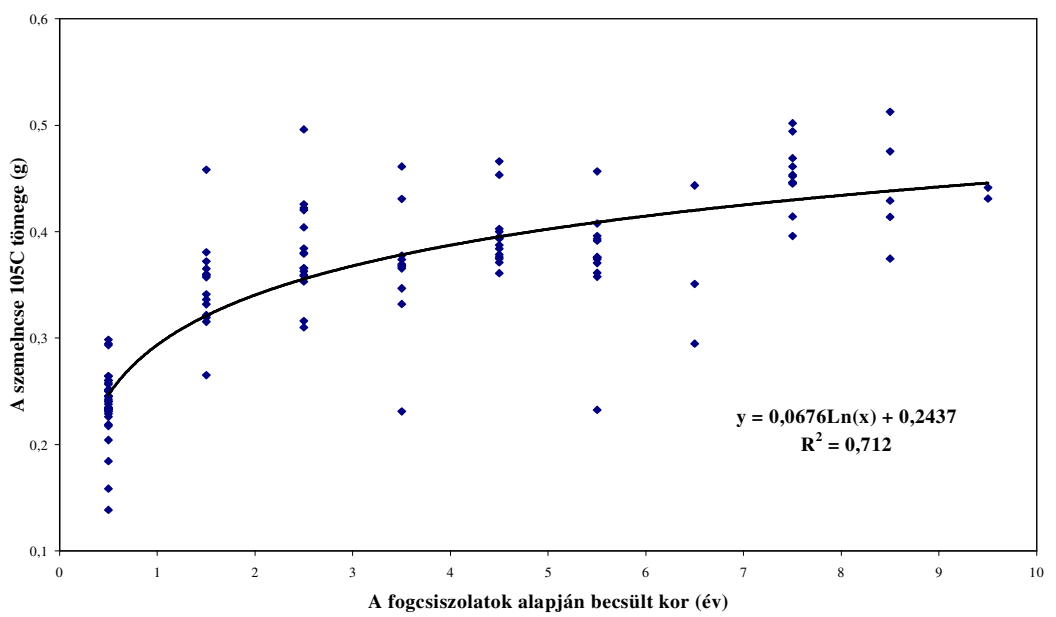

\section{1. ábra. A becsült kor és a szemlencse $105^{\circ} \mathrm{C}$-on szárított tömegének regressziója tolnai özsutáknál (n=127)}

Figure 51: Relationship between estimated age based on cement layers and weight of dry eye lenses at female roe deer $(n=127)$

A suták adatainknak értékelése során számított korrelációs koefficiensek értékei jóval magasabbak (r=0,8438; 0,8349; 0,7694), mint a bakok vonatkozó értékei. Ezek alapján a becsült kor és a szemlencse tömegek között közepes szorosságú, statisztikailag igazolható kapcsolat volt kimutatható. Ennek elsősorban az az oka, hogy a suták mintája tartalmazza a testileg nem kifejlett, fél éves egyedeket is és elsődlegesen ezeknek az egyedeknek köszönhető a relatív magas korrelációs koefficiens. A fogcsiszolatok alapján becsült kor és a $105{ }^{\circ} \mathrm{C}$-on szárított szemlencsetömegek kapcsolatát érékeltem a fél évesek adatainak kihagyásával is. A korrelációs koefficiens ekkor már csupán $\left(\mathrm{r}=0,4840 ; \mathrm{DF}=89 ; \mathrm{r}^{*}=0,2050\right)$ gyenge statisztikailag igazolható kapcsolatot mutat. Amikor a másfél éveseket is kihagytam a számításból a korrelációs koefficiens $\left(\mathrm{r}=0,3933 ; \mathrm{DF}=76 ; \mathrm{r}^{*}=0,2216\right)$ még gyengébb, de még statisztikailag igazolható kapcsolatot mutatott. A két és fél évesek $\left(r=0,4840 ; D F=58 ; r^{*}=0,2523\right)$, a három és fél évesek $\left(r=0,4532 ; D F=47 ; r^{*}=0,2790\right)$ és a négy és fél évesek $(r=0,5626 ; D F=33$; 
$\left.\mathrm{r}^{*}=0,3291\right)$ elhagyásakor még szignifikáns kapcsolat igazolható. Ezt követően az öt és fél évesek $\left(r=0,3209 ; \mathrm{DF}=20 ; \mathrm{r}^{*}=0,4132\right)$, illetve a hat és fél évesek $\left(\mathrm{r}=0,1836 ; \mathrm{DF}=18 ; \mathrm{r}^{*}=0,4329\right)$ elhagyásakor, a vizsgált paraméterek között kapcsolat nem mutatható ki.

A fentiek alapján megállapítható, hogy míg a bakok esetében a szemlencse szárazanyag-tömegének gyarapodása egy éves korra gyakorlatilag megáll, vagy csak rendkívül kis mértékben gyarapszik, addig a suták esetében ez a növekedés, ha kismértékben is de még évekig, körülbelül 5 éves korig elhúzódik.

\section{MEGVITATÁS}

\subsection{Korbecslés a cement- és a dentinállomány növekedési vonalai alapján}

A szakirodalomban (Michell, 1963, 1967; SzABIK, 1973; AitKen, 1975; KovÁCs \& FeleK, 1991; CEDERLUND et al., 1991) általában a mandibuláris $\mathbf{M}_{1}$-es fog korbecslési célú cementum felhasználására találunk javaslatokat. Tapasztalataim alapján is a legjobban értékelhető rétegződés rendre az $\mathrm{M}_{1}$-es fog gyökérívének transzverzális csiszolatán fordult elö, de az $\mathrm{M}_{2}$-es fog transzverzális csiszolatán is jól láthatóak a zónák, az $\mathrm{M}_{3}$-on általában gyengén. Előfordult olyan eset is, hogy a gyökérívben értékelhető rétegződés nem volt megfigyelhető. Ekkor a gyökerek alsó negyedének környékén készített horizontális csiszolaton megfigyelt rétegeket vettem figyelembe, elsősorban az $\mathrm{M}_{1}$-es fogon, de ha ez nem volt értékelhetô úgy ezt a többi fognál is megvizsgáltam. Vizsgálataim szerint - PRIOR (1968) véleményével megegyezőleg - a kihasadó fog nem teljesen kifejlődött gyökerén, a kihasadás évében megfigyelhető a foggyökéren és különösen a gyökérívben a cementállomány képződésének megindulása. Az elsőként kialakuló áttetsző sárga zónában esetenként fehéres beszűrődés is látható. A következő években a cementállomány vastagodásának a vegetációs időszakban fehérszínü, opálos, vastagabb, télen sárgás áttetsző vékonyabb zóna képződik. Így, alátámasztottnak látom saját megfigyeléseim alapján AITKEN (1975) megállapítását, miszerint a fehér zónák megszámolásával megkapjuk az életkort években kifejezve.

A cementum szövettani vizsgálatainak értékelése során úgy találtam, hogy KLEVEZAL \& KLEINENBERG (1967), SZABIK (1973) és KovÁCS \& FELEK (1991) által javasolt haematoxilineosin festés ugyan használható eljárás, de a Giemsával festett metszetek jobban értékelhetőek és az elkészítésük technikai kivitelezése sem nehezebb. A Heidenhain-féle azan, a Goldnerféle trikróm-festés szintén jóval kedvezőbben értékelhető és differenciáltabb képet ad, mint a haematoxilin-eosin, de ezek a festési eljárások ma már a legtöbb orvosi szövettani laborban nem elérhetők, így gyakorlati kivitelezésük nehezebben megvalósítható. A secundaer dentin hisztotechnikai értékeléséről ugyanaz mondható el, mint a cementuméról. A növekedési vonalak száma az általam vizsgált mintában megegyezett a fogcsiszolatok cementuma alapján becsült korral, ami alátámasztja KLEVEZAL \& KLEINENBERG (1967) megállapítását, miszerint a secundear dentin zónáinak száma azonos az őz években kifejezett életkorával.

A cementum életkorbecslési célú elekronmikroszkópos vizsgálatával kapcsolatos szakirodalmi hivatkozást nem találtam, de sajnos ezzel az eljárással zónákat nem sikerült kimutatnom.

\subsection{A fogváltás}

Saját megfigyeléseim szerint a fogváltás az őz 12 hónapos korára befejeződik. Mindezekből következik, hogy a fogváltás alapján csak egyéves korig tudjuk az életkort pontosan becsülni. Ez megerősíti PRIOR (1968) és BIEGER (cit. SZÉKY, 1979) vizsgálatainak eredményét. 


\subsection{A fogkopás}

MEÁK \& SzEDERJEI (1957) szerint a fogkopás alapján becsült kor a tényleges életkorral 70-80 \%-ban is megegyezhet. Vizsgálataim ezt alátámasztják, mivel a fogcsiszolatok cementzónáinak száma alapján becsült kor és a fogkopás alapján becsült kor a bakok esetében különböző populációkban 75,00-87,64 \%-ban egyezik meg. A suták esetében a megegyezés 78,10\% volt. Ezek az adatok nagymértékben közelítenek AITKEN (1975) eredményeihez is, mivel vizsgálatában a cementzónák alapján becsült kor és a fogkopás alapján becsült kor 63,5\%-ban egyezett meg, és 90,5\%-ban egy éven belül volt az eltérés a két módszerrel becsült kor között. Szintén nem mutat jelentős eltérést CEDERLUND et al. (1991) ismert korú egyedek vizsgálatának adataihoz képest.

\subsection{A zápfogak koronamagassága}

StUBBE \& LockOw (cit. VARGA, 1996) az $\mathrm{M}_{1}$-es fogak fogkorona-magassága és a becsült életkor között szoros negatív korrelációt talált, amelynek abszolút értéke $r=0,855$. CEDERLUND et al. (1991) a kor és az $\mathrm{M}_{1}$-es fogak koronamagasságának regressziójánál a korrelációs koefficiens abszolút értéke r=0,66-nak bizonyult. ASHBY \& HENRY (1979) vegyes ivarú őzek vizsgálatakor lineáris regresszióanalízissel jellemezték a becsült kor és a mandibuláris $\mathrm{M}_{1}$-es fogak koronamagasságát. Számításuk szerint korrelációs koefficiens abszolút értéke r=0,86. Ez szoros, statisztikailag igazolható kapcsolatot jelent.

Jelen vizsgálatban ennél némileg szorosabb kapcsolatot találtam az $\mathrm{M}_{1}$-es fogak koronamagasságának vizsgálata során. Vizsgálataim során bakoknál különböző élőhelyeken a korrelációs koefficiens értéke r=0,9093; 0,9289; 0,9438 volt. Sutáknál ennek értéke r=0,9310-nek bizonyult. A szorosabb összefüggés okait az alábbiak ban foglalom össze.

1. Másodfokú regressziót használtam a lineáris helyett, ez önmagában indokolja a szorosabb korrelációs koefficiens értékét.

2. A ivarokat elkülönítve értékeltem.

3. Az analíziseket élőhelyi bontásban értékeltem.

\subsection{A metszőfogak szögállása}

A metszőfogak szögállásának a korral előrehaladó növekedésével kapcsolatosan BIEGER (1939 cit.: MEÁK \& SZEDERJEI, 1957) közölt adatokat. Eredményeit egzaktul nem tudtam saját vizsgálatom eredményeivel összehasonlítani, ugyanis statisztikai feldolgozást nem közölt. Adatai arra utalnak, hogy a metszőfogak dőlésszöge a korral monoton növekedést mutat. Ezt vizsgálataim nem támasztják alá, ugyanis az általam vizsgált populációk egy részében a korrelációs koefficiensek éppen hogy meghaladják a kritikus értéket, más részük ennek alatta van, és az adatsorok relatív szórása is igen magas. Tehát vagy csak rendkívül laza kapcsolat fordult elő vagy nem is volt kimutatható kapcsolat. Így megállapítható, hogy a kor és a metszőfogszög között a gyakorlat számára hasznosan felhasználható, érdemi kapcsolat nincs, s ez a paraméter az életkorról egyedi szinten, gyakorlatilag nem nyújt tájékoztatást.

\subsection{A szemlencse száraz tömege}

MARINGGELE (1979) a becsült kor és a szemlencse száraz tömegének kapcsolatát vizsgálata, és megállapítja a szemlencse száraz tömegének növekedését, de adatai statisztikai értékelését nem végezte el. ANGIBAULT et al. (1993) ismert korú őzek vizsgálata során a kor és a szem- 
lencsetömegek kapcsolatát megvizsgálva rendkívül szoros regressziót mutattak ki. A bakok esetében a korrelációs koefficiens értéke r=0,969, míg a sutáknál r=0,967 volt.

Vizsgálataim során a bakoknál nem sikerült statisztikailag igazolható kapcsolatot kimutatni, a korrelációs koefficiens r=0,1703 volt. Ennek az lehet az oka, hogy bakok esetében csak egyéves és ennél idősebb egyedek vizsgálatát volt lehetőségem elvégezni, és az adatok arra utalnak, hogy egy éves kor felett érdemi szemlencsetömeg növekedés nem tapasztalható. A sutáknál a kor és a $105^{\circ} \mathrm{C}$-on szárított szemlencse tömegének értékelése során $\mathrm{r}=0,8438$-as korrelációs koefficiens értéket számítottam ki. E markáns különbség egyrészről azzal magyarázható, hogy a sutáknál fél év körüli egyedek nagyszámú vizsgálatát is el tudtam végezni, amikor a szemlencse növekedése igen intenzív. Másrészt hozzájárul a különbséghez az is, hogy a sutáknál, ha kis mértékben is, de kimutatható növekedés figyelhető meg kb. 5 éves korig.

\subsection{Az orrsövény elcsontosodása}

Az orrsövény elcsontosodásának segítségével RAJNIK (1977) alapján következtehetünk a korra. A korábbi szakirodalomban a módszer statisztikai jellemzésére nem találunk utalást, csak szubjektív értékelést. Saját vizsgálataim szerint a centzónák száma alapján becsült kor és az orrsövény alapján becsült kor szoros statisztikailag igazolható kapcsolatot mutat a suták esetében. A vizsgálatomban a korrelációs koefficiens értéke r=0,8841-nek bizonyult.

\subsection{A trófeabírálati korbecslés}

A cementum alapján becsült kor és a trófeabírálati kor az egyik mintaterületen 35,96 \%-ban, a másik területen 39,28 \%-ban egyezett meg. Az egyik mintaterületen a maximális eltérés 6 év, a másik területen nyolc év volt. Ezek az adatok némileg szorosabb összefüggést mutatnak, mint KovÁCs \& FELEK (1991) adatai, aminek az lehet az oka, hogy KovÁcs \& FELEK (1991) zárt téri viszonyok között élő őzek vizsgálatával tesztelték e módszer pontosságát és megbízhatóságát. Mivel az őz zárttéri tartása során rendszeresen fellépnek kisebb-nagyobb mértékü magatartási zavarok, továbbá a takarmányozás sem azonos a szabadtéri táplálkozással, feltehető, hogy sem az agancsfejlődés, sem a fogkopás nem lehet azonos a szabadtérivel. Mindezek a tények magyarázzák az adatokban rejlö különbségeket.

\section{KÖVETKEZTETÉSEK ÉS JAVASLATOK}

\subsection{Következtetések és javaslatok a korbecslési módszerek kutatási célú alkalmazásához}

A vadbiológiai kutatások során mindig a vizsgálatok igényességének jellege határozza meg, hogy melyik korbecslési módszert alkalmazzák. Legegyszerübben a trófeabírálati kor alkalmazható, mivel az őzbak trófeájának bírálatakor annak korát is megbecsülik. A fogkopás alapján végzett korbecsléskor ismerni kell a fogkopás morfológiáját, és gyakorlat is szükséges a korbecslés elfogadható pontosságú elvégzéséhez. A cementzónák alapján végzett becsléshez csiszoló berendezés szükséges a preparátumok elkészítéséhez, és sztereó mikroszkóp a preparátumok értékeléséhez. A legpontosabban a szövettani metszetek tájékoztatnak a korról, de a metszetek elkészítéséhez szövettani laboratóriumi háttérre is szükség van. Tehát a pontosság növeléséhez egyre nagyobb idö, energia- és pénzbefektetés szükséges.

Általánosságban javasolható (pl.: szaporodásbiológiai vizsgálatoknál), hogy legalább a fogkopás alapján becsült kort vegyék figyelembe, mert a trófeabírálati korbecslés eredményei pontatlanok, továbbá a nőivarú vad, trófeája nem lévén trófeabírálati korral sem rendelkezik. 
Ha bizonytalanok vagyunk a fogkopás alapján végzett korbecsléskor, akkor inkább lefelé kerekítsük a kort, mivel a gyakorlatban azt legtöbben a fogkopás alapján túlbecsülik cementzónák alapján becsülthöz képest. A fogkopás alapján precízen végzett korbecslés kismértékben tér el a cementzónák alapján becsült kortól, így a vadbiológiai kutatás igényeit általában kielégíti.

Ha a vizsgálatnál igen pontos korra van szükség, javasolható, hogy a cementum alapján végezzék a korbecslést akár csiszolatok, akár hisztotechnikai módszerek segítségével.

\subsection{Következtetések és javaslatok a gyakorlati vadgazdálkodás számára}

Az alábbiakban a gyakorlati vadgazdálkodási tevékenységek végzéséhez használható következtetéseimet foglalom össze.

\subsubsection{Következtetések és javaslatok a terepi korbecsléshez}

A vizsgált mintában a terepen becsült kor aránylag szoros korrelációban volt a cementállomány alapján becsült korral és a fogkopás alapján becsült korral is. A korrelációs koefficiensek nem maradtak el a trófeabírálati kor hasonló korrelációs koefficiensének értékeitől. Ezek szerint a precíz, alapos hivatásos vadász a kort az élő vadnál körülbelül olyan pontosan becsüli, mint a trófeabíráló a trófeán. Javasolható szakképzett, munkáját pontosan és körültekintően végző, a vadállományért és a munkájáért felelősséget érző hivatásos vadász alkalmazása, aki a testtáj arányok, az agancs felépítése, az élöhely és a populáció sajátosságainak figyelembe vételével végzi a terepi korbecslést.

Elmondható, a vizsgált minták alapján, hogy a szakszerűen becsült kor pontossága megfelel a vele szemben elvárt igényeknek.

\subsubsection{Következtetések és javaslatok a trófeabírálati korbecsléshez}

A vizsgálatok eredményeként megállapítható, hogy a cementzónák alapján becsült korhoz a fogkopás alapján becsült kor közelít a legjobban. Ellenben trófeabírálati kor a cementum alapján becsült korral statisztikailag igazolható, de erősnek nem mondható kapcsolatot nem mutatott $95 \%$-os valószínüség mellett.

A trófeabírálati korbecslés pontatlanságának okai, hogy a trófeabírálaton a kort legtöbbször az agancs jellege, a koszorúk és az agancstő dőlése, a koponyacsont vastagsága és a koponyavarratok elcsontosodása alapján becsülik. Mivel e módszerek gyenge, legfeljebb közepes erősségü kapcsolatba hozhatók a korral, a pontos becslést nem teszik lehetővé. A pontatlansághoz hozzájárul a mínusz pontok elkerülésének lehetősége (erre a túlbecsült korok utalnak), a sokszor felületesen végzett bírálat (erre az alul- és a túlbecslés is utal). A kiskoponyás trófeabírálatkor sokszor nem követelik meg a levágott koponyarész bemutatását, vagy azt nem veszik figyelembe. Így a fogkopás mértékének alapulvétele nem tudja pontosítani a becsült kort.

Ezek alapján javasolható, hogy a trófeabírálaton a vadászati hatóság, vagy csak nagy koponyával, vagy a szabályosan kiskoponyára levágott trófeát a levágott rész bemutatásával egyidejüleg bírálja el. Ezt a korábbi vadászati végrehajtási rendelet (30/1997.(IV.30.)FM rendelet) kötelezően elöírta, de sajnálatosan az új 79/2004(V.4.)FVM rendelet ezt nem írja elő. Ezáltal lehetőség van a fogkopás nagyobb hangsúlyú figyelembe vételére, s ez - vizsgálataim szerint - pontosítani fogja a trófeabírálati kort. Tehát a fogsor jelenlétét meg kellene követelni a hivatalos trófeabírálaton és a becsült kor kialakításához a legjelentősebb hangsúllyal érdemes figyelembe venni. Ennek oka a fentieken kívül még az is, hogy a fogazat, mint a táplál- 
kozás nélkülözhetetlen részének elhasználódásának foka, a még várható élettartamot alapvetően meghatározza. Így egyfajta biológiai korként is értelmezhető a fogkopás alapján becsült kor.

Trófeabírálat során a kor megállapítását nem befolyásolja túlzottan az agancs fejlettségi állapota, mivel az egyedek kulminációja sokszor jelentősen eltéró életkorban következik be.

Amennyiben a leírt javaslatok figyelembevételével becsülik a kort a trófeabírálat során, a korbecslési eljárások vizsgálataim szerint pontosabbak lesznek.

\section{0. ÖSSZEFOGLALÁS}

Az őz életkora a hivatásos és a sportvadászt, a vadbiológust és a trófeabírálót egyaránt érdekli. A szakszerü állománykezeléshez elengedhetetlen a korbecslési módszerek ismerete. A hivatalos trófeabírálat során az életkor évre pontos megállapítása kötelező, holott a kort csak egy éves korig lehet pontosan megállapítani (PRIOR, 1994), ettől kezdődően a kort csak becsülni lehet a korbecslési módszerek segítségével.

A munka célja volt annak megállapítása, hogy a magyarországi habitatokban élő őz cement- és pótdentin-állománya létrehoz-e az életkor becslésére alkalmas rétegződéseket. Célom volt továbbá, hogy a korábban szubjektív módon, vélekedéssel értékelt korbecslési módszereket és korra utaló bélyegeket megvizsgáljam, és azok megbízhatóságát és jellemzőit egzakt módon matematikai-statisztikai (biometriai) elemzésnek vessem alá. Ennek eredményeképpen a korbecslési módszerek megbízhatósága és pontossága megállapítható, melynek alapján gyakorlati alkalmazhatóságuk objektív alapokon átgondolható.

Munkámhoz a vizsgálati anyagot, a begyüjtött őzállkapcsok, fejek, illetve az úgynevezett kiskoponya lefürészelése után megmaradt csonkolt koponyák alkották, a hozzátartozó legfontosabb adatokkal. Az állkapcsokat és a koponyákat az ország több élőhelyéről (Tolna, Győr-Moson-Sopron és Békés megyéből) gyüjtöttem be hivatásos vadászok, illetve vadászati felügyelők segítségével. Az állkapcsoknak és a koponyáknak a vizsgálatkor felvettem a korra utaló bélyegek adatait, elvégeztem a fogkopás mértéke alapján a korbecslést. A zápfogak cementállományát és a metszőfogak secundaer dentin- és cementállományát csiszolatkészítéses technikával és hisztotechnikai módszerekkel vizsgáltam meg. Az így nyert adatok segítségével összehasonlítottam, és értékeltem a korbecslési módszereket, és a korra utaló bélyegeket.

A dolgozat legfontosabb megállapításai:

A cementzónák száma alapján az életkort a magyarországi habitatokban élő őzállomány esetében igen jól lehet becsülni. A vizsgált mintában minden esetben meg tudtam becsülni a kort az állkapocs fogainak preparátumaiból.

A csiszolat készítéses technikával a pótdentin alapján végzett korbecslés nem bizonyult alkalmazhatónak mivel a vizsgált mintában a pótdentint bemutató fogcsiszolatpreparátumok nem mutattak az életkorral kapcsolatba hozható rétegződéseket. Ellenben a szövettani vizsgálatok igen jól alkalmazhatónak bizonyultak a pótdentin értékelése során.

A fogkopás alapján végzett korbecslés, ha precízen végzik, nagyon szoros, statisztikailag igazolható korrelációt mutat a cementzónák alapján becsült korral. A bakoknál a különböző mintaterületeken a korrelációs koefficiens 0,$9791 ; 0,9732 ; 0,9691$ volt, míg a suták esetében ez az érték 0,9744.

A békési mintaterületen igen szoros statisztikailag igazolható kapcsolat volt kimutatható a cementzónák alapján becsült kor és a terepen becsült kor között is ( $r=0,9062)$. A tolnai mintaterületen a korrelációs koefficiens értéke érdemben alacsonyabb volt $(r=0,5911)$, de az adatsorok közötti kapcsolat ez esetben is statisztikailag igazolható volt. A két mintaterületen tapasztalt eltérés oka a terepen dolgozó hivatásos vadászok felkészültségében rejlő különbség volt. 
A cementzónák alapján becsült kor és a trófeabírálati korbecslés között közepes erösségü kapcsolat ( $\mathrm{r}=0,6380 ; 0,4882)$ volt kimutatható. Az adatsorok között nem túl markáns különbség mutatkozott meg, s ennek oka a vadászati felügyelők felkészültségének és tapasztalatának különbségeiböl adódott.

A trófeabírálati korbecslés pontatlanságának okaiként megállapítható, hogy mivel a trófeabírálaton a kort legtöbbször az agancs jellege, a koszorúk és az agancstő dőlése, a koponyacsont vastagsága és a koponyavarratok elcsontosodása alapján becsülik és ezek a tulajdonságok gyenge, legfeljebb közepes erősségü kapcsolatba hozhatók a korral, így az életkorra nem utalnak olyan mértékben, hogy ezek alapján pontos kort lehetne becsülni. Mindehhez hozzájárul a mínusz pontok elkerülésének lehetősége (erre a túlbecsült korok utalnak). Sokszor felületes a bírálatkor a kor megállapítása (erre az alul- és a túlbecslés is utal). A kiskoponyás trófeabírálatkor jellemzően nem kötelező a levágott koponyarész bemutatása, tehát a fogkopás mértéke nem figyelhető meg, így nem lehet pontosítani a becsült trófeabírálati kort.

A cementzónák alapján becsült kort és a zápfogak koronamagasságait megvizsgálva megállapítható, hogy a legerősebb összefüggés az összes zápfogak átlagainál tapasztalható, minden minta esetében $(\mathrm{r}=0,9519 ; 0,9423 ; 0,9347 ; 0,9323)$. Igen erős összefüggés figyelhető meg az $\mathrm{M}_{1}$-nél ( $\left.\mathrm{r}=0,9438 ; 0,9310 ; 0,9289 ; 0,9093\right)$, az $\mathrm{M}_{2}$-nél $(\mathrm{r}=0,9444 ; 0,9248 ; 0,9207$; 0,9059) és az $\mathrm{M}_{3}$-nál ( $\left.\mathrm{r}=0,9432 ; 0,9211 ; 0,9042 ; 0,9006\right)$. A becsült kor és a moláris fogkoronák magasságának korrelációs koefficiensei hol az egyik, hol a másik fog esetében mutatnak némileg magasabb értéket, de mivel különbségek elhanyagolhatóak megállapítható, hogy kapcsolatuk a cementum alapján becsült korral gyakorlatilag azonos szorosságúnak tekinthető. A $\mathrm{P}_{3}$-nál kiszámított korrelációs koefficiensek értékei $(\mathrm{r}=0,8992 ; 0,8992 ; 0,8978 ; 0,8903)$ mindegyik mintában meghaladták a $\mathrm{P}_{2}$-nél számított kofficiensekét $(\mathrm{r}=0,8597 ; 0,8576$; 0,8458; 0,7686). Az egyik minta esetében nem volt kimutatható kapcsolat a cementzónák alapján becsült kor és a $\mathrm{P}_{1}$ fogkorona magassága $(\mathrm{r}=0,1285)$ között. A másik három estben a számított korrelációs koefficiens értékei meghaladták ugyan a számított kritikus együttható értékeit ( $\mathrm{r}=0,3266 ; 0,2412 ; 0,2394)$, de ezek a koefficiensek annyira alacsonyak, hogy gyakorlatilag nem tájékoztatnak az életkorról.

A cementzónák alapján becsült kor és az $\mathbf{I}_{\mathbf{1}}$-es fogak külső korona magassága statisztikailag igazolható kapcsolatot mutat. A korrelációs koefficiens számított értéke $(\mathrm{r}=0,8564$; 0,7747; 0,7323; 0,5847) az őzsutáknál szoros, a bakoknál szoros, közepes és gyenge összefüggés is kimutatható volt a különbözö élöhelyeken, annak ellenére, hogy az adatok átlag értékei érdemben nem tértek el egymástól.

A becsült kor és az $\mathbf{I}_{1}$-es fogak fognyakhossza esetében a korrelációs koefficiensek értékei (r=7046; 0,6007; 0,4921;0,4629) közepes illetve gyenge, de igazolható összefüggést mutatnak.

A becsült kor és az $\mathbf{I}_{\mathbf{1}}$-es fogak fogkorona/fognyak arányának korrelációs koefficiensei $(r=0,8368 ; 0,7678 ; 0,7048 ; 0,6700)$ a fogkorona értékeinél alacsonyabbak, a fognyak vonatkozó korrelációs koefficienseinél ellenben magasabb értékeket mutatnak. Mindez alapján megállapítható, hogy a fogkorona/fognyak arány ismerete nem tájékoztat az életkorról jobban, mintha csak a fogkorona hosszát vesszük figyelembe.

A fogcsiszolatok alapján becsült kor és az $\mathbf{I}_{\mathbf{1}}$-es fogak lingualis felületén kialakult kopott rész hosszának korrelációs koefficiensei (r=0,8790;0,7923;0,7199; 0,6002) az özsutáknál erős, a bakoknál közepes és gyenge összefüggéseket mutatnak. A suták estében, ha elhagyjuk a fél évesek adatait, úgy ott is csak közepes erősségü korrelációs koefficienst kapunk.

A becsült kor és az $\mathbf{I}_{\mathbf{1}}$-es fogak koronájának belső (lingualis) magasságának korrelációs koefficienseinek értéke $(\mathrm{r}=0,8535 ; 0,7915 ; 0,7092 ; 0,5717)$ a sutáknál erős, a bakoknál közepes és gyenge, statisztikailag igazolható összefüggést mutat. A suták adataiból, ha elhagyjuk a félévesek értékeit, úgy a bakok adataihoz közelítő, közepes erősségü regressziót kapunk. 
A cementrétegek alapján becsült kor és az $\mathbf{I}_{1}$-es fogakon kialakult kopott rész és a korona egész nyelvi felülete arányának korrelációs koefficiens értékei ( $\mathrm{r}=0,8201 ; 0,8101$; 0,7548; 0,6001) közepes és gyenge, de statisztikailag igazolható regressziót mutatnak. A korrelációs koefficiensek értéke a mintákban felerészt kismértékü emelkedést, felerészt kismértékü csökkenést mutat az $\mathrm{I}_{1}$-es fogak lingualis felületén kialakult kopott rész hosszának vonatkozó értékeihez képest, így megállapítható, hogy az $\mathrm{I}_{1}$-es fogakon kialakult kopott rész és a korona egész nyelvi felületének aránya nem tájékoztat pontosabban az életkorról, mintha csak a kopott rész hosszának adatait vizsgáljuk.

A cementum alapján becsült kor és az $\mathbf{I}_{\mathbf{1}}$-es fogak fogszögének kapcsolatát jellemző korrelációs koefficiens számított értéke a bakok esetében csak a tolnai mintában és csak igen kis mértékben $(r=0,2844)$ haladja meg a kritikus értéket, ahol a mintaelemszám $(n=345)$ is igen magas volt. A másik két minta korrelációs koefficiense $(\mathrm{r}=0,1393 ; 0,1063)$ nem éri el a $95 \%$-os megbízhatóság mellett a kritikus korrelációs koefficiens értékét, így ezekben az esetekben statisztikailag igazolható kapcsolat nem mutatható ki. Mindez azt jelenti, hogy a bakok metszőfogszöge egy éves kor felett gyakorlatilag nem növekszik.

A suták adatait vizsgálva megállapítható, hogy kis mértékben meghaladja a számított korrelációs koefficiens ( $\mathrm{r}=0,3755)$ a kritikus táblázati értéket, így gyenge statisztikailag igazolható kapcsolat megállapítható. A számításokat elvégeztem a fél évesek kihagyásával is, és ebben az esetben a korrelációs koefficiens $(\mathrm{r}=0,2156)$ már alatta marad a kritikus értéknek. Ebböl levonható az a következtetés, hogy a suták esetében egy éves kor után nem növekszik statisztikailag kimutatható módon az $\mathrm{I}_{1}$-es fogak szöge.

A fogcsiszolatok alapján becsült kor és a mandibuláris fogsorhosszak a bakok esetében a korrelációs koefficiensek abszolút értéke $(\mathrm{r}=0,5763 ; 0,5411 ; 0,4301)$ mindhárom esetben meghaladta a kritikus értéket, így a cementzónák alapján becsült kor és a fogsorhosszak között gyenge kapcsolat volt igazolható a vizsgált mintákból. A suták teljes adatsorát vizsgálva kismértékben magasabb korrelációs koefficienst $(\mathrm{r}=0,6492)$ számítottam ki. A félévesek adatainak elhagyásával ugyanezen érték már csak $(\mathrm{r}=0,4195)$ volt.

A becsült kor és a foghíjas szél kapcsolatának értékelésekor a bakok esetében a számított korrelációs koefficiens értéke $(\mathrm{r}=0,3338 ; 0,2811)$ éppen meghaladja a kritikus korrelációs koefficiens értékét. Így a cementum alapján becsült kor és a foghézag hossza között statisztikailag igazolható gyenge kapcsolat van a bakoknál. A suták teljes adatsora alapján számított korrelációs koefficiens értéke ( $\mathrm{r}=0,7337)$ közepes erősségü kapcsolatra utal. A félévesek kihagyásával számított $(\mathrm{r}=0,2866)$ értéke jóval alacsonyabb, a bakokéhoz nagyon hasonló érték.

A fogcsiszolatok alapján becsült kor és a szemlencse tömegek korrelációs koefficienseinek értékei a bakok esetében $(\mathrm{r}=0,1703 ; 0,1738 ; 0,1752)$ minden esetben alatta maradtak a kritikus korrelációs koefficiensnek, azaz ezek alapján megállapítható, hogy a vizsgált mintában statisztikailag igazolható kapcsolat e két paraméter között nem volt. Mindebből levonható az a következtetés, hogy a bakok esetében a szemlencse szárazanyag tartalmának növekedése egy éves korig erőteljes, azt követően statisztikailag elhanyagolható mértékü. A suták adatainknak értékelése során számított korrelációs koefficiensek értékei jóval magasabbak $(\mathrm{r}=0,8438 ; 0,8349 ; 0,7694)$, mint a bakok vonatkozó értékei. Ezek alapján a becsült kor és a szemlencse tömegek között közepes szorosságú, statisztikailag igazolható kapcsolat volt kimutatható. Ennek elsősorban az az oka, hogy a suták mintája tartalmazza a testileg nem kifejlett, fél éves egyedeket is és elsődlegesen ezeknek az egyedeknek köszönhető a relatív magas korrelációs koefficiens. A fentiek alapján megállapítható, hogy míg a bakok esetében a szemlencse szárazanyag-tömegének gyarapodása egy éves korra gyakorlatilag megáll, vagy csak rendkívül kis mértékben gyarapszik, addig a suták esetében ez a növekedés, ha kismértékben is de még évekig, körülbelül 5 éves korig elhúzódik. 
Őzsuták vizsgálata során cementzónák és az orrsövény alapján RAJNIK (1977) szerint becsült kor között szoros statisztikailag igazolható kapcsolatot sikerült kimutatni. A korrelációs koefficiens értéke igen magas $(\mathrm{r}=0,8841)$, a varianciák és középértékek statisztikailag nem különböznek. Mindezek alapján megállapítható, hogy a suták estében az orrsövény vizsgálata az életkorról jól tájékoztat.

A vizsgálataim reményeim szerint hozzájárulnak az őz biológiájának jobb megismeréséhez, korbecslésének objektívebb, egzaktabb kivitelezéséhez.

\section{KÖSZÖNETNYILVÁNÍTÁS}

Elsőként néhai PROF. DR. KÖHALMY TAMÁs egyetemi tanárnak tartozom köszönettel, aki hosszú évek óta támogatta munkámat, és bölcs tanácsaival irányította szakmai tevékenységemet.

Köszönettel tartozom PROF. DR. NÁHLIK ANDRÁSnak, az Erdőmérnöki Kar dékánjának, a Vadgazdálkodási Intézet egyetemi tanárának, tudományos vezetőmnek munkámhoz nyújtott önzetlen segítségért.

Hálával tartozom PROF. DR. FARAGÓ SÁNDOR rektornak, intézetigazgató egyetemi tanárnak és DR. GERGÁTZ ELEMÉR tanszékvezető egyetemi docensnek munkámat végig kísérő segítségükért, szakmai és emberi tanácsaikért, útmutatásaikért.

Köszönöm PROF. DR. BENEDEK PÁL intézetigazgató egyetemi tanárnak, munkahelyi vezetőmnek szakmai támogatását és, hogy laboratóriumot biztosított a jelentős zaj és porképződéssel járó csiszolatpreparátumaim elkészítéséhez.

Külön köszönettel tartozom KIRÁLY ISTVÁN vadászati felügyelőnek, GICZI FERENC vadászati igazgatónak és VITÁLIS MIHÁLY vadgazdamérnök hivatásos vadásznak, akik az anyaggyüjtésben nyújtottak pótolhatatlan segítséget.

Köszönöm B. KISSNÉ DR. KELEMEN GERTRÚD tanszékvezető egyetemi docensnek, hogy lehetőséget biztosított a szárítási és tömegmérési munkák elvégzésére.

Köszönöm segítségét Bognár Gábornak, az Országos Trófeabíráló Bizottság elnökének.

Köszönettel tartozom DR. SOMOGYI ZolTánNAK, az Erdészeti Tudományos Intézet Erdőművelési és Fatermesztési Osztály tudományos osztályvezetőjének, aki a sokszor nyújtott segítséget munkám során.

Köszönöm az ELTE TTK Állatszervezettani Tanszék, a Kőzettani és Geokémiai Tanszék és a SZIE Anatómiai és Szövettani Tanszék munkatársainak, különösen DR. ZBORAY GÉZÁnak, PÁlFIA ZsolTnak, PÁlFIA ZsoltnÉnak, DR. SZABÓ CSABÁnak, FALl ANDRÁSnak és GOMBÁR GABRIELLÁnak, hogy lehetőséget biztosítottak a mikroszkópi preparátumok és a mikroszkópi fotók elkészítéséhez.

Köszönöm FODOR JÁNOSNÉ laboránsnak és NÉMETHNÉ WURM KATALINnak adminisztrátornak, hogy a mérési jegyzőkönyvek megírásával és legépelésével segítségemre voltak.

\section{IRODALOMJEGYZÉK}

1996. évi LV. törvény a vad védelméről, a vadgazdálkodásról, valamint a vadászatról.

30/1997.(IV.30.) FM rendelet.

79/2004.(V.4.) FVM rendelet

ÁBRAHÁM A. (1964): Összehasonlító állatszervezettan. Tankönyvkiadó. Budapest, 1055 p.

AITKEN, R. J. (1975): Cementum layers and tooth wear as criterion for ageing Roe deer (Capreolus capreolus). Journal of Zoology London 175: 15-28.

Almasan, H. A. (1972): Untersuchungen der Zahnstruktur zur Alterbestimmung beim Rechwild (Capreolus capreolus L.) Zeitschrift für Jagdwissenschaft 18: 222-224. 
ANDERSEN, J. \& JENSEn, D. (1972): The weight of the eye lens in European hares known age. Acta Theriologica 17: 87-92.

Angibault, J. M., Bideau, E., Vincent J. P., Quere, J. P. \& KaZRAiE (1993): Détermination de l'âge chez le Chevreuil (Capreolus capreolus L.) Test de critères morphologiques à partir d'animaux d'âge connu. Mammalia 57: 4 579-587. http://dx.doi.org/10.1515/mamm.1993.57.4.579

Ashby, K. R. \& HENRY, B. A. M. (1979): Age criteria and life expectancy of Roe deer (Capreolus capreolus) in coniferousforest in North-eastern England. Journal of Zoology, London 189: $207-220$.

BÁN I. szerk. (1986): Élőhely és trófeavizsgálat számitógéppel. Akadémiai Kiadó. Budapest, 207 p.

BARÁTH CS-NÉ (szerk.) (1996): Biometria. Mezőgazda Kiadó. Budapest, 288 p.

BLASE, R. (1960): Die Jägerprüfung. Neumann-Neudamm, Melsungen, 12. Aufl.

BLAZIS, A. S. (1971): A method of vital extraction of tooth in Capreolus capreolus for age determination. (In Russian with English summ.) Zoologicseszkij Zsurnal 50(6): 926-929.

BRIAN, R. A. (1966): Determining age of white-tailed deer from layers in cementum of molars. Journal of Wildlife Management 30(1): 197-199.

BRIEL, W. (1978): Alterbestimmung nach Zahn- und Kiefermerkmalen an Siegerländer Rechböcken und Rothirschen und Rothirschen Sauerländer Sikahirschen. Zeitschrift für Jagdwissenschaft 24(4): 169-177.

BROEKHUIZEN, S. (1971): Age determination and age composition of hare populations. Union Intern. Biol. De Giber X. Congres, Paris, pp. 477-489.

BRown, W. A. B. \& N. G. ChAPMAN, (1991): Age assessmant of red deer (Cervus elaphus) from a scoring sheme based on radiographs of developing permanent molariform teeth. Journal of Zoology London 225: 85-97. http://dx.doi.org/10.1111/j.1469-7998.1991.tb03803.x

CARTER, RICHARD J. (1998): Reassessment of Seasonality at the Early Mesolithic Site of Star Carr, Yorkshire Based on Radiographs of Mandibular Teeth Development in Red Deer (Cervus elaphus). Journal of Archaeological Science 25: 851-856. http://dx.doi.org/10.1006/jasc.1997.0230

CASTEL, R. W. (1975): Incremental growth zones in mammals and their archeological value. Kroeber Antropological Association Papers 47/48: 1-27.

Cederlund, G., KJellander, P. \& Stalfelt, F. (1991): Age determination of roe deer by tooth wearand cementum layers - test with known age material. Proceedings of XXth Congress of the IUGB, Gödöllő. pp. 587-590.

Charles, D. K., Condon, K., Cheverud, J. M. \& Buikstra, J. E. (1986): Cementum annulation and age determination in Homo sapiens I: tooth varialbility and observer error. American Journal of Physical Anthropology 71: 311-320. http://dx.doi.org/10.1002/ajpa.1330710306

ChAyen, J., Bitensky, L. \& BUTCHER, R. G. (1973): Practical histochemistry. John Wiley and Sons, London.

Condon, K., Charles, D. K., Cheverud, J. M. \& Buikstra, J. E. (1986): Cementum annulation and age determination in Homo sapiens II: estimates and accuracy. American Journal of Physical Anthropology 71: 321-330. http://dx.doi.org/10.1002/ajpa.1330710307

COY, J. P., JONES, R. T. \& TURNER, K. A. (1982): Absolute ageing of cattle from tooth sections and its relevance to archaeology. In: WiLsOn, B., Grigson, C. \& PAYNe, S. (eds.) Ageing and Sexing Animal Bones from Archaeological Sites: pp.127-140. Oxford: BAR British Series 109.

CsÁKI Á. (2002): Csontszövet. In: RÖHLICH P. (szerk.): Szövettan. Egyetemi tankönyv. Második, javított kiadás. Semmelweis Egyetem képzéskutató, Oktatástechnológiai és Dokumentációs Központ. Budapest

DAPSON, R. W. (1980): Guidelines for statistical usage in age-estimation techniques. Journal of Wildlife Management 44(3): 541-548. http://dx.doi.org/10.2307/3808001

Dellman, D. H. (1993): Textbook of veterinary histology. 4th edition. Lea and Febiger, Philadelphia.

Duglas, M. J. W. (1970): Dental cement layers as criteria of age deer, in New Zealand with emphasis on red deer, Cervus elaphus. New Zealand Journal of Science 13: 352-358.

EIDMANN, N. (1932): Alterserscheinungen am Gebiss des Rothirsches (Cervus elaphus L.). Mitt. Forstw. Forstwiss. 3: 291-341. 
ERICKSON, J. A. \& SELIGER, W. G. (1969): Efficient sectioning of incisors for estimating ages of mule deer. Journal of Wildlife Management 33: 384-388. http://dx.doi.org/10.2307/3799839

F. NAGY Gy. (1994): Biometria. Erdészeti és Faipari Egyetem, jegyzet. Sopron, 82 p.

FANCY, S. G. (1980): Preparation of Mammalia teeth for age determination by cementum layers: a review. Wildlife Society Bulletin 8 (3): 242-248.

FARAGÓ S. (1994): Vadászati állattan és etológia. Erdészeti és Faipari Egyetem, jegyzet. Sopron, 271 p.

FARAGÓ S. (2002): Vadászati állattan. Mezőgazda Kiadó, Budapest.

FARAGÓ S. \& NÁHLIK A. (1997): A vadállomány szabályozása. Mezőgazda Kiadó. Budapest, 315 p.

FEHÉR Gy. (1980): A háziállatok funkcionális anatómiája. Mezőgazdasági Kiadó. Budapest, 910 p.

FELEK Zs. (1987): Az öz kormeghatározása a fog cementállományának növekedési vonalai alapján. Diplomamunka, GATE, Gödöllö.

FISHER, H. D. \& MACKENZIE, B. A. (1954): Rapid preparation of tooth sections for age determinations. Journal of Wildlife Management 18: 535-537. http://dx.doi.org/10.2307/3797096

GÁLNÉ SólYMOS K. (1997): Pásztázó elektronmikroszkópia és elektronsugaras mikroanalízis. Oktatási segédanyag. ELTE Kőzettan-Geokémiai Tanszék, Budapest.

GILBERT, F. F. (1966): Aging white-tailed deer by annuli in the cementum of the first incisor. Journal of Wildlife Management 30 (1): 200-202 http://dx.doi.org/10.2307/3797906

GORDON, B. C. (1988): Of men and Reindeer herds in French Magdalenian Prehistory. Oxford: BAR Int. Ser. 390.

GoRdON, B. C. (1993): Archaeological Tooth and Bone Seasonal Increments: The Need of Standardized terms and Techniques. Archaeozoologia 5(2): 9-16.

GRUE, H. E. (1976): Non-seasonal incremental lines in tooth cementum of domestic dogs (Canis familiaris L.) of known age. Danish Review of Game Biology 10(2): 2-8.

GRUE, H. E. \& JENSEN, B. (1973): Annular structures in canine tooth cementum in red foxes (Vulpes vulpes L.). Danish Review of Game Biology 8(7): 3-12.

GRUE, H. E. \& JENSEN, B. (1976): Annualar cementum structures in canine teeth in Arctic foxes (Alopex lagopus L.) from Greenland and Denmark. Danish Review of Game Biology 10(3): 3-12.

GRUE, H. E. \& JENSEN, B. (1979): Review of the formation of incremental lines in tooth cementum of terrestrial mammals. Danish Review of Game Biology 11(3): 1-48.

GuzSAL, E. (1981): Háziállatok szövettana. Mezőgazdasági Kiadó. Budapest, 459 p.

Habermehl, K. H. (1985): Die Altersbestimmung bei Haustieren, Pelztieren und beim jagdbaren Wild. Berlin \& Hamburg: Paul Parey.

HARRIS, S. (1978): Age determination in the Red fox (Vulpes vulpes) - an evaluation of technique efficiency as applied to sample of suburban foxes. Journal of Zoology London 184: 91-117.

Hewison, A. M. J., Vincent, J. P., Angibault, J. M., Van Laere, G. \& Gaillard, J. M. (1999): Tests of estimation age from tooth wear on roe deer of known age: variation within and among populations. Canadian Journal of Zoology 77: 58-67. pp. http://dx.doi.org/10.1139/z98-183

HILLSON, S. (1986): Teeth. Cambridge: Cambridge University Press.

HILlSON, S. \& BOND, S. (1996): A scanning electron microscope study of bone, cementum, dentine, and enamel. In: BELl, M., FOWLER, P. J. \& HILLSON, S. W. (eds.): The experimental earth project, 1960-1992. CBA Research Report, York, Council of British Archaeology: pp. 185195. English Heritage.

HoLlósi G. (1995): Funkcionális állatanatómia II. Nemzeti Tankönyvkiadó. Budapest, 426 p.

HRABE, V. \& KoUBEK, P. (1987): A comparison of some ageing methods in male Roe deer (Capreolus capreolus). Folia Zoologica 36(1):1-12

HusvéTH F. (2000): A gazdasági állatok élettana az anatómia alapjaival. Mezőgazda Kiadó. Budapest $653 \mathrm{p}$.

KAY, M. (1974): Dental annuli age determination on white-tailed deer from archaeological sites. Plains Anthropologist 19: 224-227.

KIEDORF, U. \& BECLNER, J. (1997): Mineralization and wear of mandibular first molars in red deer (Cervus elaphus) of known age. Journal of Zoology London 241: 135-143.

KISZELY GY. \& BARKA T. (1958): Gyakorlati mikrotechnika és hisztokémia. Medicina Könyvkiadó, Budapest. 
Klein, P. G., C. Wolf, L. G. Freeman \& Allwarden, K. (1981): The use of dental crown heights for constructing age profiles of red deer and similar species in archaeological samples. Journal of Archaeological Science 8: 1-32. http://dx.doi.org/10.1016/0305-4403(81)90010-8

Klevezal, G. A. (1996): Recording Structures of mammals. Determination of Age and Reconstruction of Life History. English Translation. Rotterdam: A. A. Balkema.

KleVeZAL, G. A. \& KLEINENBERG, S. E. (1967): Age determination of mammals from annual layers in teeth and bone (Russian, translated into English 1969).

KÖHALMY T. (1999): Korbecslések. Szarvastól a siketfajdig. Nimród Alapítvány. Budapest, 110 p.

KovÁCS G. (1983): Survival pattern in adult European hares. Acta Zoologica Fennica 174: 69-70.

KOVÁCS G. \& FELEK Z. (1991): Reliability of the cementum annuli count and the hunter's age determination in the roe deer. Proceedings of XXth Congress of the IUGB, Gödöllö. 587-590. pp.

KovÁcs Gy. \& HeltAy I. (1993): A mezeinyúl. Ökológia, gazdálkodás, vadászat. Hubertus Bt. és Magyar Mezőgazdaság Kft. Budapest, 177 p.

KRUTSAY M. (1980): Szövettani technika. Medicina Könyvkiadó, Budapest.

KRUTSAY M. (1999): Patológiai technika. Medicina Könyvkiadó, Budapest.

KÜHNEL, W. (1997): Szövettan. SH orvosi atlasz. Springer Hungarica Kft. Budapest, 521 p.

KvaAl, S. I., Solheim, T. \& BJerketvedT, D. (1996): Evaluation of Preparation, Staining and Microscopic Techniques for counting incremental lines in cementum of Human Teeth. Biotechnic and Histochemistry 71(4): 165-172. http://dx.doi.org/10.3109/10520299609117155

LAWS, R. M. (1952): A new method of age determination for mammals. Nature 169: 972-973.

LESSON, R. C. , LESSON, T. S. \& PAPARO, A. A. (1985): Textbook of histology. 5th edition, W.B. Saunders Company, Philadelphia.

LIEBERMAN, D. E. (1993): Life history variables preserved in dental cementum microstructure. Science 261: 1162. http://dx.doi.org/10.1126/science.8356448

LIEBERMAN, D. E. (1994): The biological basis for seasonal increments in dental cementum and their application to archelogical research. Journal of Archelogical Science 21: 525-539. http://dx.doi.org/10.1006/jasc.1994.1052

Lieberman, D. E., Deacon, T. W. \& MEAdow, R. H. (1990): Computer image enhancement and analysis of cementum increment as applied to teeth of Gazella gazella. Journal of Archaeological Science 17: 519-533.http://dx.doi.org/10.1016/0305-4403(90)90033-2

LIEBERMAN, D. E. \& MEADOW, R. H. (1992): The biology of cementum increments (with an archaeological application). Mammal Review 22(2): 57-77. http://dx.doi.org/10.1111/j.13652907.1992.tb00120.x

LOCKARD, G. R. (1972): Further studies of dental annuli for aging white-tailed deer. Journal of Wildlife Management 36(1): 46-55. http://dx.doi.org/10.2307/3799187

LORD, R.D. (1959): The lens as an indicator of age in Cottontail Rabbits. Journal of Wildlife Management 23: 358-360. http://dx.doi.org/10.2307/3796900

LOW, W. A. \& MCT. COWAN, I.. (1963): Age determination of deer by annular structure of dental cementum. Journal of Wildlife Management 27(3): 466-471. http://dx.doi.org/10.2307/3798521

LOWE, V. P. W. (1967): Teeth as indicators of of age with special reference to red deer (Cervus elaphus) of known age from Rhum. Journal of Zoology London 152: 137-153.

MARINGGele, F. J. (1979): Alterbetimung beim Reh (Capreolus capreolus L.) und beim Rothirsch (Cervus elaphus L.) mit Hilfe der Trockengewichtsbestimmung der Augenlinse. Zeitschrift für Jagdwissenschaft 24: 178-182.

MAROSÁN M. (1999): A gímszarvas korbecslési módszereinek összehasonlitó értékelése. Szakdolgozat. Soproni Egyetem. Sopron

MAROSÁN M. (2000): Korbecslési vizsgálatok gímszarvasnál. Soproni Egyetem Tudományos Közleményei 46: 145-159. pp.

MARosán M. (2001a): A gímszarvas egyes korbecslési módszereinek értékelése. Vadbiológia 8: 4348. pp.

MAROSÁN M. (2001b): Az öz [Capreolus capreolus (L.) 1758] egyes korbecslési módszereinek összehasonlitó értékelése. Diplomamunka. NYME Mezőgazdaságtudományi Kar Mosonmagyaróvár. 
MAROSÁN M., GÁL J. \& NÁHLIK A. (2003): Életkorbecslési vizsgálatok tapasztalatai őznél. Kárpátmedencei Biológiai Szimpózium 2003. Budapest.

MAROSÁN, M. \& GergátZ, E. (2001): Az őz (Capreolus capreolus /L./ 1758) egyes korra utaló morfológiai bélyegeinek vizsgálata. Acta Agronomica Óváriensis 43(2): 113-126.

MAROSÁN M. GÁL J. \& KIRÁLY I. (2002): Data relating to the body measurement of female roe deer in Hungary. Acta Agronomica Óváriensis 44(2): 141-147.

MAROSI S. \& SOMOGYI S. (szerk.) (1990): Magyarország kistájainak katasztere. MTA Földtudományi Kutató Intézet, Budapest.

MAYHew, D. F. (1978): Age Structure of a Sample of Subfossil Beavers (Castor fiber L.). In: BUtLer, P. M. \& JOYSEY, K. A. (eds.): Development, Function and Evolution of Teeth. London: Academic Press.

MCEwAn, E. H. (1963): Seasonal annuli in the cementum of teeth of Barren Ground Caribou. Canadian Journal of Zoology 41: 111-113. http://dx.doi.org/10.1139/z63-012

MEÁK G. \& SzEDERJEI Á. (1957): Adatok az elejtett őz korának meghatározásához. Erdészeti Kutatások 1957(3-4): 267-274.

MiLlER, F. L. (1974): Age determination of caribou by annulation in dental cementum. Journal of Wildlife Management 38(1): 47-53. http://dx.doi.org/10.2307/3800199

MitChELL, B. (1963): Determination of age in Scottish red deer from growth layers in dental cement. Nature 198: 350-351. http://dx.doi.org/10.1038/198350a0

MitChELL, B. (1967): Growth layers in dental cement for determining the age of red deer (Cervus elaphus L.). Journal of Animal Ecology 36: 279-293. http://dx.doi.org/10.2307/2912

MONKS, G.G. \& ROBERT J., (1993): Estimating season of death from growth increment data: a critical review. Archaeozoology 5(2): 17-40.

MORRIS, P. (1972): A review of mammalian age determination methods. Mammal Review 2: 69-104. http://dx.doi.org/10.1111/j.1365-2907.1972.tb00160.x

MÜLlER-UsING, D. (é.n.). Rotwildalter-Merkblatt. Deutschen Jagdschutz-Verbandes.

NAGY E. \& PUSKÁS I. (1977): A fácán életkorának és koreloszlásának vizsgálata Magyarországon. Nimród Fórum 1977(10): 23-25.

NAGY E. \& SZÉKY P. (1995): Vadászható és védett vadfajainkról. Nimród Alapítvány. Budapest, 225 p.

NÁHLIK A. (1996): Trófeakezelés és bírálat. Soproni Egyetem, jegyzet. Sopron, 114 p.

NEHRING, A. (1903): Altersbestimmung von Reh- und Rotwild. Wild und Hund.

NÉMETH A. \& L. KISS A. (2002): Tápcsatorna. In: RÖHLICH P. (szerk.): Szövettan. Egyetemi tankönyv. Második, javított kiadás. Semmelweis Egyetem képzéskutató, Oktatástechnológiai és Dokumentációs Központ. Budapest

PASCAL, M. \& KovÁCS G. (1983): La determination de l'âge individuel chez le lièvre européen par la technique squelettochronologique. Rev. Ecol. 37: 173-186.

PÉPIN, D. (1973): Recherche d'âge chez le liévre, Lepus europeus. Ann Zool. Ecol. Anim. 5: 271-281.

PÉPIN, D. (1974): Mise an point de techniques pour l'étude de populations de liévre. Bull. Office National de la Chasse 2: 77-119.

PIKe-TAY, A. (1991): Red Deer Hunting in the Upper Paleolithic of South-West France: A Study in Seasonality. Oxford: BAR Int. Ser. 569.

PIKE-TAY, A. (1995): Variability and Synchrony of Seasonal Indicators in Dental Cementum Microstructure of the Kaminuriak Caribou Population. Archaeofauna 4: 273-284.

PRIOR, J. (1968): The Roe Deer of Caranbone Chase. London: Oxford University Press

QUIMBY, D. C. \& GAAB, J. E. (1957): Mandibular dentition as an age indicator in Rocky Mountain elk. Journal of Wildlife Management 21: 435-451. http://dx.doi.org/10.2307/3796676

RAJNIK F. (1977): Új módszer az őz kormeghatározására. Nimród Fórum 1977(12): 20-21.

RANSOM, A. B. (1966): Determining the age of white-tailed deer from layers in cementum of molars. Journal of Wildlife Management 30(1): 197-199. http://dx.doi.org/10.2307/3797905

RICE, L. A. (1980): Influence of irregular dental cementum layers on aging deer incisors. Journal of Wildlife Management 44(1): 266-267. http://dx.doi.org/10.2307/3808384

RIECK, W. (1970): Alter und Gebissabnutzung beim Rehwild. Zeitschrift für Jagdwissenschaft 16: 17. 
RobinetTe, W. L., JONES, D. A., Rogers, G. \& GASHWILER, J. S. (1957): Notes on tooth development and wear for Rocky Mountain mule deer. Journal of Wildlife Management 21(2): 134-153. http://dx.doi.org/10.2307/3797579

RöHLICH P. (2002): A szövetek vizsgálatának módszerei. In: RöHLICH P. (szerk.): Szövettan. Egyetemi tankönyv. Második, javított kiadás. Semmelweis Egyetem képzéskutató, Oktatástechnológiai és Dokumentációs Központ. Budapest

RoMEIS, B. (1968): Mikroskopische Technik. R. Oldenbourg Verlag, München - Wien.

SAVILle, J. \& BeAtTIE, O. W. (1983): Analysis of Dental Annuli in Muskoxen (Ovibos moschatus) as an Aid to the Determination of Archaeological Site Seasonality. Canadian Journal of Archaeology 3: 123-129.

SCHEFFER, V. B. (1950): Growth layers on the teeth of Pinnipedia as an indication of age. Science 112: 309-311. http://dx.doi.org/10.1126/science.112.2907.309-a

Sergeant, D. E. \& PimlotT, D. H. (1959): Age determination in moose from sections of incisor teeth. Journal of Wildlife Management 23(3): 315-321. http://dx.doi.org/10.2307/3796891

SEVERINGHAUS, C. W. (1949): Tooth development and wear as criteria of age in white-tailed deer. Journal of Wildlife Management 13: 195-216. http://dx.doi.org/10.2307/3796089

SoHN, A. J. (1968): An evaluation of the dental annuli technique for determining age of white-tailed deer in Iowa. Proc. Iowa Acad. Sci. 74: 72-77.

Sigrid, I. K., SOlHEIM, T. \& BJERKEVEDT, D. (1996): Evaluation of Preparation, staining and microscopic techniques for counting incremental lines in cementum of human teeth. Biotechnic and Histochemistry 71(4): 165-172.

SPINAGE, C. A. (1976): Incremental cementum lines in the teeth of tropical African mammals. Journal of Zoology London 178: 117-131.

STALLIBRASS, S. (1982): The use of cementum layers for absolute ageing of mammalian teeth: a selective review of the literature, with suggestions for further studies and alternative applications. In: Wilson, B., Grigson, C. \& PAYNE, S. (eds.): Ageing and Sexing Animal Bones from Archaeological Sites: pp.109-126. Oxford: BAR British Series 109.

STEN, S. A. (1989): A method of age determination on archaeological and modern cattle (Bos taurus) by counting of tooth annuli in the cementum. Laborativ Arkeologi 5:195-199.

STONEBERG, R. P. \& JONKEL, C. J. (1966): Age determination of black bears by cementum layers. Journal of Wildlife Management 30: 411-414. http://dx.doi.org/10.2307/3797828

SZABIK, E. (1973): Age estimation of roe-deer from different hunting-grouns of South-Eastern Poland. Acta Theriologica 18, 12: 223-236. http://dx.doi.org/10.4098/AT.arch.73-14

SzEDERJEI Á. (1940a): Kormeghatározás: Az öznél. Erdészeti Lapok 79: 374-385.

SzEDERJEI Á. (1940b): Kormeghatározás: Az őznél (Befejező közlemény). Erdészeti Lapok 79: 427432.

SZEDERJEI Á. (1955): Újabb módszerek az elejtett őz kormeghatározására. Erdészeti Kutatások 1955 (3): $135-147$.

SZEDERJEI Á. (1959): Öz. Mezőgazdasági Kiadó. Budapest, 194 p.

SZEDERJEI Á. (1960): Szarvas. Mezőgazdasági Kiadó. Budapest, 226 p.

SZÉKY P. (1979): Vadászati Állattan II. GATE, jegyzet. Gödöllő, 342 p.

SZIDNAi L. (1978): Trófeák kikészitése és bírálata. Mezőgazdasági Kiadó. Budapest, 202 p.

SZIKOSSY I., MAROSÁN M. \& PAPP I. (2003): A fog cementállományának vizsgálata történeti embertani anyagon. Kárpát-medencei Biológiai Szimpózium 2003. Budapest.

SzUnYoGHY J. (1963): A magyarországi szarvas. Das ungarische Rotwild. (Kandidátusi értekezés), Magyar Természettudományi Múzeum, Budapest. 193 p.

THOMAS, D. C. \& BANDY, P. J. (1973): Age determination of wild black-tailed deer from dental annulations. Journal of Wildlife Management 37(2): 232-235. http://dx.doi.org/10.2307/3798909

UECKERMANN \& SCHOLZ, H. (1971): Zur Zahnentwicklung und Altersschätzungbeim Sikawild (Sika nipon). Zeitschrift für Jagdwissenschaft 17: 49-52.

VARGA T. (1996): Az őzbak kormeghatározása. Nimród 84(4): 11-12 pp.

VARGHA A. (2000): Matematikai statisztika pszichológiai, nyelvészeti és biológiai alkalmazásokkal. Pólya Kiadó, Budapest.

VíGH B. \& KONDICS L. (1991): Összehasonlító szövettan. Tankönyvkiadó. Budapest, 377 p. 
WhITE, G. (1974): Age determination of roe deer (Capreolus capreolus) from annual growth layers in the dental cementum. Journal of Zoology London 174: 511-516. pp.

WolfE, M. L. (1969): Age determination in moose from cemental layers of molar teeth. Journal of Wildlife Management 33(2): 428-461. http://dx.doi.org/10.2307/3799849

Wood, A. J., COWAN, MCT. \& NORDAN, H. C. (1962): Periodicity of growth in ungulates as shown by deer of the genus Odocoileus. Canadian Journal of Zoology 40(4): 593-603. http://dx.doi.org/10.1139/z62-053

\section{Táblázatok jelmagyarázata}

Cement z. kor: cementzónák alapján becsült kor; x: átlag; s: szórás; r: számított korrelációs koefficiens; $\mathrm{r}^{*}$ : kritikus korrelációs koefficiens; $\mathrm{r}^{2}$ : determinációs koefficiens; f.t.: a függvény típusa; lin.: lineáris; par.: másodfokú parabola; log.: logaritmus 